Democratic Republic of the Congo: 2001 Article IV Consultation and Discussions on Staff-Monitored Program-Staff Report; Staff Supplement; Public Infomation Notice on the Exceutive Board Discussion; and Statement by the Authorities of the Democratic Republic of the Congo 


\section{Democratic Republic of the Congo: 2001 Article IV Consultation and Discussions on Staff-Monitored Program-Staff Report; Staff Supplement; Public Information Notice on the Executive Board Discussion; and Statement by the Authorities of the Democratic Republic of the Congo}

Under Article IV of the IMF's Articles of Agreement, the IMF holds bilateral discussions with members, usually every year. In the context of a combined discussion of the 2001 Article IV consultation with the Democratic Republic of the Congo and staff-monitored program, the following documents have been released and are included in this package:

- the staff report for the 2001 Article IV consultation, prepared by a staff team of the IMF, following discussions that ended on May 16, 2001, with the officials of the Democratic Republic of Congo on economic developments and policies. Based on information available at the time of these discussions, the staff report was completed on June 20,2001 . The views expressed in the staff report are those of the staff team and do not necessarily reflect the views of the Executive Board of the IMF;

- a staff supplement of July 12, 2001, updating information on recent economic developments;

- the Public Information Notice (PIN) summarizing the views of the Executive Board as expressed during the July 13, 2001, Executive Board discussion of the staff report that concluded the Article IV consultation;

- a statement by the authorities of the Democratic Republic of the Congo.

The policy of publication of Article IV staff reports and PINS allows for the deletion of marketsensitive information.

The document listed below will be separately released.

Selected Issues Paper and Statistical Annex

The policy of publication of staff reports and other documents by the IMF allows for the deletion of market-sensitive information.

To assist the IMF in evaluating the publication policy, reader comments are invited and may be sent by e-mail to Publicationpolicy@imf.org.

Copies of this report are available to the public from

International Monetary Fund - Publication Services

70019 th Street, N.W. - Washington, D.C. 20431

Telephone: (202) 6237430 - Telefax: (202) 6237201

E-mail: publications@imf.org • Internet: http://www.imf.org

Price: $\$ 15.00$ a copy

International Monetary Fund

Washington, D.C. 


\section{INTERNATIONAL MONETARY FUND \\ DEMOCRATIC REPUBLIC OF THE CONGO}

\section{Staff Report for the 2001 Article IV Consultation and Discussions on a Staff-Monitored Program}

Prepared by the African Department

(In consultation with the Fiscal Affairs, Legal, Monetary and Exchange Affaits, Policy Development and Review, Statistics, and Treasurer's Departments)

Approved by G. E. Gondwe and S. Kashiwagi

June 20, 2001

Contents Page

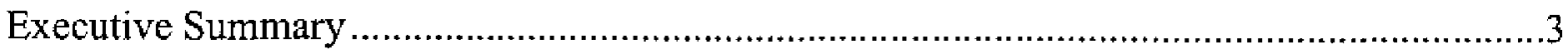

I. Introduction … 6

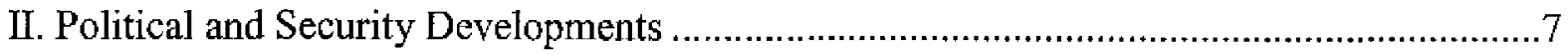

III. Modalities Concerning the Clearance of Arrears with the Fund …ㄴ..

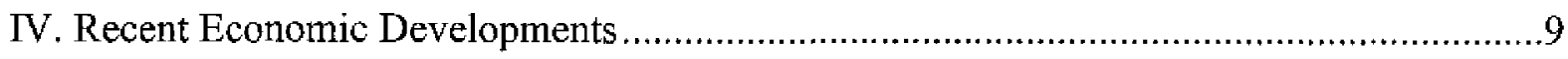

V. Policy Discussions and the Fund Staff-Monitored Program …………………………........15

A. Fiscal Policy . . .

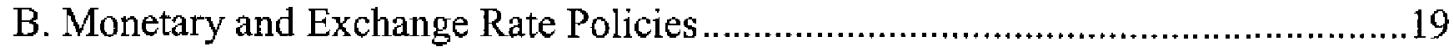

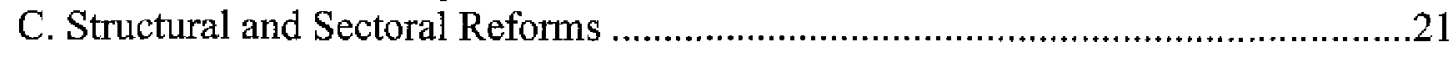

D. Promotion of Transparency and Good Governance

VI. Staff Appraisal . .

Tables

1. Selected Economic and Financial Indicators, 1996-2001 ……………………… 27

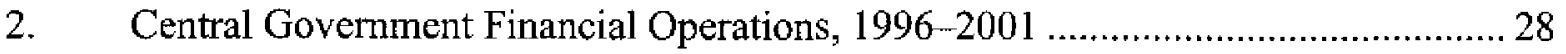

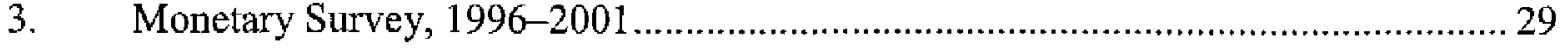

4. Balance of Payments, 1996-2001 _- 30

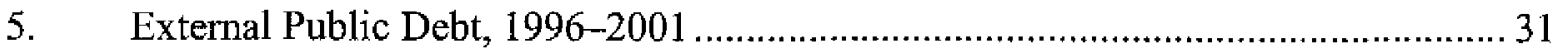




\section{Figures}

1. Fiscal Deficit, Money, Prices, and Exchange Rates, 1998-2001 _........................ 32

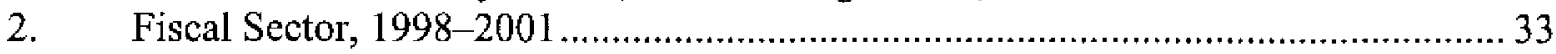

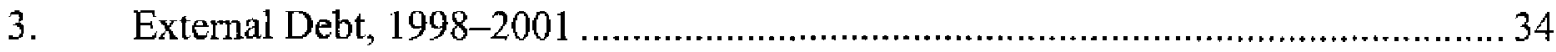

4. Exchange Rate Indices, January 1996-March 2001 ……

Text Boxes

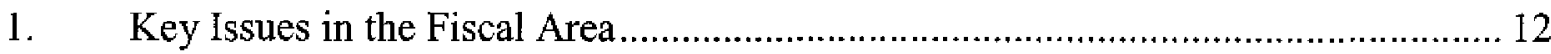

2. Banking Sector Issues _.............

Appendices

I. Letter of Intent

Attachment I: Memorandum on Economic and Financial Policies .............. 38

Table 1. Fiscal Measures Planned for 2001 ................................. 47

Table 2. Technical Assistance Requirements in the Fiscal Area ...... 48

Table 3. Prior Actions ...................................................... 49

Table 4. Quarterly Quantitative Indicators ..............................5 50

Table 5. Structural Performance Benchmarks …............................ 51

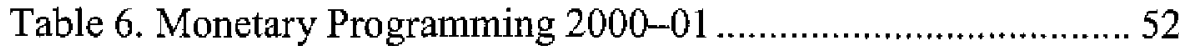

Table 7. Monthly Treasury Cash-Flow Plan 2001 .......................... 53

Attachment II: Technical Memorandum of Understanding ........................ 54

Annex I: Guidelines on Performance Criteria

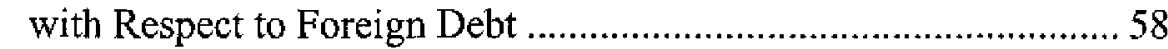

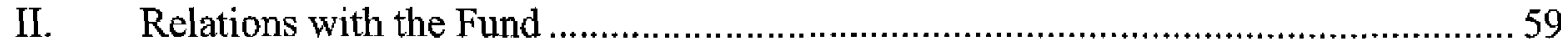

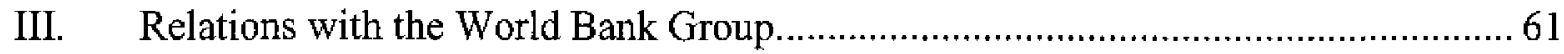

IV. Statistical Issues ........................ 


\section{EXECUTIVE SUMMARY}

\section{Recent political and economic developments}

- Economic mismanagement, political turmoil, and a prolonged rundown in the economic and social infrastructure since the early $1990 \mathrm{~s}$, combined with the effects of the war that erupted in August 1998, have created a vicious circle of hyperinflation, continued depreciation of the currency, increasing dollarization, financial disintermediation, lack of saving, falling output, and generalized impoverishment of the population with the concomitant spread of diseases like HIV/AIDS.

- Under the new President, Joseph Kabila, the political and security situation in the Democratic Republic of the Congo (DRC) has been improving since early 2001, thanks to the reactivation of the Lusaka cease fire agreement, involvement of the United Nations, and the enhancement of the inter-Congolese dialogue. In addition, the authorities have started the process of reconstruction and revitalization of the economy through macroeconomic stabilization, and by liberalizing the Congolese economy and opening it up to the rest of the world. In this context, understandings have been reached on a Fund staff-monitored program (SMP).

\section{The SMP (June 2001-March 2002)}

- To address the alarming economic, financial and social situation, the authorities' program contains a critical mass of bold and front-loaded adjustment measures, aiming principally at breaking hyperinflation, stabilizing the economic situation, and laying the foundation for a restoration of growth and reconstruction. To achieve these objectives, the macroeconomic policies envisaged in the program include, inter alia:

- A restrained budgetary policy, centered around strict adherence to a monthly treasury cash plan;

- A prudent monetary policy consistent with the objective of breaking hyperinflation. Central to the successful implementation of monetary policy will be the restoration of the independence of the Central Bank of the Congo (BCC);

- The implementation of a floating exchange rate system. On May 26, the new system was put in place, thereby unifying the existing official and parallel market rates.

Far-reaching structural reforms, with the World Bank taking the lead, would pave the way for a significant reduction in price distortions, a strengthening of the banking sector, improvement of economic security, and liberalization of the economy. 


\section{Looking beyond the program}

- The authorities intend, in line with progress to securing peace, to put in place in due course a broader strategy for post-conflict reconstruction. They see the SMP as a critical first step toward restoring economic stability to help establish the conditions for a revival of economic activity and a reduction of poverty. A comprehensive postconflict strategy would address the DRC's demobilization, reconstruction, and reintegration needs and the rebuilding of administrative and institutional capacity (beyond the immediate needs of the SMP).

- The DRC has been in continuous arrears with the Fund since 1990 (the stock at endApril was SDR 392 million or 135 percent of its current quota and 74 percent of what its quota would be under the Eleventh Review of Quotas). The authorities are keen to normalize relations with the Fund and recognize the need to make progress toward clearance of arrears to the Fund in the course of the SMP. Clearance of all of DRC's arrears to the Fund is likely to necessitate arranging a bridge loan (a bilateral creditor has already agreed in principle to do so, if performance under the SMP is sufficiently strong).

\section{Issues stressed in the staff appraisal}

- The authorities believe that the conditions are now ripe for adopting and implementing an interim program that could be monitored by the Fund staff during the period from June 2001 to March 2002. The staff concurs with this assessment, but stresses that successful implementation of the SMP will depend critically on continued progress toward peace, the timely support of the international community, including in the very short term, and the strengthening of government policy coordination, as well as the effective monitoring of the program through the interministerial economic and financial policy monitoring committee (ECOFIN).

- The strengthening of the control and monitoring of all expenditure, including "sovereign" and security related expenditure, will be key to the success of the program. Therefore, the authorities are urged to rigorously implement the monthly treasury cash flow plan.

- In order not to endanger the objective of breaking hyperinflation, the authorities would have to resist any pressure for further wage increases, following the salary increases of late May to alleviate the social impact of price adjustment measures, in particular those concerning transportation costs.

- The staff welcomes the new statutes of the BCC that will provide the legal basis for its regained independence and that will be published in June. The staff stresses that $\mathrm{BCC}$ advances to the government will need to be strictly limited in conformity with the new statutes and the monetary program. 
- A solid track record under the SMP could be followed by a program under the Poverty Reduction and Growth Facility (PRGF), underpinned by an interim poverty reduction strategy paper (I-PRSP). Steady implementation of the PRGF should allow the DRC to seek debt relief under the Heavily Indebted Poor Countries (HIPC) framework, with a view to reducing its heavy debt service burden to sustainable levels. 


\section{INTRODUCTION}

1. A mission visited Kinshasa during May 2 16, 2001, ${ }^{1}$ to conduct discussions for the 2001 Article IV consultation and negotiate a Fund staff-monitored program (SMP). ${ }^{2}$ The mission met with His Excellency President Joseph Kabila, most ministers of the newly appointed government, including the Minister of Economy, Finance, and the Budget, Mr. Matungulu, and the Governor of the Central Bank of the Congo (BCC), Mr. Masangu. The mission also met with representatives of civil society, including trade unions and the business sector, and the international community. The last Article IV consultation with the Democratic Republic of the Congo (called Zaïre at the time) was concluded in March 1996 (SM/96/34; 2/7/96). The Democratic Republic of the Congo (DRC) has continued to avail itself of the transitional arrangements under Article XIV. It is on the standard 12-month consultation cycle.

2. As agreed during a meeting between the Managing Director and President Kabila on February 1, 2001, a mission visited Kinshasa from February 28 to March 12, 2001, to take stock of the situation and initiate discussions on a comprehensive macroeconomic framework that could lay the basis for an SMP aimed at stabilizing the economic situation, restoring economic growth, and initiating the process of reconstruction. At that time, the President stressed the willingness of the authorities to normalize the DRC's relations with the Fund, and to reach understandings on an interim program that could be monitored by the staff. The mission noted that there had been a marked turnaround in the attitude of the authorities, as evidenced by their strong commitment to liberalize and open up the economy, and break hyperinflation. ${ }^{3}$

${ }^{1}$ The mission comprised Messrs. Clément (Head), Gons and Akitoby (all AFR), Fournel (FAD), Dicks-Mireaux and Staines (PDR), and Ms. Ng Choy Hing (Staff Assistant) (AFR). World Bank staff participated in the mission. Two Fund technical assistance missions in the areas of fiscal revenue and the exchange rate system, respectively, as well as a World Bank. mission to discuss structural and sectoral issues, overlapped with the mission. Mr. Kpetigo, Assistant to the Executive Director, participated in some of the policy discussions.

${ }^{2}$ The letter of intent and the memorandum on economic and financial policies are included in Appendix I.

${ }^{3}$ The February-March 2001 mission comprised Messrs. Clément (Head), Youm, Gons, Akitoby, and Samaké (Research Assistant) (all AFR), Dicks-Mireaux (PDR), Corfmat and Fournel (FAD), and Durand (MAE). World Bank staff participated in the mission. Mr. Kudiwu, Assistant to the Executive Director, participated in some of the policy discussions. The mission left with the authorities a detailed aide-memoire that provided a diagnosis of the economic situation and proposed key elements of a comprehensive macroeconomic policy framework. 
3. The DRC has been in continuous arrears to the Fund since November 1990. On September 6, 1991, it was declared ineligible to use the general resources of the Fund, and a declaration of noncooperation was issued on February 14, 1992. The voting and related rights of the DRC in the Fund were suspended on June 2, 1994. On March 18, 1998, the Executive Board decided that, at the next review of the DRC's overdue financial obligations, the Fund would consider adoption of a decision providing for the initiation of the procedure of compulsory withdrawal from the Fund unless the member had resumed cooperation with the Fund. In light of the unsettled political and security situation and the limited information available on economic developments and policies, the Executive Board subsequently decided on several occasions to postpone the postsuspension review of the DRC's overdue financial obligations to the Fund. On June 4, 2001, the Board once again decided to postpone the review for six months, or until the next Article IV consultation with the DRC, whichever was earlier (EBS/01/75; 5/17/01).

4. Summaries of the DRC's relations with the Fund and the World Bank Group are presented in Appendices II and III, respectively. Fund and World Bank staff have continued to cooperate closely on the DRC. As indicated above, World Bank staff participated in the March and May 2001 missions. The World Bank is assisting the authorities in developing a strategy in the structural and sectoral areas and is in the process of preparing a Transitional Support Strategy, which is expected to be presented to its Board in mid-July 2001.

5. The statistical apparatus has been severely affected by years of neglect and war through the loss of qualified staff, equipment, and records. Although the authorities provide the core minimum data to the Fund and publish available data, their coverage, quality, and timeliness need to be improved, especially in the areas of national accounts, public finance, and balance of payments statistics. Social data are severely limited (Appendix IV).

\section{Political and Security Developments}

6. After years of turmoil and war, the political and security situation in the DRC has been improving since early 2001, thanks to the reactivation of the Lusaka cease-fire agreement, United Nations (UN) involvement, and the enhancement of the inter-

Congolese dialogue. President Kabila has consistently stated his commitment to restore peace and enforce the terms of the Lusaka agreement. Following his visit to the $\mathrm{UN}$ in February 2001, the Security Council demanded that all troops in the DRC withdraw 9 miles from frontline positions within two weeks from March 15. This was to allow the deployment of UN military observers and support troops to monitor a cease-fire. According to UN statements, the withdrawal of troops has been on schedule, and the cease-fire so far has been generally holding. A delegation of 15 members of the UN Security Council visited Kinshasa on May 18 to take stock of the situation. In late May, Uruguayan troops began reopening and policing traffic on the Congo River, a vital link in the country's transportation system. The Security Council hopes not only to encourage momentum for the pullback of troops but also to win approval of African governments for an international conference on the economic and 
political development of the Great Lakes region. An important complicating factor in this respect is the continued plundering of the DRC's natural resources.

7. At the invitation of President Kabila, the UN-appointed facilitator, Sir Ketumile Masire, former President of Botswana, visited Kinshasa to help with the preparations for the inter-Congolese dialogue. A new, reform-minded government was appointed on April 14, 2001, and on May 18, 2001, a presidential decree was signed liberalizing political activities. The authorities believe that conditions are now ripe for adopting and implementing an interim program that can be monitored by the staff. The staff concurs with this view but would stress that successful implementation of the SMP will depend critically on continued progress toward peace.

\section{Modalities Concerning the Clearance of ARRears with the Fund}

8. The SMP, which covers the period from June 2001 to March 2002, provides the DRC with the opportunity to establish a strong track record that could lead to the clearance of arrears with the Fund, and that could be followed by a program under the Poverty Reduction and Growth Facility (PRGF), underpinned by an Interim Poverty Reduction Strategy Paper (I-PRSP). A solid track record under the SMP would also help provide assurances that the country will not fall back into arrears with the Fund. Steady implementation of the PRGF arrangement should allow the DRC to seek debt relief under the Initiative for Heavily Indebted Poor Countries (HIPC) framework, with a view to reducing its heavy debt burden to sustainable levels.

9. The authorities recognize the need to make progress toward clearance of arrears to the Fund during the course of the SMP (June 2001-March 2002). ${ }^{5}$ In light of this, they have agreed to deposit a monthly amount of SDR 100,000 in an account of the DRC held with the Bank of International Settlements. ${ }^{6}$ These deposits will continue to be part of the DRC's international reserves until their eventual use, and will be monitored by the Fund.

Stabilization of the DRC's arrears to the Fund would have implied annual payments of about SDR 12.0 million, or about SDR 1.0 million a month-which is relatively high given the low level of gross international reserves (US $\$ 52$ million at end-2000, or 2.2 weeks of imports). The staff has been guided by the Board's readiness to accept reduced payments by a post-

\footnotetext{
${ }^{4}$ As reported to the UN Security Council in May 2001 by the Panel of Experts on the Illegal Exploitation of Natural Resources and other Forms of Wealth of the DRC.

${ }^{5}$ The DRC is not eligible for the rights accumulation approach as it did not have protracted arrears with the Fund at end-1989, when the Fund's strengthened cooperative strategy on arrears (and the rights approach) was formulated.

${ }^{6}$ Certain other international financial institutions may ask the DRC for the opening of similar accounts.
} 
conflict member in arrears, in keeping with the member's debt service capacity, provided that the member is judged to be cooperating and that all other multilaterals to which the member is in arrears take at least comparable action (EBS/99/46; 3/13/99). The DRC's arrears to the Fund amounted to SDR 392 million as of end-April 2001, equivalent to about 135 percent of its current quota and 74 percent of what its quota would be under the Eleventh General Review of Quotas (SDR 533 million, compared to the current quota of SDR 291 million under the Eighth General Review of Quotas). Clearance of the DRC's arrears to the Fund is likely to necessitate arrangement of a bridge loan to a successor PRGF arrangement. ${ }^{7}$ It is envisaged that access under the successor arrangement would provide up-front resources sufficient to cover repayment of the bridge loan. This would be possible under average PRGF access limits. Additional program assistance would be needed to provide balance of payments support on a scale consistent with the underlying adjustment pattern and financing need. Before approval of the PRGF-supported program, the authorities also will have to reach understandings with the World Bank and the African Development Bank (AfDB) on a plan and modalities for arrears clearance with these institutions.

10. Immediately after clearing its arrears with the Fund, the DRC would convert to its new quota under the Eleventh General Review of Quotas. The required subscription payment in foreign currency (SDR 61 million) could be immediately financed through a reserve tranche drawing.

11. The DRC's renewed access to Fund resources, especially under such conditions and on a large scale, presupposes the establishment of a solid track record of policy performance under the SMP. It is hoped that the SMP will encourage a rapid resumption of donor support both in the form of financial aid on highly concessional terms and of technical assistance (see para. 26 below).

\section{RECENT ECONOMIC DEVELOPMENTS ${ }^{8}$}

\section{As indicated in the memorandum on economic and financial policies (MEFP)} (Appendix I, Attachment I), the economic and social situation has deteriorated significantly during the war that broke out on August 2, 1998, which has involved not only a systematic plundering of the nation's natural resources, the death of more than three million Congolese, the displacement of populations, and growing numbers of refugees, disabled persons, and orphans, but also the destruction of infrastructure, including hospitals, and schools. The mortality rate has increased, and malnutrition has become widespread. About half of the national territory is occupied. These developments have added to the

\footnotetext{
${ }^{7}$ A bilateral creditor has already agreed in principle to provide such a bridge loan.

${ }^{8}$ More detailed economic and financial information can be found in the accompanying paper on recent economic developments.
} 
effects of economic mismanagement and the prolonged rundown in the economic and social infrastructure since the early 1990s.

13. The authorities and the staff concurred that the economic situation of late 2000early 2001 was characterized by a vicious circle of hyperinflation, continued depreciation of the currency, increasing dollarization and financial disintermediation, lack of saving, falling production in both agriculture and manufacturing, deterioration of economic infrastructure, generalized impoverishment of the population, an alarming spread of epidemics such as HIV/AIDS, and the reappearance of previously eradicated diseases, like tuberculosis and leprosy. Also, the production of manioc, one of the major staple foods, has been seriously affected by a rapidly spreading plant disease. The lack of medical supplies is further aggravating the situation. The scarcity of inputs in all sectors has contributed to a continuing decline in production and the rising cost of goods and services. ${ }^{9}$ The government has also had to contend with a serious lack of the office materials and supplies that are needed to operate adequately.

14. In this context, real GDP has fallen by 5 percent per year on average over the past three years (Table 1 and Figure 1). Output in all sectors is well below 1990 levels, and per capita real GDP plummeted from US $\$ 224$ in 1990 to US\$85 (or 23 cents a day) in 2000. Consumer prices rose at an annual average rate of 107 percent in 1998,270 percent in 1999, and 554 percent in 2000; this deterioration continued through the first four months of 2001 with a cumulative rate of 68 percent. The gap between the official and parallel exchange rates widened from 44 percent at end-1998 to 545 percent in mid-May 2001. Gross international reserves at end- 2000 stood at the equivalent of only 2.2 weeks of imports of goods and nonfactor services. External debt rose to 280 percent of GDP (or almost US $\$ 13$ billion) at end-2000, with arrears accounting for about 75 percent of the total. Multiple exchange rates and controls on prices have resulted in significant distortions in relative prices and shortages of basic items, as well as petroleum products. The regulatory framework has become heavy, lacks transparency, and has been applied in an arbitrary fashion, resulting in a climate of suspicion and economic insecurity that has discouraged investment. Poor maintenance has led to the rundown of infrastructure and the capital stock.

\section{The staff agreed with the authorities that the primary source of the} hyperinflation was the unbridled monetization of an uncontrolled budgetary deficit. The deficit stems from the collapse of the expenditure control system and of fiscal revenue, which as a share of GDP, has fallen to one of the smallest in Africa. The lack of transparency and problems of governance have also contributed to this situation. Moreover, most of the

\footnotetext{
${ }^{9}$ Data are incomplete owing to the war situation and because the bases for calculating some data in the area of public finance and the real sector are outdated. A Fund technical assistance mission visited Kinshasa in June 2001 to address the problems in the statistical area, particularly regarding public finances and the real sector.
} 
agencies involved in the budgetary process (for both revenues and expenditure) are badly underequipped.

16. In 2000 , the budget deficit (on a commitment basis) is estimated to have been equivalent to about 120 percent of government revenues. With the decline in economic activity and the shift of transactions to the nonofficial economy, the tax base has been shrinking. ${ }^{10}$ This shrinkage has been exacerbated by numerous tax exemptions, widespread fraud in the tax administration, and the diversion of revenues from the budget, in particular those from the public mining companies (GECAMINES and MIBA), and the petroleum products sector. As a result, budgetary revenues collapsed, amounting to less than 5 percent of GDP in 2000 (Table 2). Recorded budgetary expenditures (excluding interest due) are estimated to have been almost twice as large as revenues-equivalent to almost 9 percent of GDP. Security-related payments, including military wages, have been given priority while other payments have been cut back. Investment outlays have become negligible, and no external debt service payments have been made. Control over public expenditure is very weak with significant extrabudgetary spending, largely for sovereign and security-related purposes (which amount to 70 percent of total revenue) and partly funded by diverted tax revenues. "The overall deficit has been almost entirely financed by monetary expansion and through accumulation of domestic and external arrears.

\section{During the first four months of 2001, fiscal revenue collection remained weak} while the pace of spending remained fast. The authorities granted sizeable salary increases to the military, police, and civil servants in late 2000 , partially to offset the sharp decline in real wages during recent years (Figure 2D). On the revenue side, the diversion of significant revenues from the budget continued.

${ }^{10}$ Key revenue issues are described in Box 1.

${ }^{11}$ Key issues in public expenditure management are discussed in Box 1. 


\section{Box 1. Key Issues in the Fiscal Area}

Revenue collections recorded in the central budget were equivalent to only 3.6 percent of GDP in 2000, and amounted to less than 5 percent of GDP including off-budget revenue. With the decline in economic activity and the shift of transactions to the nonofficial economy, the tax base has been shrinking. The poor revenue performance also results from the following:

- The structures of the import tariff and tax system are complex. The multiplicity of customs tariffs and tax rates complicates the tasks of the revenue collecting agencies and provides opportunities for fraud and discretionary decisions.

- There are numerous exemptions and exceptions to the import tariff and tax codes.

- The consumption tax (contribution sur le chiffre d'affaires) has a narrow base due to numerous exemptions.

- Fraudulent operations in tax collections through commercial banks were reported to have increased significantly in 2000 .

- Revenue from duties and taxes on imports have eroded during the last two years because the official exchange rate (and not the market exchange rate) has been used to detcrmine the value of taxable imports.

- The diversion of revenue from the budget is widespread, in particular for those special levies (taxes para-fiscales) applied to imports of petroleum products.

- For the last two years, the mining industry's tax contribution (in particular of GECAMINES and MIBA) to the budget has been subject to negotiated arrangements.

- For the last fifteen years, the two main revenue collecting agencies, the Office des Douanes et Accises (OFIDA) and the Direction Générale des Contributions (DGC) have received only limited assistance to reform and modernize their organizations and procedures. They are badly under-resourced.

Against a background of war, hyperinflation, and cash shortage, established budget procedures were rendered totally ineffective in the DRC in 1999 and 2000:

- Significant outlays, inter alia, on sovereignty and security, werc implemented outside the budget execution process and not recorded by the treasury. Some of these expenditures were undertaken or financed by GECAMNES (mining), MIBA (diamonds), and the petroleum sector.

- Defense expenditure through the treasury was only recorded in aggregate, with little information on military wages and other sub items.

- More than half of total expenditure was carried out through emergency procedures without proper recording, resulting in an absence of control and a large stock of expenditure to be regularized at the end of each year.

In those circumstances, budget monitoring and even cash monitoring were performed on an ad hoc basis, and little control over expenditure was achieved. External and domestic arrears accumulated. Wages for civil servants who are in the territories outside the government's control have not been paid since 1998 (about 120,000 civil servants -25 percent of the total civil service—reportedly are in this situation). With hyperinflation, the salary in early 2001 of a lower-ranking civil servant in nominal terms was equivalent to less than US $\$ 3$ per month, and that of a secretary-general of a ministry to less than US\$30 per month. 
18. The monetary authorities pointed out that, in the circumstances, the role of the BCC was largely reduced to financing the fiscal deficit along with providing some lending to public enterprises and the private sector (at highly negative real interest rates). As a result, broad money grew by 160 percent in 1998, by 382 percent in 1999, and by 493 percent in 2000 (Table 3 and Figure 1B). For the first three months of 2001, this growth was estimated at 35 percent. The staff noted that the financial position of the $\mathrm{BCC}$ had been dangerously weakened; and that a shortage of banknotes was preventing banks from withdrawing excess reserves with the BCC. Moreover, the banking system is largely insolvent, with only one bank reportedly meeting prudential norms. ${ }^{12}$ The public's loss of confidence in the national currency and the banking system has led to extensive dollarization and financial disintermediation. Domestic saving has been discouraged by interest rates that are substantially negative in real terms.

19. The external position continues to be weak, reflecting the fiscal stance and domestic supply constraints. The authorities explained that, because of the differential between the official and the parallel market rates, foreign exchange receipts of a number of public enterprises were deposited in accounts abroad putting additional pressure on the foreign exchange market. Foreign exchange reserves are very low, and, in the absence of external financing, the overall balance of payments position has largely been financed by the continued accumulation of external debt service arrears. The parallel exchange rate depreciated sharply to about CGF 325 per U.S. dollar in mid-May 2001, compared with the official rate of CGF 50 per U.S. dollar (CGF 25 and CGF 4.5, respectively, at end-December 1999) (see Figure 1D).

20. The stock of external debt at end-2000 amounted to about US\$13 bilition (280 percent of GDP). ${ }^{13}$ Reflecting the cessation of most payments to creditors since 1992, overdue obligations accounted for more than US $\$ 9$ billion, with arrears on principal at about US $\$ 5$ billion and arrears on interest at more than US\$4 billion. Bilateral creditors are owed more than 70 percent of the outstanding debt. The six countries with the highest claims on the DRC are the United States (US\$2.7 billion), France (US\$1.4 billion), Belgium (US\$1.2 billion), Italy (US $\$ 0.9$ billion), Germany (US $\$ 0.9$ billion), and Japan (USS0.8 billion). Outstanding multilateral debt amounted to more than US\$3 billion (including arrears). Overdue obligations to the Fund were about US $\$ 0.5$ billion, to the World Bank Group US\$0.3 billion, and to the AfDB US\$0.8 billion.

${ }^{12}$ The situation of the banking system and its supervision are discussed in Box 2 .

${ }^{13}$ See the chapter on external debt in the accompanying paper on recent economic developments. 


\section{Box 2. Banking Sector Issues}

\section{Overview}

As of December 31, 2000, the balance sheet total of all commercial banks amounted to CGF 9.5 billion. Relative to GDP, credit to the private sector stood at 0.6 percent and deposits at 1.3 percent. By comparison, these ratios were 10 percent and 15 percent in Cameroon. Of the fourteen authorized banks, only eight still do any business, which is conducted in extremely difficult circumstances. They accounted for a total of CGF 4.7 billion in deposits and CGF 2.1 billion in total loans at end-2000. Six banks, three of which are state owned, are no longer in operation.

\section{Financial situation}

Activity in the banking system has been declining, and the banks' overall financial position is precarious. The auditing of their accounts is hampered by the lack of reliable accounting data and ambiguities in the classification and provisioning of loan portfolios.

As of December 31, 2000, only one bank met the capital adequacy requirements. Insufficient equity capital is largely responsible for the nonobservance of this ratio. Indeed, the minimum capital requirement (US $\$ 5$ million) is not met by any of the banks if the requirement is converted into local currency at the unified floating exchange rate that has been in existence since May 26,2001 . The liquidity of banks, which, in terms of the required ratio, is satisfactory for nearly all banks, is in fact inflated by the maintenance of sizable excess reserves with the $\mathrm{BCC}$. These reserves exist because banks cannot withdraw available amounts in their accounts in cash, as the shortage of banknotes forces the central bank to impose quotas on withdrawals at its counters. Reported profitability is positive for only five of the eight banks in operation; however, three of them report a problem loan rate of zero.

\section{Institutional aspects}

The Comite de Restructuration du Secteur Bancaire Congolais (COREBAC), created in February 1998, is responsible for managing the reorganization of the banking system. However, there is some ambiguity about the duration of this institution's mandate, which is to expire by end-2001 even though some reorganization plans will still be in progress at that time. A "special reorganization regime" instituted in April 1998 allows banks availing themselves of COREBAC's protection to benefit from certain tax exemptions. To do so, banks must obtain COREBAC's approval of their reorganization plan.

\section{Bank supervision}

The BCC's Directorate of Supervision of Financial Intermediaries oversees the financial system and is responsible for off-site and on-site supervision. The body of Congolese regulations includes a very complete series of ratios for banks, the requirements for which take into account the country-specific context by being more strict than the generally accepted capital adequacy and risk diversification standards. As loan classification and provisioning standards are still too lax, ${ }^{1}$ capital and profits are likely to be overstated and, therefore, the effectiveness of these ratios is limited.

The commercial banks submit prudential statements for off-site supervision purposes; moreover, not all the prudential ratios are being monitored. ${ }^{2}$ The lack of a uniform Plan Comptable for the banking industry results in unreliable data and inadequate data processing by the BCC staff.

No exhaustive on-site supervision has yet been undertaken by the BCC. However, audits by external firms have been organized with World Bank financing under the Banking System Rehabilitation and Reorganization Program.

${ }^{1}$ Instruction 16 allows two years for the provisioning of problem loans with no collateral and up to four years for collateralized loans.

${ }^{2}$ With the exception of three of the fourteen licensed banks. 
21. The authorities have recently taken steps to simplify and liberalize the trade regime. In particular, the number of import tariff rates was reduced to five tariff brackets and the range of rates changed from 5-30 percent to 0-30 percent. Also, the turnover tax on imports was reduced from a range of 5-30 percent to $0-13$ percent, and the number of rates cut from five to three. In 2000 , quantitative restrictions on imports (used to protect local industry) were replaced by a surtax, with three rates of 15,20 , or 30 percent. ${ }^{14}$ With respect to export taxes, the tax ( 0.75 percent) on exports of artisanal diamonds and gold was suspended in 1999. As regards its membership in regional trade arrangements, the DRC has not ratified or signed the Southern African Development Community (SADC) trade protocol, and, while it is a member of the Common Market for Eastern and Southern Africa (COMESA), it has not yet participated in that organization's program of tariff reductions.

\section{Policy Discussions and the Fund StafF-Monitored Program}

22. To address the alarming economic, financial, and social situation, the authorities have decided to put in place a critical mass of bold and front-loaded adjustment measures, aiming principally at breaking hyperinflation, stabilizing the economic situation, and laying the foundation for a restoration of growth and reconstruction. Initiation of far-

reaching and well-sequenced structural reforms, with the World Bank taking the lead, should pave the way for a significant reduction in price distortions, strengthening of the banking sector, restoration of economic security, and the opening up and liberalization of the economy.

23. The authorities intend, in line with progress in securing peace, to put in place in due time a broader strategy for post-conflict reconstruction. They see the SMP as a critical first step for restoring economic stability to help establish the conditions for a revival in economic activity and a reduction of poverty. The staff noted that a comprehensive post-conflict strategy should address the DRC's humanitarian, reconstruction, and reintegration needs (beyond the efforts already under way). The formulation of a demobilization, disarmament, and reintegration (DDR) program, with the support of the World Bank and other international donors, would be an essential element in the process of establishing social stability. The rebuilding of administrative and institutional capacity, in addition to the immediate needs under the SMP, would also be important. In light of the large needs of the DRC, a concerted international assistance effort will be important for the success of the post-conflict strategy.

24. The main quantitative objectives for 2001 are to: (i) balt the decline in real GDP that has occurred in each of the past five years; (ii) sharply reduce the annual average inflation rate to 300 percent and the end-period inflation rate to 99 percent (compared with rates of 554 percent and 511 percent, respectively, in 2000); (iii) cut the fiscal deficit from

\footnotetext{
${ }^{14}$ These apply to imports of wheat flour and tires ( 15 percent), sugar ( 20 percent), and biscuits, textiles, and electrical batteries ( 30 percent). For details, see the chapter on the exchange and trade system in the accompanying paper on recent economic developments.
} 
5.7 percent to 1.9 percent of GDP (on a commitment basis and excluding grants) and from 3.9 percent to 0.3 percent of GDP (on a cash basis); and (iv) maintain gross official reserves at a level equivalent to about two weeks of imports of goods and nonfactor services (see table below). ${ }^{15}$

Democratic Republic of the Congo: Main Quantitative Targets for 2001 Under the SMP

\begin{tabular}{lcc}
\hline & 2000 & 2001 \\
\hline Output and prices & \multicolumn{2}{c}{ (Annual percentage changes) } \\
Real GDP & -4.3 & 0.0 \\
GDP deflator & 550.0 & 260.0 \\
Consumer prices, annual average & 554.0 & 299.0 \\
Consumer prices, end period & 511.0 & 99.0 \\
& & \\
& (In percent of beginning-of-year broad money) \\
Money and credit & 493.0 & 53.0 \\
Broad money & 388.0 & 55.0 \\
Net domestic assets & 317.0 & 15.0 \\
$\quad$ Of which: Net credit to the government & \multicolumn{2}{c}{ (In percent of GDP) } \\
Central government finances & -5.7 & -1.9 \\
$\quad$ Overall balance (on an commitment basis) $1 /$ & -3.9 & -0.3 \\
Overall balance (on a cash basis) 1/ & \multicolumn{2}{c}{2.4} \\
Balance of payments & 2.2 & \\
Gross official reserves (weeks of imports) &
\end{tabular}

1/ For 2001, excluding foreign-financed investments.

25. To achieve these objectives, the macroeconomic policies envisaged in the program include a restrictive budgetary policy and a prudent monetary policy. Also, the official exchange rate has been allowed to float freely effective May 26, 2001, thereby unifying the

${ }^{15}$ There are uncertainties at this stage as to how long the peace process will take. Consequently, information on the extent of damages to infrastructure, and the possible content of a program of reconstruction, as well as a program for the demobilization and reintegration of combatants and displaced persons, is incomplete. Therefore, the staff is not in a position to develop a meaningful medium-term scenario at this juncture; however, it hopes to do so in October 2001 at the time of the first review of the SMP. 
then existing official and parallel market rates. The average rate on Monday, May 28, 2001, the first day of operation of the new system, was quoted at CGF 313.5 per U.S. dollar, representing a depreciation of the official rate of 84 percent in foreign currency terms. These policies will be accompanied by the launching of well-sequenced structural reforms in coordination with the World Bank.

26. The authorities have created an interministerial economic and financial policy monitoring committee (ECOFIN) to better coordinate government actions (see MEFP, para. 34). In addition, timely technical assistance, including in the very short-term, is envisaged to reinforce the administrative capacity to implement and monitor the program. The DRC is already receiving technical assistance from the Fund in the fiscal, monetary, banking, and statistical areas, and from the World Bank for the mining and transportation sectors. On the basis of a strategic list of projects, including the strengthening of administrative capacity, prepared in collaboration with the World Bank, a meeting of multilateral and bilateral donors is scheduled to take place in early July 2001 . The aim of the meeting will be to meet near-term needs to support the government's reform efforts and to help strengthen administrative capacity for the implementation of a possible successor PRGF-supported program, including the design of a poverty reduction strategy that could form the basis of an interim PRSP (see LOI, para. 5). Table 2 of the MEFP contains a listing of the DRC's technical assistance needs in the fiscal area.

\section{A. Fiscal Policy}

\section{The authorities concurred with the staff that a substantial tightening of} budgetary policy was key to stopping hyperinflation. The program thus includes a number of revenue-enhancing and expenditure-restraining measures in the 2001 budget consistent with a substantial reduction in domestic bank financing. The fiscal deficit, on a commitment basis and excluding foreign-financed investment, is programmed to decrease from 5.7 percent of GDP in 2000 to 1.9 percent in 2001, and on a cash basis from 3.9 percent to 0.3 percent. The government will make net payments to the banking system starting in June 2001 and during the rest of the year. A monthly treasury cash-flow plan was put in place in June 2001 to improve fiscal management and ensure that monthly expenditure does not exceed fiscal receipts. All expenditures and revenues, including those previously outside the budget, will be centralized at the treasury. The authorities also intend to take into account the recommendations of Fund technical assistance missions to strengthen budgetary procedures and revenue administration. ${ }^{16}$ The authorities will not be in a position to resume external debt service payments in 2001. In the absence of these payments, the unification of the exchange rates is expected to have a large, positive effect on the budget.

\footnotetext{
${ }^{16}$ A Fund technical assistance mission on fiscal revenue, comprising Messrs. Corfmat and Fossat, overlapped with the mission and helped to identify specific revenue enhancing measures. A Fund technical assistance mission on the strengthening of budgetary procedures is scheduled for the second half of July 2001 .
} 
28. On the revenue side, fiscal revenue is targeted to increase from 4.8 percent of GDP in 2000 to 5.2 percent in 2001. To achieve this target, the authorities have taken a number of measures, including: (i) the centralization and depositing of all receipts (tax and quasi-fiscal) in the treasury's account at the BCC; (ii) the reduction of tax exemptions; (iii) the setting of monthly revenue performance targets for the Customs Directorate (OFIDA) and the Directorate General of Taxes (DGC); (iv) the abolition of the system of offsetting - providing goods and services instead of paying duties and taxes-between enterprises and government entities (in particular, revenue from taxation of petroleum products will be fully included in the budget); (v) the elimination of any possibility of deferred tax payments (including for excises); (vi) a decision to create a large taxpayers' unit; and (vii) the assessment of import duties on the basis of the c.i.f. value of imports, calculated at the market exchange rate to be published by the $\mathrm{BCC}$ (see MEFP, para.12 and Table 1).

29. The authorities also intend to take before end-2001 the following measures: (i) define the stages leading up to the simplification of the taxation system on imports, (ii) define a plan to replace the current turnover tax with a value-added tax (VAT) in early 2003, and

(iii) conduct an evaluation to assess tax payment and revenue collection procedures.

30. To ensure transparency in the expenditure process, and to strengthen the monitoring and control of expenditure and prevent overruns, the authorities have decided to implement a number of expenditure restraining measures (see MEFP, Table 1). Total fiscal expenditure (excluding interest on external debt) is programmed to fall from 8.7 percent of GDP in 2000 to 5.3 percent of GDP in 2001. While the adjustment of expenditures under the program is relatively large, it mainly represents a cutback in extrabudgetary spending and misappropriated funds and a return to a more rational structure of spending. The major part of the adjustment will be made in subsidies, sovereign, and off-budget expenditure. Subsidies will be sharply reduced on account of the increase in petroleum prices and the unification of the exchange rate, which, inter alia, will benefit the mining and diamond companies, thereby reducing the amount of financial support from the budget. To take into account the sharp increase in prices of petroleum products and transportation, as well as the impact of the unification of the exchange rates on the cost of living, civil servant salaries, which have decreased by more than 60 percent in real terms in the last two years, were increased by 141 percent $^{17}$ in late May 2001 . These salaries, as well as those of the military and police, will not increase during the program period. In addition, military and police salaries, which in the past have increased faster than those of civil servants, are no longer being paid in U.S. dollars (or indexed to the U.S. dollar) but in Congo francs. Furthermore, military pay will be incorporated into the regular wage procedures. Overall, notwithstanding the salary increase, the wage bill, including benefits, will fall by about 25 percent in real terms in 2001 . In addition, a civil service census will be finalized by end-2001, and, pending its completion, new hiring and replacement of retiring civil servants have been frozen, except for the education and health sectors, and the rehabilitation of infrastructure. Nonsalary expenditures,

\footnotetext{
${ }^{17}$ Including an increase in benefits related to transportation.
} 
in particular sovereign expenditures and the expenditures of the provinces, will be strictly controlled. Transfers to public enterprises will be reduced significantly (see MEFP, para. 13).

31. Capital expenditures will be limited to strategic projects selected in collaboration with the World Bank; if external project or technical assistance financing is made available the overall deficit (including foreign-financed investment) will be adjusted upward (see MEFP, para. 15).

\section{B. Monetary and Exchange Rate Policies}

32. The authorities concurred with the staff that their decision to maintain the local currency (the Congo franc, CGF) necessitates the adoption of mutually consistent monetary, fiscal, and exchange rate policies aimed at breaking the vicious circle of hyperinflation and the depreciation of the CGF so as to restore price stability and confidence in the currency, and improve competitiveness.

33. In this context, a restrictive monetary policy will be implemented consistent with the objective of breaking hyperinflation and achieving the program's inflation target. For this purpose, the central bank will use base money as a monetary anchor to achieve the inflation target. Broad money is projected to grow by only 53 percent during 2001, on account of a sharp decrease in the expansion of net credit to the government by the banking system which, expressed in terms of beginning-of-year broad money, will increase by only 15 percent as compared with 317 percent in 2000 (see MEFP, para. 19 and Table 6). Under the program, net credit to the government and to public enterprises from the banking system will be subject to ceilings. All interest rates have been liberalized as of June 2001, and thus all banks are now free to set interest rates. The $\mathrm{BCC}$ will also allow its reference rate to be positive in real terms.

34. Central to the successful implementation of monetary policy will be the restoration of the independence of the BCC (see MEFP, para. 20). For this purpose, all required legislation to affirm the independence of the $\mathrm{BCC}$ will be adopted and published by end-June 2001. Also, starting in June 2001, the BCC no longer extends loans to the private sector or public enterprises, and only finances government expenditures accompanied by payment orders from the Treasury. To conduct its monetary policies, the BCC will use existing instruments, i.e., rediscount facilities, reserve requirements, and open market operations in treasury bills. So far, the BCC has issued treasury bills only on behalf of the treasury. The BCC, with Fund technical assistance, intends to review its indirect monetary policy instruments to make them more efficient and more diversified, including its open market operations in treasury bills, and to strengthen its monetary programming. Also, an independent audit of the BCC will be undertaken before end-2001.

35. The authorities intend to implement measures to strengthen the weak banking system (see MEFP, para. 21). For this purpose they will seek the assistance of the international community, including the World Bank, to complete the ongoing audits of the commercial banks. Fund technical assistance will also be provided to reinforce the 
supervision of banks. A revised banking law that incorporates the comments of Fund and World Bank staff will be published in June 2001.

36. Regarding exchange rate policy, the adoption of a floating exchange rate system on May 26, 2001, unified the then-existing multiple exchange rates. ${ }^{18}$ The new foreign exchange regulations published in February $2001^{19}$ already provide for a liberal exchange and payments system. On May 26, 2001, an interbank foreign exchange market was restored, and foreign exchange bureaus operating in the parallel market were reauthorized. The related legislation, which takes into account comments from the Fund, has been issued. The BCC publishes daily exchange rates based on the transactions carried out in these markets. The BCC will intervene in the market only to smooth exchange rate variations from day to day, but without going against fundamentals. Under the new foreign exchange regulations, there are no restrictions subject to Article XIV. Furthermore, with the restoration of the floating exchange rate system, the exchange and payments system is free of restrictions subject to Article VIII. The previous de facto multiple currency practice has disappeared with the new market-based exchange rate system. In 2002, the autborities intend to accept the obligations of Article VIII (see MEFP, para. 23). ${ }^{20}$

37. The external current account deficit is expected to decline in 2001 from its peak of 17.6 percent in 2000 to about 14 percent of GDP. Because of the anticipated low level of foreign financing, external arrears will continue to accumulate, and gross reserves are projected to remain at about two weeks of imports.

38. The authorities intend to start discussions in 2001 toward normalizing relations with the DRC's external creditors. It will not be possible for the DRC to service its external debt fully in 2001, and the authorities will contact their other multilateral creditors, and will inform bilateral creditors of their intention to seek rescheduling under the Paris Club in the context of a possible PRGF-supported program. The normalization of relations with creditors would at the same time be expected to lead to a resumption of new assistance, on concessional terms. The authorities intend to pursue a prudent external debt management policy and to conduct an exhaustive inventory of outstanding external debts and the stock of external arrears (see MEFP, para. 22).

${ }^{18}$ The authorities have benefited from technical assistance from an MAE expert, Mr. Bussers, who worked closely with the mission.

${ }^{19}$ Following the recommendations made during a Fund staff visit by Messrs. Clément (Head) and Youm (both AFR) in October 2000.

${ }^{20}$ See the chapter on the exchange and trade system in the accompanying paper on recent economic developments. 


\section{Structural and Sectoral Reforms}

39. The authorities recognize the importance of good governance and a transparent and fair legal and regulatory environment to encourage private sector activity and restore growth (see MEFP, paras. 24 and 25). To this end, they intend to take a number of measures, and in particular, to strengthen the judicial system with the assistance of the international community. Also, before end-June 2001, parliament will adopt the necessary legislation to introduce commercial courts that will have the sole right to act as arbitrators in commercial disputes. All cases of intervention outside proper channels, in particular by military courts, will be eliminated. All prices will be liberalized before end-June. Prices of public utilities and services (including electricity, water, and public transport) will be adjusted regularly through a transparent mechanism based on operating costs. The government has introduced a transparent and automatic pricing mechanism for petroleum products that will take into account movements in international oil prices, operating costs, and the exchange rate. Petroleum product prices were adjusted upward by about 300 percent on May 26, 2001 (see MEFP, para. 26). ${ }^{21}$

40. To create a more competitive environment in the diamond sector, the authorities have recently abolished the monopoly concession that had been granted in 2000; buyers are now free to set up operations in the sector. Also, the authorities intend to introduce certification requirements in line with recent UN resolutions (see MEFP, para. 27). The authorities are also preparing new investment and mining codes in consultation with the World Bank and other interested parties. With the assistance of the World Bank, the authorities intend to launch a public enterprise reform program, as well as a study to verify the arrears among public enterprises and between public enterprises and the government.

\section{Promotion of Transparency and Good Governance}

41. The authorities recognize that good governance and transparency are essential for creating a stable environment and ensuring economic security. To this end, they have decided to decisively address the problem of corruption (see MEFP, para. 30). Key corrective measures include, inter alia, the following:

- the centralization of all spending and elimination of all extrabudgetary outlays;

${ }^{21}$ Before this increase, most petroleum products were sold to the general public at market prices. It is reported that, following the increase, queuing at gasoline stations has disappeared. Gasoline is now available for transportation of goods to the capital and some prices of food items are reported to have decreased in Kinshasa. 
- the regular publication of the official gazette, the establishment of a transparent and competitive system of public procurement, and, in particular, the publication of public contracts exceeding a defined amount;

- the payment of taxes by the mining and diamond sectors (specifically, GECAMINES and MIBA) and the petroleum sector through normal collection procedures, instead of via specific accounts and schemes;

- the curtailment of ad hoc emergency procedures for expenditure, and a ban on payments made on behalf of the government without corresponding payment orders;

- the development of an action plan for dealing with corruption in customs services and the tax administration;

- the elimination of the unauthorized use of fiscal authority by individuals and nonfiscal administrations for intimidation and rent seeking at the expense of the Treasury; and

- the replacement of military courts with commercial courts in resolving commercial disputes.

\section{StafF AppraisaL}

42. The staff fully concurs with the diagnosis of the authorities on the gravity of the economic and financial situation. Indeed, the macroeconomic situation continued to deteriorate in 2000 and the first four months of 2001, with a fall in real GDP of about 4 percent in 2000, hyperinflation of 511 percent, continued widening of the difference between the official and the parallel market exchange rates, increasing dollarization (about 85 percent of transactions in goods and services), financial disintermediation, the further accumulation of external and domestic arrears, and a very low level of foreign exchange reserves. Real GDP has fallen by an average of about 5 percent per year during the last three years. Production is well below levels recorded in the early 1990s. With the steep decline in real GDP per capita, the economic insecurity, and the effects of the war, poverty is widespread.

43. The primary source of hyperinflation has been the unbridled monetization of an uncontrolled budgetary deficit. The deficit stems from the collapse of the expenditure control system and of fiscal revenues which, as a share of GDP, have fallen to one of the smallest in Africa. A lack of transparency and problems of governance, numerous tax exemptions, widespread fraud in the tax administration, and the diversion of revenues from the budget have contributed to this situation. Recorded budgetary expenditures are estimated to have been almost twice as large as recorded revenues. There has been virtually no investment spending, and no external debt service payments have been made. Control over public expenditure has collapsed, with significant extrabudgetary spending undertaken 
largely for sovereign and security-related purposes. The overall deficit has been largely financed by monetary expansion and by the accumulation of domestic and external arrears.

44. The BCC has lost control of monetary policy, and its role has been reduced mainly to financing the fiscal deficit. Its financial position has been severely weakened, and the public's loss of confidence in the national currency and the banking system has led to extensive dollarization and financial disintermediation. The external position is fragile, as illustrated by the virtual depletion of foreign exchange reserves, the heavy external debt burden, including sizeable external arrears, and the free fall of the parallel exchange rate through May 2001.

45. The authorities intend to address the difficult situation with the implementation of a program which consists of a critical mass of bold and front-loaded adjustment measures aiming principally at breaking hyperinflation, stabilizing the economic situation, liberalizing the economy and opening it to the rest of the world, and laying the foundation for reconstruction and the restoration of growth. The authorities are to be commended for taking a courageous turn in economic policies that, if fully adhered to, will represent a clear break with the past.

46. The authorities believe that the conditions are now ripe for adopting and implementing an interim program that could be monitored by the Fund staff during the period from June 2001 to March 2002. The staff concurs with this assessment, but stresses that successful implementation of the SMP will depend critically on continued progress toward peace, the timely support of the international community, including in the very short term, the strengthening of government policy coordination, as well as the effective monitoring of the program through the ECOFIN. However, implementation of the program will take place in a very difficult environment. In particular, the security situation, while improving, remains fragile and political tensions have not yet subsided. Hence, the risks to the program are substantial.

47. The staff finds the following quantitative objectives of the program for 2001 ambitious but realistic and appropriate: (i) the revival of economic growth; (ii) an average annual inflation rate of 300 percent and an end-December rate of 99 percent; (iii) an overall fiscal deficit on a commitment basis and excluding grants, of 1.9 percent of GDP, and on a cash basis of 0.3 percent of GDP; (iv) an external current account deficit of 14.0 percent of GDP; and (v) a minimum level of gross international reserves equivalent to 2.4 weeks of imports of goods and nonfactor services.

48. The staff agrees with the authorities that achievement of the major targets call for a strong fiscal adjustment effort, a restrictive monetary policy, and a well-sequenced implementation of structural and sectoral reforms, together with the timely strengthening of administrative capacity with the help of the international community. The staff commends the authorities for their decision to implement a floating exchange rate regime on May 26, 2001, supported by the implementation of a coherent set of macroeconomic policies. The new regime, which unified existing multiple rates, will 
significantly enhance the competitiveness of the economy and improve resource allocation. The staff encourages the authorities to further liberalize the trade regime, including the simplification of the tariff structure and the elimination of tariff exemptions.

49. The staff concurs with the authorities that a key element of the program is to rein in government finances to substantially reduce the fiscal deficit, with the primary objective of breaking hyperinflation. In this regard, the staff welcomes the implementation of a monthly treasury cash flow plan as of June 1,2001, and the decision that all taxes and expenditures will be centralized at the treasury, implying the elimination of all off-budget receipts and expenditure. The strengthening of the control and monitoring of all expenditure, including sovereign and security-related expenditures, will be key to the success of the program. Therefore, the authorities are urged to rigorously implement the monthly treasury cash flow plan, which, in the second half of the year, should result in net repayments to the banking system. The authorities are encouraged to make full use of the recommendations of Fund technical assistance in the revenue and expenditure areas, as well as to improve the quality and coverage of statistics. The staff notes that the unification of multiple exchange rates should have a net positive impact on the budget. However, given the still limited amount of foreign aid expected, it is unlikely that the government will be able to fully service its external debt in 2001.

50. On the expenditure side, the staff is of the view that the increase in civil service wages that was decided at end-May 2001 is necessary to alleviate the social impact of the price adjustment measures, particularly the related steep increase in transportation costs. It will be important for the authorities to ensure that no further wage increase is allowed before end-2001, so as not to endanger the objective of breaking hyperinflation. Since hyperinflation is one of the most pernicious taxes on the population, particularly on wage earners and the poor, its elimination will alleviate considerably the hardship of the majority of the population. In addition, the staff welcomes the authorities' intention to finalize a survey of the civil service by end-2001.

51. As price stability should be the main goal of monetary policy, the BCC's advances to the government will need to be strictly limited in conformity with the forthcoming new statutes of the $\mathrm{BCC}$ and the monetary program. To regain its credibility, the BCC should have decision-making autonomy with respect to its monetary policy and the use of its instruments. The staff welcomes in this regard the new statutes of the $\mathrm{BCC}$ that the authorities intend to publish in June 2001. It also welcomes the intention of the authorities to have the $\mathrm{BCC}$ accounts audited by an internationally recognized firm before end-2001.

52. The authorities are encouraged to strengthen, with the help of technical assistance from the Fund, the supervision of the banking system. In this context, the publication of a new banking law, scheduled before end-June 2001, is welcome. The staff encourages the authorities to pursue the audits of all commercial banks in a timely manner with the help of the international community, and in particular the World Bank. 
53. On the external side, the new foreign exchange regulations in February 2001 liberalized transactions and payments. The new exchange rate system has eliminated the multiple currency practices arising from the segmentation of the exchange market that are subject to Article VIII, Sections 2(a) and 3. As a result, the DRC now maintains an exchange and payments system with no restrictions on the making of payments and transfers for current international transactions. The staff welcomes the authorities' intention to accept the obligations of Article VIII in 2002.

54. On the structural side, economic recovery will require not only a consistent macroeconomic framework, but also a clear and transparent legal and regulatory environment, as well as economic security and good governance. The staff welcomes the intention of the authorities to stop arbitrary arrests and to empower commercial courts with the sole authority to settle disputes involving economic and commercial matters. The staff commends the authorities' intention to launch an action plan aiming at the elimination of corruption in certain government services.

\section{The staff welcomes the authorities' decision to reaffirm the liberalization of} prices of goods and services. The authorities will need to review regularly the prices of electricity, water, and transportation. They are to be commended for implementing a transparent and automatic mechanism for setting the prices of petroleum products on May 26, 2001, and for making the difficult decision to increase these prices to market levels. This measure should in due course help to avoid disruptive shortages of petroleum products. The staff also welcomes the decision of the authorities to liberalize the diamond sector and to introduce the certification of diamonds to establish their origin. The staff commends the authorities for preparing mining and investment codes in coordination with the World Bank.

56. It will be important for the authorities to launch, with the help of the World Bank, the reform of the public sector and a study aimed at verifying the amount of domestic cross arrears in the public sector.

57. Overall, the staff considers that the SMP represents a credible effort by the authorities to address head-on the difficult economic and social situation in the DRC. It is of the view that this courageous and bold approach by the authorities deserves the full and immediate support of the international community not only in the form of technical assistance to buttress the administrative capacity, but also in the form of highly concessional and quick-disbursing aid, preferably grants, to finance the list of strategic projects selected with the help of the World Bank. Realization of these projects is crucial not only to alleviate a number of supply bottlenecks, particularly in the transportation sector, but also to reduce the hardship inflicted on the population during the adjustment process.

58. The staff believes that the SMP, if implemented forcefully, will create the basis for a normalization of relations with the Fund and other international creditors. It notes the authorities' wish that the establishment of a track record under the SMP would help lay the foundation for a successor program that could be supported by a PRGF arrangement, so as to have the country benefit from debt relief, in particular under the enhanced HIPC 
Initiative. In order to establish the basis for a successor PRGF-supported program, there is a need to develop a poverty reduction strategy, to reinforce good governance and administrative, institutional, and policy implementation capacity, and to garner the support of the international community through a concerted effort.

59. The staff welcomes the intention of the authorities to make public the staff report, as well as the documents related to the SMP. It is recommended that the next Article IV consultation with the DRC be held on the standard 12-month cycle. 
Table 1. Democratic Republic of the Congo: Selected Economic and Financial Indicators, 1996-2001

\begin{tabular}{|c|c|c|c|c|c|c|}
\hline & 1996 & 1997 & 1998 & $\begin{array}{l}1999 \\
\text { Est. }\end{array}$ & $\begin{array}{r}2000 \\
\text { Est. }\end{array}$ & $\begin{array}{l}2001 \\
\text { Prog. }\end{array}$ \\
\hline & \multicolumn{6}{|c|}{ (Annual percentage clanges, unless otherwisc indicated) } \\
\hline Output and prices & & & & & & \\
\hline Real GDP & -1.0 & -5.6 & -1.6 & .10 .4 & -4.3 & 0.0 \\
\hline GDP deflator & 650 & 57 & 136 & 462 & 550 & 260 \\
\hline Consumer prices, annual average & 617 & 199 & 107 & 270 & 554 & 299 \\
\hline Consumer prices, end of period & 693 & 14 & 135 & 484 & 511 & 99 \\
\hline \multicolumn{7}{|l|}{ Extomal sector } \\
\hline Exports, f.o.b. (in U.S dollar tems) & 0.0 & -28.0 & -0.7 & -20.9 & -88.5 & 1.2 \\
\hline Import, fo.b-(in U.S. dollar terms) & 3.8 & -19.3 & 8.6 & -9.9 & -6.6 & -16.2 \\
\hline Export volume & 1.0 & .15 .1 & 7.0 & -22.1 & .13 .4 & 11.9 \\
\hline Import volume & 6.7 & -13.1 & 55.7 & -10.4 & -4.3 & -17.7 \\
\hline Tetros of trade & 1.7 & -8.7 & 33.1 & 1.0 & -3.7 & -11.1 \\
\hline Nominal effective cxchange rate $l i$ & -85.3 & -67.3 & .13 .2 & -35.4 & -83.1 & $\ldots$ \\
\hline Real effective exchange rate $1 /$ & -0.5 & 22.7 & 3.9 & 168.8 & -22.3 & $\ldots$ \\
\hline Nominal effective exchange rate $2 /$ & -86.3 & -64.8 & $-2 ! .7$ & -76.9 & -85.6 & $\ldots$ \\
\hline \multirow[t]{2}{*}{ Real effective cxehange rate $2 /$} & -8.5 & 34.1 & -10.1 & .26 .7 & -0.9 & $\cdots$ \\
\hline & \multicolumn{5}{|c|}{$\begin{array}{l}\text { (Changes in percent of beginnitg-of-year broad moncy, } \\
\text { umless otherwise indicated) }\end{array}$} & \\
\hline Money and credit & & & & & & \\
\hline Broad meney & 523 & $\pi$ & 160 & 382 & 493 & 53 \\
\hline Net domestic assets & 264 & 157 & 121 & 423 & 388 & 55 \\
\hline Net aredit to the gowcroment & 13] & 154 & 104 & 392 & 317 & 15 \\
\hline Credit to the private sector & 108 & 3 & 13 & 26 & 61 & 39 \\
\hline Credit to the parastatals & 24 & 0 & 4 & 4 & 10 & 2 \\
\hline \multirow[t]{2}{*}{ Central bank interest rate (level in percent) } & 238.0 & 13.0 & 22.0 & 120.0 & 120.0 & 140.03 \\
\hline & \multicolumn{5}{|c|}{ (In percent of GDP) } & \\
\hline \multicolumn{7}{|l|}{ Central government finances } \\
\hline Reventue (excluding grants) & 5.4 & 9.4 & 5,9 & 4.6 & 4.8 & 5.2 \\
\hline Grants (including relief aid) & 0,0 & 0.0 & 0.0 & 0.0 & 0.0 & 0.0 \\
\hline Expenditure 4 & 9.6 & 20.2 & 12.1 & 9.8 & 10.5 & 7.1 \\
\hline Primary balance (cash basis) 5/ & -1.2 & -6.1 & -2.4 & -3.0 & -3.7 & -0.2 \\
\hline Owerall balance (commitment basis) & $-4,2$ & -10.8 & -6.2 & -5.2 & -5.7 & -1.9 \\
\hline Overall balance (cash basis) & 4.6 & -6.3 & -2.7 & -3.5 & -3.9 & -0.3 \\
\hline \multicolumn{7}{|l|}{ Investment and savilug } \\
\hline Gross national savings & 20.0 & 12.0 & 11.5 & 10.0 & 6.0 & 8.0 \\
\hline Goverament & -0.7 & .5 .3 & -2.6 & -2.4 & -5.3 & -1.6 \\
\hline Nongovemment & 20.7 & 17.3 & 14,1 & 12.4 & 11,3 & 9.6 \\
\hline Investment & 27.1 & 27,9 & 20.7 & 24.1 & 23.6 & 22.0 \\
\hline Government & 0.5 & 0.9 & 0.1 & 1.1 & 0.3 & 0.3 \\
\hline \multirow[t]{2}{*}{ Nongoverniment } & 26.6 & 27.0 & 20.6 & 23.0 & 23.3 & 21.7 \\
\hline & \multicolumn{5}{|c|}{ (In millions of U.S. dollars, unless otherwisc indicated) } & \\
\hline \multicolumn{7}{|l|}{ Balance of payments } \\
\hline Experts of goods and nonfactor services & 1.738 & 1,255 & 1,240 & 1,003 & 829 & 839 \\
\hline Impetts of goods and nonfactor services & 1,756 & 1,332 & 1,369 & 1,172 & 1,224 & 1.104 \\
\hline External current account (in percent of GDP) & -7.1 & .15 .9 & -9.2 & -14.1 & -17.6 & -14.0 \\
\hline Gross official reserves (end of period) & 72 & 47 & 60 & 66 & 52 & 52 \\
\hline Grass official reserves (weeks of imports) & 2.1 & 1.8 & 2.3 & 29 & 2.2 & 2.4 \\
\hline \multicolumn{7}{|l|}{ External public deb: } \\
\hline Total, including IMF $6 /$ & 13,086 & 12,634 & 13,506 & 13,238 & 12,862 & 12,957 \\
\hline Of which: arrears & 7,477 & 7,769 & 8,710 & 9,222 & 9,597 & 10,027 \\
\hline Nel present yalue of debt (NPV) $7 /$ & & & & & $i 1,888$ & $\ldots$ \\
\hline Scheduled debu service, excluding arrears & 594 & 575 & 611 & 523 & 438 & 431 \\
\hline In percent of exports of goods and services & 34 & 46 & 49 & 52 & $\$ 3$ & 5] \\
\hline In percent of govenment revemue & 189 & 157 & 248 & 236 & 201 & 189 \\
\hline \multicolumn{7}{|l|}{ Exchange rate } \\
\hline Units of local currency per U.S. dollar 8 / & 1.1 & 1.3 & 2.4 & 4.5 & 50.0 & $50.0 \mathrm{3} /$ \\
\hline Parallel tharket rate per U.S. dollar 8 & 1.1 & 1.3 & 3.6 & 25.0 & 141,0 & $300.0 \mathrm{~J}$ \\
\hline
\end{tabular}

Sources: Congolese authorities; and staff estimatcs and projections.

If Amsual averages based on official rates. Minus sign indicates depreciation.

2f Annual awerages based on parallel merket rates. Minus sign indicates depreciation.

3/ Mid-May; on May 26, a floating cxchange rate system was introduced.

$4 /$ Including intercst due on cxtcrnal debt.

5/ Revenuc and grants minus noninterest expenditure.

6/ End of period. Outstanding debt stock includes all artears.

$7 /$ The net present value of cxternal public debt is 92 percent of the noninal value, reflecting the significant stock of arrears.

\$/ End of period. 
Table 2: Democratic Republic of the Congo: Central Government Financial Operations, 1996-200] (In millions of CGF, unless otherwise indicated)

\begin{tabular}{|c|c|c|c|c|c|c|}
\hline & 1996 & 1997 & \pm 998 & $1999^{\prime}$ & $\begin{array}{c}2000 \\
\text { Est. }\end{array}$ & $\begin{array}{l}200 \mathrm{I} \\
\text { Prog. }\end{array}$ \\
\hline Total tevenue and grants & 157 & 404 & 591 & 2,329 & 15,091 & 58,915 \\
\hline Total revenue & 157 & 404 & 591 & 2,329 & 15,091 & 58,915 \\
\hline Customs and excise (OFIDA) & $\ldots$ & ... & 269 & 717 & 4,948 & 25,000 \\
\hline Direct and indirect taxes (DGC) & $\ldots$ & $\ldots$ & 247 & 793 & 3,917 & 10,424 \\
\hline Petrolcum (royalties and taxes) & $\ldots$ & $\ldots$ & 22 & 102 & 1,091 & 11,989 \\
\hline Other $1 /$ & $\ldots$ & $\ldots$ & 53 & 717 & 5,135 & 11,502 \\
\hline Total grants $2 /$ & 0 & 0 & 0 & 0 & 0 & 0 \\
\hline Total expenditure & 279 & 869 & 1,206 & 4,934 & 32,996 & 80,393 \\
\hline Current cxpenditure & 266 & 830 & 1,197 & 4,325 & 27,420 & 66,049 \\
\hline Wages & $\ldots$ & 309 & 528 & 2,079 & 7,312 & 20,885 \\
\hline Interest due $3 /$ & 87 & 204 & 375 & 1,116 & 6,181 & 21,617 \\
\hline Subsidies $4 /$ & $\ldots$ & 3 & 9 & 15 & 1,869 & 4,696 \\
\hline Other current expenditure & $\ldots$ & 314 & 286 & 1,115 & 32,058 & 18,851 \\
\hline Of which: centralized payments & $\ldots$ & $\ldots$ & 26 & 76 & 1,663 & 6,248 \\
\hline Off-budget expenditure & $\ldots$ & $\ldots$ & $\ldots$ & 55 & 3,835 & 2,896 \\
\hline Capital expenditure & 13 & 39 & 9 & 554 & 1,062 & 3,227 \\
\hline Other operations & $\ldots$ & $\ldots$ & 0 & 0 & 679 & 1,941 \\
\hline Guaranlee and Contingency Fund 5/ & 0 & 0 & 0 & 0 & 0 & 6,280 \\
\hline Overall balance (commitment basis) & -122 & -465 & -615 & $-2,606$ & $-17,905$ & $-21,479$ \\
\hline Primary balance (commitment basis) & -35 & -261 & -239 & $-1,489$ & $-11,723$ & 139 \\
\hline Change in arrears $6 i$ & 77 & 192 & 348 & 820 & 5,723 & 18,245 \\
\hline Overall balance (cast basis) & -45 & -273 & -267 & $-1,785$ & $-12,181$ & $-3,234$ \\
\hline Primary baladce (cash basis) & -35 & .261 & -239 & $-1,489$ & $-11,723$ & $-2,62]$ \\
\hline Total financing & 36 & 266 & 309 & 3,017 & 11,774 & 3,234 \\
\hline Domestic financing & 36 & 266 & 309 & 3,017 & 11,774 & 3,234 \\
\hline Central bank & 36 & 266 & 309 & 3,017 & 12,061 & 234 \\
\hline Commercial banks & 0 & 0 & 0 & 0 & -287 & 3,000 \\
\hline Treasury bills (net) & 0 & 0 & 0 & 0 & 49 & 3,000 \\
\hline Other & a & 0 & 0 & 0 & -336 & 0 \\
\hline Nonbarks & 0 & 0 & 0 & 0 & 0 & 0 \\
\hline Foreign financing $2 /$ & 0 & 0 & 0 & 0 & 0 & 0 \\
\hline Amortization duc & -187 & -388 & $-1,023$ & $-4,108$ & $-23,370$ & $-86,835$ \\
\hline Arrears & 187 & 388 & 1,023 & 4,108 & 23,370 & 86,835 \\
\hline Discrepancy & -9 & -7 & 42 & 1,232 & .407 & 0 \\
\hline \multicolumn{7}{|l|}{ Memorandum items: } \\
\hline GDP (in billion of CGF) & 3 & 4 & 10 & 50 & 313 & 1,128 \\
\hline Revenue (in percent of GDP) & 5.4 & 9.4 & 5.9 & 4.6 & 4.8 & 5.2 \\
\hline Wages (in percent of GDP) & $\ldots$ & 7.2 & 5.3 & 4.1 & 2.3 & 1,9 \\
\hline Current expenditure, excl. inlerest/subsidics (in percent of GDP) & 6.2 & 14.5 & 8.1 & 6.3 & 6.2 & 3.5 \\
\hline Subsidies and ofl-budget expenditure (in percent of GDP) & $\ldots$ & $\ldots$ & $\ldots$ & $\ldots$ & 1,8 & 0.7 \\
\hline Overall cash deficit (in percent of GDP) & -1.6 & -6.3 & -2.7 & -3.5 & -3.9 & -0.3 \\
\hline Primary cash deficit (in percent of GDP) & -1.2 & -6.1 & -2.4 & -3.0 & -3.7 & -0.2 \\
\hline
\end{tabular}

Sources: Congolese authorities; and staff estjmates and projections.

1/ Tncluding off-budget revenus until May 2001.

2/ No extemal tinaneing is included in the $200 \mathrm{l}$ budget.

3/ Scheduled irterest, excluding interest on arrears.

4/ Before 1999, advances to the diamond company (MIBA) and the mining company (GECAMINES) are not identified.

$5 /$ Including about CGF 4 billion to guarantec contracts with petroleum suppliers (also included in totaI revenuc).

6/ For 1996-2000, arrears relating to interest on external debt, for 2001 domestic arrears and arrears relating to interest on external debt. 
Table 3. Democratic Republic of the Congo: Monetary Survey, 1996-2001

\begin{tabular}{|c|c|c|c|c|c|c|}
\hline & 1996 & 1997 & 1998 & 1099 & $\begin{array}{c}2000 \\
\text { Est. }\end{array}$ & $\begin{array}{l}2001 \\
\text { Pnog: }\end{array}$ \\
\hline & \multicolumn{6}{|c|}{ ( In mitlions of CGF) } \\
\hline Net foreigr azsets & $-5,83$ & -580 & $-1,417$ & $-2,176$ & $.23,045$ & $-136,990$ \\
\hline Net domeslic assets: & R! & 352 & 712 & 3,964 & 18,353 & 30,479 \\
\hline Net eredit to government & 39 & 305 & $6: 4$ & 3,631 & 15,404 & 18,608 \\
\hline Credit to the private sactor & 34 & 40 & 80 & 284 & 2,539 & 11,041 \\
\hline Credil to the parnstatals & 7 & 2 & 18 & 50 & 409 & 800 \\
\hline Eroad maney (M2) & 173 & 296 & 770 & 3,710 & 22,004 & $33,73\rfloor$ \\
\hline Narrow nomey (MI) & 110 & 223 & 638 & 3,462 & 19,373 & 29,794 \\
\hline Currency is circulation & 83 & 152 & 515 & 2,944 & 15,963 & 24,628 \\
\hline Demand deposits & 27 & 71 & 124 & 513 & 3,410 & 4,966 \\
\hline Quasi maney & 63 & 73 & 132 & 248 & 2,631 & 3,937 \\
\hline Time deposits it donnstic currency & 1 & 1 & 5 & 2 & a & 5 \\
\hline Foreign currefcy deyosits & 62 & 72 & 127 & 246 & 2,630 & 3,931 \\
\hline Import deposits & 43 & 32 & 75 & 205 & 1,554 & 1,954 \\
\hline Other itens, wet & -819 & -555 & $-1,550$ & $-2,127$ & $-28,250$ & $-142,196$ \\
\hline \multirow[t]{2}{*}{ Of which : veluation thange } & -806 & .768 & $-1,691$ & $-2,823$ & $-27,528$ & $-141,873$ \\
\hline & \multicolumn{6}{|c|}{ (Atrnual ehange in percent) } \\
\hline Nel fortugin assets & -642 & 15 & -144 & -54 & .959 & -494 \\
\hline Net domestic assets & 1,010 & 337 & 102 & 457 & 363 & 66 \\
\hline Net credit to government & 1,426 & 683 & 101 & 492 & 924 & 21 \\
\hline Credil to the private sector & 715 & 37 & 99 & 254 & 795 & 335 \\
\hline cedil to tho parastatzls & 80 & -3 & 160 & 175 & $7: 5$ & 96 \\
\hline Broad money (M2) & 523 & $\pi 1$ & 150 & 362 & 493 & 5 \\
\hline Narrow móney (M1) & 456 & 100 & 186 & 43 & 460 & 54 \\
\hline Currettcy in tireulation & 403 & 84 & 238 & 472 & 442 & 56 \\
\hline Demhathd deposits & 718 & 163. & 74 & 319 & 559 & 46 \\
\hline Qupsit money & 587 & 15 & 81 & 89 & 962 & 50 \\
\hline Time deposits in domestis currengy & 1,389 & .39 & 485 & -52 & -80 & 1,378 \\
\hline Foteigs currency depnsits & 679 & 16 & 76 & 94 & 969 & 49 \\
\hline Lraport deposits & 590 & -25 & 138 & 173 & 658 & 26 \\
\hline \multirow[t]{3}{*}{ Other iterits, net } & .594 & 32 & -179 & -37 & $.1,228$ & 40,3 \\
\hline & \multirow{2}{*}{\multicolumn{6}{|c|}{$\begin{array}{l}\text { (Annual change in percent of begiming of-pheriod } \\
\text { brogd money, unless other wise indicated) }\end{array}$}} \\
\hline & & & & & & \\
\hline Not foreign «s,ets & $-2,127$ & 60 & -283 & .99 & -562 & -518 \\
\hline Net donlextic assets & 264 & 157 & 121 & 423 & $3: 88$ & 5 \\
\hline Wet nedil to government & 131 & 154 & to 4 & 392 & $\$ 17$ & 15 \\
\hline Credit to the private sector & 106 & 3 & 13 & 26 & 61 & 39 \\
\hline Credit to the parastatals & 24 & 0 & 4 & 4 & 10 & 2 \\
\hline Broad money (MI) & 523 & 71 & 160 & $3 B 2$ & 493 & 53 \\
\hline Narrow money (Mi) & 324 & 66. & 140 & 367 & 429 & 47 \\
\hline Surrency in circulation & 298 & 40 & 122 & 316 & 351 & 40 \\
\hline Denland deposit: & 85 & 2.5 & 18 & 5. & 78 & 7 \\
\hline Quaki money & 199 & 5 & 20 & 15 & E- & 6 \\
\hline Time deposits in domestie cu rrentry & 4 & i) & 1 & 0 & 0 & 0 \\
\hline Foreign currency deposits & 194 & 6 & 19 & 15 & of & 6 \\
\hline Import deposits & 131 & -6 & 15 & 17 & 36 & 2 \\
\hline Other items, net & $-2,521$ & 152 & -336 & -75 & -704 & -518 \\
\hline \multicolumn{7}{|l|}{ Memorandusta ilens: } \\
\hline Cotrumer prices, tnnurt nwerage (percentage change) & 6.17 & 199 & 107 & 270 & 554 & 299 \\
\hline Cotsumer prices, end of periad (fercentege chathge) & 693 & 14 & 135 & 484 & $5 \$ 1$ & 99 \\
\hline GDP deflatur (permentage cher ge) & 6.50 & 57 & 136 & 462 & 550 & 269 \\
\hline Velority (GDP' brond money) & 17 & 15 & 13 & 14 & 14 & 33 \\
\hline Net foreigon assets (in millions of U.S. dollats) & -621 & $4 \times 2$ & -590 & 484 & -461 & -461 \\
\hline Montetry base (in millims of CGF) & 117 & 228 & 6.35 & 3,300 & 18,508 & 22,141 \\
\hline Money multiplier & 0.9 & 1.0 & 1.0 & 1.0 & 1.0 & 1.5 \\
\hline Currency-deposit ratio & 3 & 2 & 4 & 6 & 5 & 5 \\
\hline
\end{tabular}

Sources: Congolse authotities; and staff estimates and projections. 
Table 4. Democratic Republie of the Congo: Balance of Payments, 1996-2001

\begin{tabular}{|c|c|c|c|c|c|c|}
\hline & 1996 & 1997 & 1998 & $\begin{array}{l}1999 \\
\text { Est. }\end{array}$ & $\begin{array}{r}2000 \\
\text { Est. }\end{array}$ & $\begin{array}{l}2001 \\
\text { Pros. }\end{array}$ \\
\hline & \multicolumn{6}{|c|}{ (In millions of U.S. dollars) } \\
\hline Current account & $-4 ! I$ & -603 & -571 & -6.44 & .798 & -610 \\
\hline Excluding grants & -633 & -670 & -753 & -775 & -936 & .788 \\
\hline Trade balance on geods and services & -18 & -76 & -129 & -169 & -395 & -265 \\
\hline Exports of goods and services & 1,738 & 1,255 & 1.240 & 1,003 & 829 & 839 \\
\hline limports of goods and services & $-1,756$ & $-1,3,31$ & $-1,369$ & $-1,172$ & $-1,224$ & $-1,104$ \\
\hline of which : aid-related imports it & -221 & -69 & -183 & .131 & -110 & -169 \\
\hline Merchandise tade & 249 & 56 & -50 & $-[175$ & -275 & -98 \\
\hline Exports, f.o.b. & 1,652 & 1,189 & 1,180 & 933 & 760 & 770 \\
\hline Imports, $\Gamma_{1}, \mathrm{~b}, \mathrm{~b}_{2} i$ & $-1,403$ & $-1,132$ & $-1,230$ & $-1,108$ & $-1,055$ & -868 \\
\hline Services & -267 & -133 & -79 & 6 & -120 & -167 \\
\hline Recejpls & 86 & 66 & 60 & 70 & 69 & 69 \\
\hline Expenditure & -353 & -199 & -139 & -65 & -189 & -236 \\
\hline Income & -477 & -479 & -475 & -429 & -409 & -447 \\
\hline Recejpts & 10 & 10 & 10 & 10 & 16 & 16 \\
\hline Expenditure & -487 & -490 & -485 & .440 & -426 & -463 \\
\hline Of which: interest on public debt & -354 & -395 & -384 & -373 & -383 & -421 \\
\hline Scheduled & -191 & -202 & $-16]$ & -120 & -100 & 96 \\
\hline Altears & -163 & -193 & -223 & -253 & -283 & -326 \\
\hline Current untrequited transfers & $\$ 4$ & -48 & 33 & -45 & 6 & 102 \\
\hline Official & 221 & 67 & 182 & 131 & 138 & 177 \\
\hline Private & -137 & -114 & -149 & -177 & .131 & -76 \\
\hline Cap̣ital and financial aceount & -622 & -605 & -680 & -611 & -471 & .145 \\
\hline Capital afcount & 0 & 0 & 1 & 0 & -10 & 44 \\
\hline Financial account & -622 & -605 & -681 & -611 & -461 & -189 \\
\hline Official capital & -403 & -373 & -450 & -403 & -339 & -335 \\
\hline Distursements & 0 & 0 & 0 & 0 & 0 & 0 \\
\hline Amortization & -403 & -373 & -450 & -403 & -339 & .335 \\
\hline Private and shor-term canitai (net) & -219 & -232 & -231 & -208 & -122 & 146 \\
\hline Errors and unissions & 318 & 423 & 456 & 494 & 518 & -18 \\
\hline Overall balance & -715 & -785 & -794 & -761 & .751 & .773 \\
\hline Financing & 715 & 785 & 794 & 761 & 751 & 773 \\
\hline Of which: net change in non-Fund arrears & 710 & 732 & 794 & 750 & 704 & 740 \\
\hline Memorandum ilems: & & In pers & DP, unite & wise ind & & \\
\hline GDP at market prices (in milliors of U.S. dollars) $3 /$ & 5,771 & 3,804 & 6,218 & 4,579 & 4,540 & 4,355 \\
\hline Current account balance & -7.1 & -15.8 & -9.2 & -14.1 & -17.6 & -140 \\
\hline Current account balance, excl. grants & -11.0 & -17.6 & -12.1 & $-[6.9$ & -20.6 & -18.1 \\
\hline Trade balance on goods and services & -0.3 & -2.0 & -2.1 & -3.7 & -8.7 & $-6,1$ \\
\hline Debt service due (interest and principal) 4 / & -13.1 & -20.2 & -13.4 & -17.0 & -15.9 & -17.4 \\
\hline Net foreign assets of banking sector (millions of U.S. dollars) & -621 & .422 & -590 & -484 & -461 & -461 \\
\hline As percent of GDP & -10.8 & -11.1 & -9.5 & $-10,6$ & .10 .2 & $+10,6$ \\
\hline Gross offcialal resetves (it millions of U.S. Jullars) & 72 & 47 & 60 & 66 & 52 & 52 \\
\hline Reserves (n weeks of impots) & 2.1 & 1.8 & 2.3 & 2.9 & 2.2 & 2.4 \\
\hline
\end{tabular}

Soures: Congolese authorities; and staff estimates and projections.

1/ An average of about 90 percent of official grant assistance is assumed to be spent on imports of goods and services. Spending on the UN peacekeeping forces is not ineluded.

2/ Merchandise imports are adjusted to reflect higher estimates from customs data. Financing of these acditional imports is assumed to be financed from sales of foreign assets.

3/ Converted at the parallel market exchange rate (period average)

4/ Ineluding interest on arrears. 
Table 5. Democratic Republic of the Congo: External Public Debt, 1996-2001

(In millions of U.S. dollars)

\begin{tabular}{|c|c|c|c|c|c|c|}
\hline & 1996 & 1997 & 1998 & $\begin{array}{r}1999 \\
\text { Est. }\end{array}$ & $\begin{array}{r}2000 \\
\text { Est. }\end{array}$ & $\begin{array}{c}2001 \\
\text { Proj. }\end{array}$ \\
\hline \multicolumn{7}{|l|}{ Debt service } \\
\hline Debt service duc (including interest on arrears) & 757.0 & 767.8 & 834.0 & 776.3 & 721,4 & 756.7 \\
\hline Debt service due (excluding interest on arrears) & 594.1 & 574.9 & 611.1 & 523.4 & 438.5 & 431.0 \\
\hline Principal & 403.0 & 373.2 & 450.0 & 403.1 & 338.5 & 335.3 \\
\hline Fund & 29.6 & 20.1 & 23.7 & 11.9 & 0.0 & 0.0 \\
\hline Other & 373.4 & 353.1 & 426.3 & 391.2 & 338.5 & 335.3 \\
\hline Interest scheduled & 191.1 & 201.7 & 161.1 & 120.3 & 99.9 & 95.7 \\
\hline Fund $1 /$ & 17.8 & 15.9 & 16.3 & 14.0 & 17.1 & 16.8 \\
\hline Other & 173.3 & 185.8 & 144.8 & 106.3 & 82.8 & 78.9 \\
\hline Interest on arrears & 162.9 & 192.9 & 222.9 & 252.9 & 282.9 & 325.7 \\
\hline \multicolumn{7}{|l|}{ Debt stock $2 /$} \\
\hline Total debt, including arrears & 13,086 & 12,634 & 13,506 & 13,238 & 12,862 & 12,957 \\
\hline Of which: Fund & 510 & 506 & 541 & 544 & 506 & 522 \\
\hline Total debt, excluding arrears & 5,609 & 4,865 & 4,796 & 4,016 & 3,265 & 2,930 \\
\hline Fund & 84 & 59 & 37 & 24 & 0 & 0 \\
\hline Other & 5,525 & 4,806 & 4,759 & 3,992 & 3,265 & 2,930 \\
\hline Arrears $3 /$ & 7,477 & 7,769 & 8,710 & 9,222 & 9,597 & 10,027 \\
\hline Fund & 426 & 447 & 505 & 520 & 506 & 522 \\
\hline Other & 7,051 & 7,322 & 8,205 & 8,702 & 9,091 & 9,506 \\
\hline Principal in arrears & 3,478 & 3,851 & 4,299 & 4,699 & 5,038 & 5,373 \\
\hline Fund & 340 & 360 & 382 & 391 & 391 & 391 \\
\hline Other & 3,138 & 3,491 & 3,917 & 4,308 & 4,647 & 4,982 \\
\hline Interest in arrears & 3,980 & 4,182 & 4,342 & 4,460 & 4,560 & 4,655 \\
\hline Fund & 56 & 71 & 86 & 98 & 115 & 131 \\
\hline Other & 3,925 & 4,111 & 4,256 & 4,362 & 4,445 & 4,524 \\
\hline Change in total debt, including arrears $2 /$ & -380 & -452 & 872 & -267 & -376 & 95 \\
\hline \multicolumn{7}{|l|}{ Memorandum items: } \\
\hline External public debt (in percent of GDP) & 227 & 332 & 217 & 289 & 283 & 298 \\
\hline
\end{tabular}

Sources: Congolese authorities; and staff estimates and projections.

1/ Includcs Fund interest charges on principal in arrears.

2/ Non-Fund interest on arrears has been estimated for 1996-99 and is not included in estimates of debt stocks prior to 2000 (including valuation changes).

$3 /$ The components of the stock of arrears have been imputed from debt-service flows and may not add up to the aggregate due to valuation adjustments. 
Figure 1. Democratic Republic of the Congo: Fiscal Deficit, Money, Prices, and Exchange Rates, 1998-2001
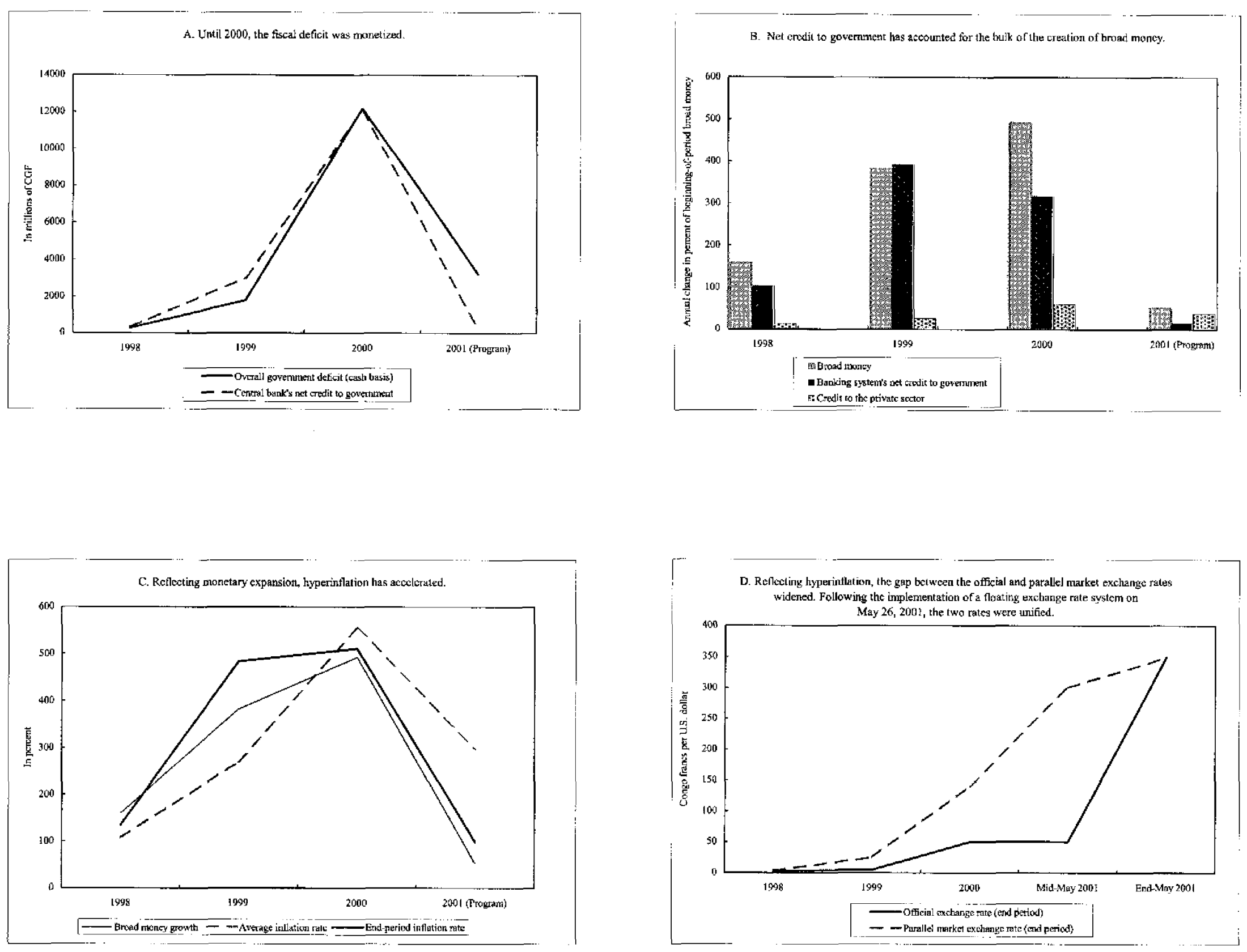
Figure 2. Democratic Republic of the Congo: Fiscal sector, 1998-2001
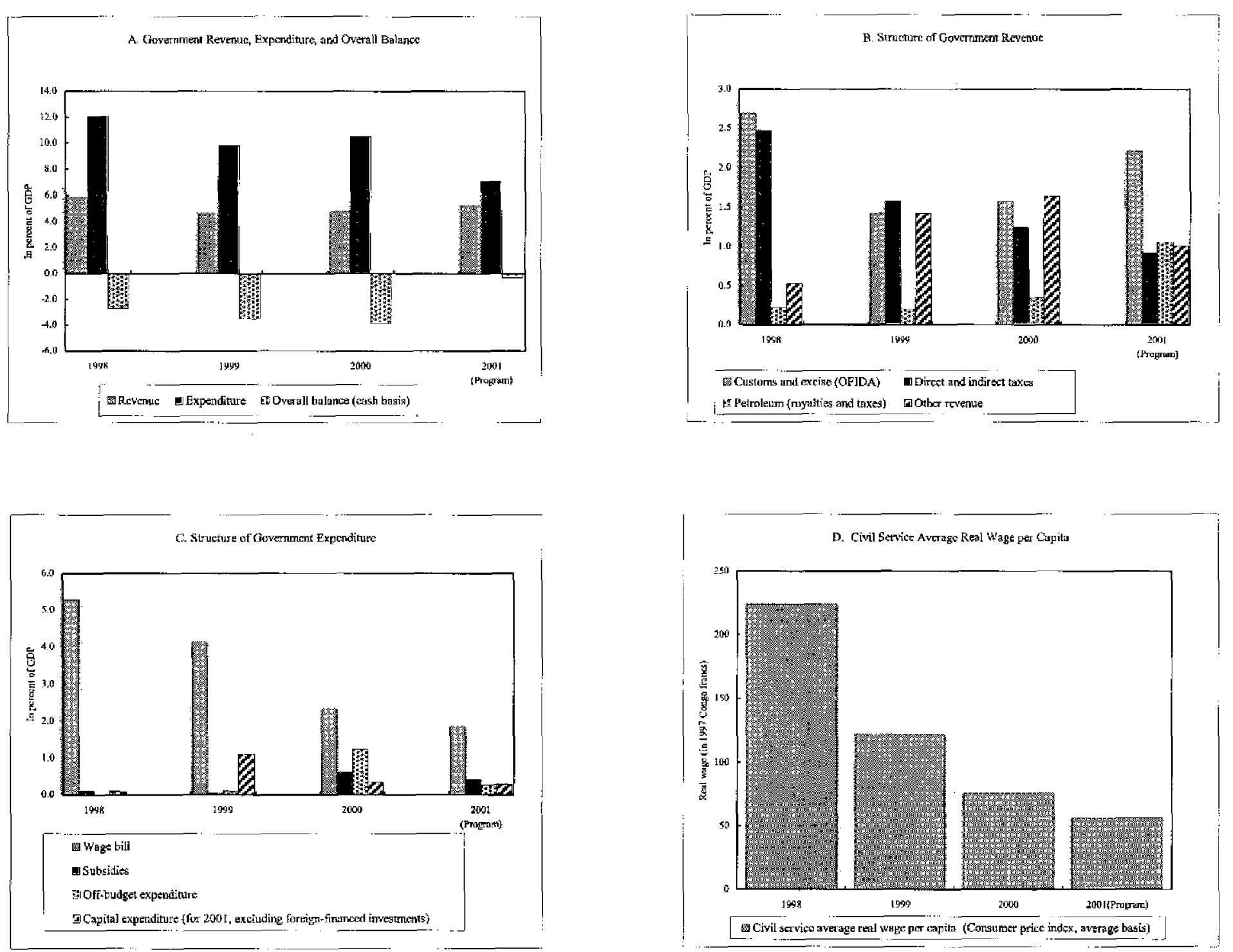
Figure 3. Democratic Republic of the Congo: External Debt

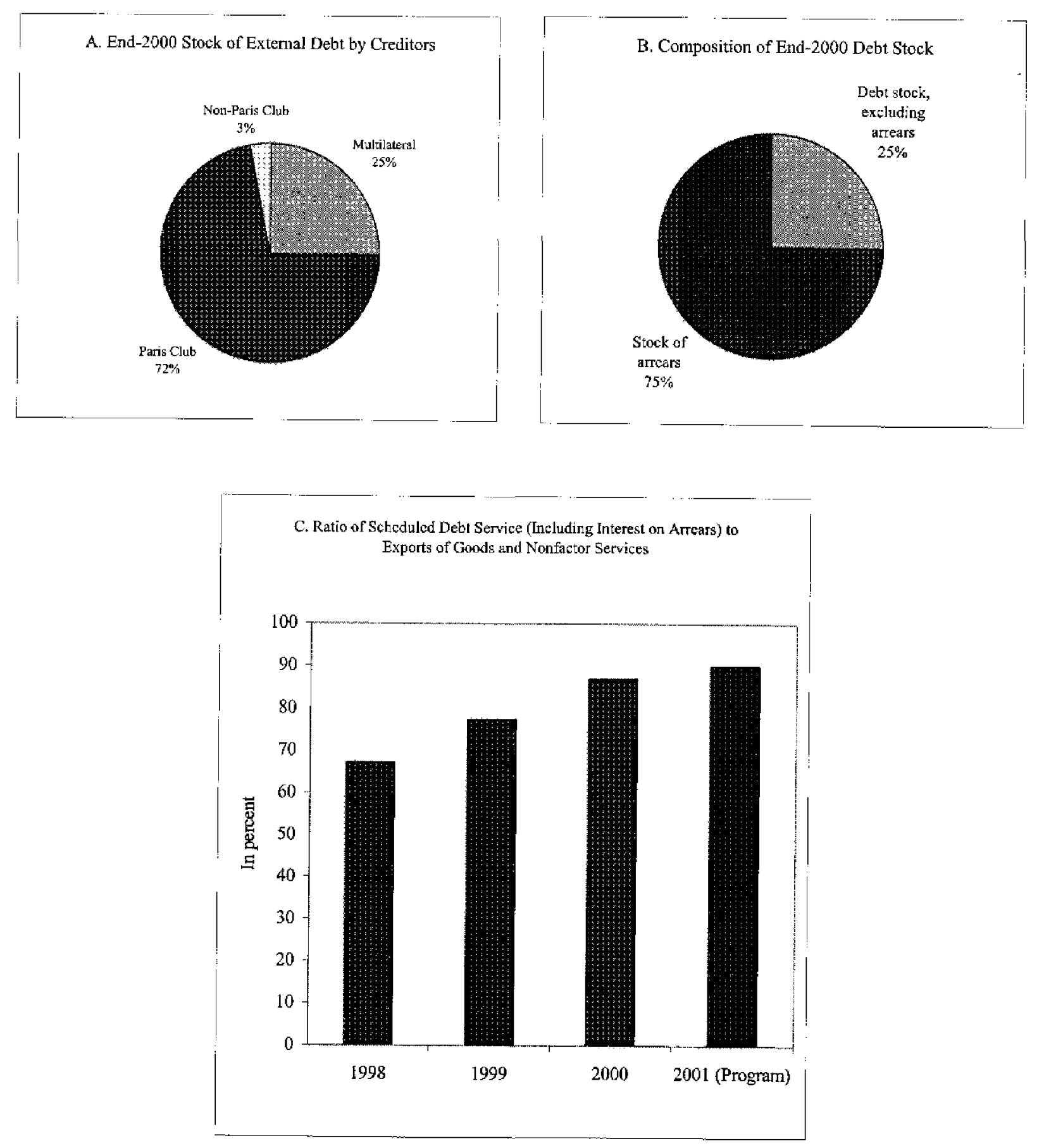


Figure 4.Democratic Republic of the Congo: Exchange Rate Indices, January 1996 - March 2001 $(1990=100$; foreign currency per franc)

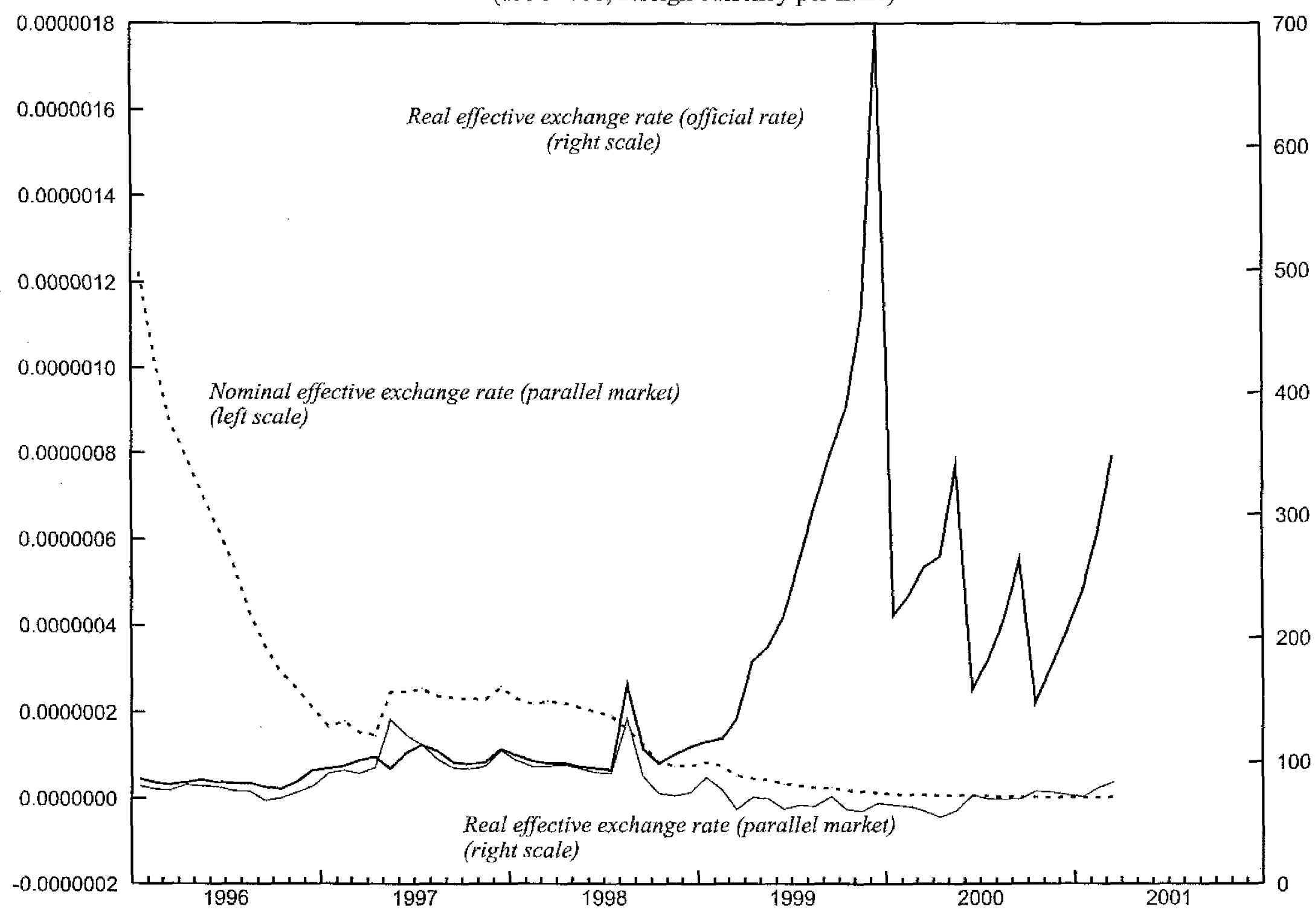

Source: IMF, Information Notice System. 
Kinshasa, June 20, 2001

Mr. Horst Köhler

Managing Director

International Monetary Fund

Washington, D.C. 20431

Dear Mr. Köhler:

1. The efforts of the new government of the Democratic Republic of the Congo (DRC) under the supreme authority of His Excellency Joseph Kabila, President of the Republic, are focused on simultaneously achieving three key objectives: (a) the restoration of peace; (b) the pursuit of a dialogue among the Congolese people, with a view to holding free and transparent elections; and (c) the liberalization of the Congolese economy, its opening to the rest of the world, and its reconstruction and revitalization. The government also intends to normalize its relations with the international financial institutions, especially the IMF and the World Bank.

2. The government is committed to rehabilitating the country's economic and financial situation and creating an environment more conducive to economic recovery. To do so, the role of the state has been redefined, and its institutions and capacities will be strengthened, so that it may become, among other things, a facilitator of, rather than a competitor with, the private sector, and so that it can focus on providing essential public services. The government intends to create a more secure and stable business environment by establishing a simplified and transparent legislative and regulatory framework, and by eliminating disruptive and arbitrary procedures. To this end, commercial courts will be established shortly. The government also intends to do more to promote good governance in the management of public affairs, including public procurement.

3. Based on a frank analysis of the present situation, the government has formulated a set of far-reaching and comprehensive economic and structural policies in the context of a consistent macroeconomic framework. The main objective of this program of economic stabilization and liberalization is to break hyperinflation. The attached memorandum on economic and financial policies, which covers the period June 2001-March 2002, sets forth the policies the government intends to firmly implement to attain its macroeconomic and structural objectives. The government hopes to receive the necessary support from Fund staff to monitor its enhanced interim program, which is described in the memorandum.

Accordingly, the government will submit to the Fund staff all information necessary to monitor implementation of the measures called for in the program.

4. The government intends to intensify its cooperation with the Fund and appreciates the in-depth Article IV consultation discussions it had with the IMF mission that visited Kinshasa from May 2-16, 2001. The government of the DRC reaffirms its desire to fully normalize its relations with the IMF and to find a solution to its arrears with the Fund. During the period June 2001-March 2002, the government will deposit a monthly amount of 
SDR 100,000 in an account of the DRC held with the Bank for International Settlements, as indicated in the memorandum. The government hopes that the implementation of this enhanced interim program and the settlement of its arrears with the Fund (possibly with external assistance in the form of a bridge loan) will lead to a three-year Fund-supported program under the Poverty Reduction and Growth Facility (PRGF). Moreover, the government has begun discussions with its external development partners to find appropriate solutions to the arrears on its debt with them, particularly the World Bank and the African Development Bank.

5. In the context of the enhanced interim program, the government, with assistance from the international community and in particular the staffs of the IMF, the World Bank, the United Nations Development Program (UNDP), and the African Development Bank, intends to initiate a dialogue with the private sector, civil society, and all other development partners with a view to developing a poverty reduction strategy. This dialogue, carried out at the national level, would provide strategic inputs for the drafting of an interim poverty reduction strategy paper (I-PRSP) and thus belp lay the foundation for a three-year program that could be supported by the IMF, the World Bank, and other external development partners. The government hopes that with these efforts the DRC will be able to benefit in due course from relief under the Initiative for Heavily Indebted Poor Countries (HIPC Initiative) and thus alleviate the heavy burden of its foreign debt.

Sincerely yours,

$/ \mathrm{s} /$

Jean-Claude Masangu Mulongo

Governor

Central Bank of the Congo /s/

Mbuyamu Matungulu Ilankir Minister of Economy, Finance, and Budget

\section{Attachments}




\title{
Democratic Republic of the Congo
}

\author{
Memorandum on Economic and Financial Policies \\ The Government's Enhanced Interim Program \\ for the Period June 2001-March 2002
}

\section{Current Economic Situation}

1. The economic situation has deteriorated significantly during the war that broke out on August 2, 1998, which involves not only a systematic plundering of the nation's natural resources, the death of more than three million Congolese, the displacement of populations, and growing numbers of refugees, disabled persons, and orphans, but also the destruction of infrastructure, including hospitals and schools. The mortality rate has increased, and malnutrition has become widespread.

2. The current economic situation is characterized by the vicious circle of hyperinflation, continued depreciation of the currency, increasing dollarization, lack of saving, financial disintermediation, falling production in both agriculture and manufacturing, generalized impoverishment of the population, an alarming spread of epidemics like HIV/AIDS, and the reappearance of previously eradicated diseases, such as tuberculosis, trypanosomiasis, leprosy, the plague, etc., as well as the spread of plant diseases that are seriously reducing the production of manioc (one of the major staple foods for the whole population). The lack of medical supplies is further aggravating the situation. The scarcity of inputs in all sectors has contributed to a continuing decline in production and rising cost of goods and services. The government also has had to contend with a serious lack of material resources. In this context, real GDP has fallen by 5 percent a year on average over the past three years. Output in all sectors is now well below the 1990 level. Per capita real GDP plummeted from US\$224 in 1990 to US\$85 (or 23 cents a day) in 2000 . Consumer prices rose at an annual average rate of 107 percent in 1998, 270 percent in 1999, and 554 percent in 2000. This deterioration continued through the first four months of 2001 , with a cumulative rate of 68 percent. The gap between the official and parallel exchange rates widened from 44 percent at end-1998 to 545 percent at mid-May 2001. Gross international reserves stood at the equivalent of only 2.2 weeks of imports of goods and nonfactor services at end-2000. External debt rose to 280 percent of GDP (amounting to almost US $\$ 13$ billion) at end-2000, with arrears of more than US $\$ 9$ billion accounting for about 75 percent of the total.

3. On the aggregate demand side, the main source of hyperinflation is the unbridled monetization of a fiscal deficit that has so far proved uncontrollable. This growing deficit is the result of the collapse of the expenditure control system and a sharp decline in the collection of revenue, which has fallen to one of the lowest levels in Africa. War-related expenditure, lack of transparency, and governance problems have exacerbated this situation. The proliferation of extrabudgetary spending, tax exemptions, quasi-fiscal operations (mainly 
involving the revenues of mining companies, such as MIBA and GECAMINES, and the oil companies), ad hoc interventions, taxpayer harassment, and corruption in a number of government services have contributed significantly to the erosion of government finances. Furthermore, with the war, security and sovereign expenses (which are partly off-budget and amount to 70 percent of total revenues), not to mention other extrabudgetary expenditures, have increased significantly. Spending on health, education, and infrastructure has remained far below the average for sub-Saharan Africa. The fiscal deficit has been financed by the Central Bank of the Congo (BCC) and through accumulation of both domestic and external arrears. The overall deficit of the government (cash basis) amounted to 45 percent of revenue in 1998 and 81 percent in 2000.

4. The drying up of external financing has compounded this difficult situation. To meet the needs of the government, the $\mathrm{BCC}$ has become a mere cashier. To cover the growing fiscal deficit and those of money-losing public enterprises, the $\mathrm{BCC}$ has printed money, and the government has accumulated arrears with its employees (wage arrears), foreign creditors, and local suppliers. The BCC has also lost all independence in the conduct of monetary policy and the control of its instruments. In addition, the BCC's financial position bas been seriously weakened. Lastly, the shortage of banknotes (whose printing costs have risen sharply owing to hyperinflation) has contributed to the disruption of the payments system and financial disintermediation. The money supply grew by 160 percent in 1998, by 382 percent in 1999 , and by 493 percent in 2000 . For the first three months of 2001 , this expansion is estimated at 35 percent.

5. The loss of confidence in the Congo franc has led to the use of foreign currencies in its place, resulting in a widespread dollarization of the economy. Financial saving in local currency has been discouraged by largely negative real interest rates.

6. The weakening of government finances, together with the fall in economic activity, has led to a deterioration of the BCC's external accounts and depletion of its international reserves. The nonrepatriation of foreign exchange earnings by a number of public enterprises has put added pressure on the foreign exchange market. Multiple exchange rates (official rate, fiscal rate, and parallel rate) and price controls (especially on petroleum products) have seriously distorted relative prices and resource allocation, and have led to shortages of essential goods and petroleum products. The regulatory framework has been increasingly burdened over the years by the proliferation of often contradictory decrees and decisions. Impromptu and often arbitrary interventions have created a climate of suspicion and insecurity that acts as a deterrent to saving, investment, and, consequently, economic growth. The virtual lack of maintenance of infrastructure and means of production has also contributed to increases in the prices of essential goods, falling production, a rural exodus, and the impoverishment of the population. This situation has been further exacerbated by the effects of the war, the displacement of populations, the influx of refugees, and the occupation of much of the national territory. 
7. Finally, poor coordination among ministries in the preparation and implementation of economic and financial policies and the absence of a consistent macroeconomic framework have added to the deterioration of the country's economic and financial situation.

\section{The Government's Enhanced Interim Program For June 2001-March 2002}

8. To address the alarming situation that the DRC is facing and correct the economic and financial disequilibria, the new government intends to put in place a coherent set of macroeconomic, structural, and sectoral policies. The main objectives of the government's enhanced interim program are to: (a) break hyperinflation; (b) liberalize the economy and open it to the rest of the world; (c) establish a more favorable environment for growth, especially for private sector activity, the true engine of growth; and (d) lay the foundation for economic reconstruction and recovery.

9. The principal quantitative targets for 2001 are the following: (a) the revival of economic growth; (b) an average annual inflation rate of 300 percent, and an endDecember 2001 rate of 99 percent; (c) an overall deficit, on a commitment basis and excluding grants, of 1.9 percent of GDP, and on a cash basis of 0.3 percent of GDP; (d) an external current account deficit of 14.0 percent of GDP; and (e) a minimum level of gross international reserves equivalent to 2.4 weeks of imports of goods and nonfactor services.

10. To reach these targets, the government intends to pursue a strict fiscal policy and a prudent monetary policy. A floating exchange rate regime was put in place on May 26, 2001, that unified the existing multiple rates, enhanced the competitiveness of the economy, and improved resource allocation. These policies will be accompanied by the sequenced implementation of major structural measures, with assistance from the World Bank in particular. The success of the program will also depend on well-targeted technical assistance to build administrative and institutional capacities. In this regard, the government is receiving technical assistance from the Fund in the fiscal and banking areas, and in macroeconomic statistics. The World Bank is providing technical assistance, in particular in the mining and transportation areas.

\section{A. Fiscal Policy}

11. A key element of the program is to rein in government finances so as to substantially reduce the fiscal deficit (cash basis), with the primary objective of breaking hyperinflation. The government intends to introduce measures designed to generate tax revenues and reduce spending. A monthly treasury cash flow plan was put in place on June 1, 2001, and all tax and off-budget revenues will be deposited in the treasury's General Account with the BCC. The government intends to take full account of the recommendations of the Fund technical assistance missions on the auditing of budgetary procedures, the modernization of fiscal and budgetary policies, and the strengthening of the financial administration (revenue collecting, budget, and treasury agencies). Given the still limited amount of expected foreign aid, it will not be possible for the government to fully service its external debt in 2001. However, the authorities will continue to pay interest on the BCC's net advances to the government. The 
interest rate on new advances will be adjusted to match the BCC's key interest rate starting in June 2001.

12. For 200I, the government has set a revenue target of CGF 58.9 billion (5.2 percent of GDP), of which CGF 25.0 billion will be customs receipts, CGF 10.4 billion direct taxes, and CGF 1.7 billion administrative and government property revenues. To this end, the measures described in Table 1 will be put in place according to the established timetable. The authorities will ensure that a sufficient supply of the necessary tax returns and assessment forms will be available. Any excess of total revenue net of refunds to the revenue-collecting agencies (régies financières) over and above the revenue programmed in the monthly Treasury cash flow plan will lower the ceiling on net banking system credit to the government.

13. The government intends to limit overall spending (excluding foreign interest payments) to CGF 59.4 billion (5.3 percent of GDP) in 2001, of which CGF 44.4 billion will be for current expenditure (excluding interest), and CGF 3.2 billion for domestically financed capital expenditure. For this purpose, the government will adopt the measures described in the attached Table 1 . In light of the large share of personnel expenses in total expenditure, the government intends to maintain strict control of the wage bill in 2001. The government has decided that, in view of the pay raises granted in recent months ( 25 percent for the military and national police and 141 percent for the civil service, including a special bonus to cover increased transportation costs owing to higher oil prices), there will be no more increases during the rest of 2001. Moreover, an in-depth study of the staffing and structure of the civil service will be conducted with the assistance of a bilateral partner and completed by end2001. While awaiting the results of this study, the government has decided to freeze hiring in all sectors and not replace retirees, except concerning the health and education sectors, and the rehabilitation of roads. Nonwage spending will be strictly limited and controlled, including sovereign expenses, the costs of missions abroad, and the expenditure of the provinces, so that maximum resources can be allocated to social and priority infrastructure spending. The government will significantly reduce subsidies to public enterprises, with a view to eliminating them when the public enterprise reform plan has been worked out with the World Bank. In anticipation of a steady return to peace, the 2002 budget will give priority to appropriations for the education and health sectors, infrastructure, and any other expenditure that will help reduce poverty.

14. The government intends to seek technical assistance from the internationa] community to help build administrative capacity for the rehabilitation of government finances, as described in Table 2.

15. In the area of capital expenditure, the government intends to carefully select projects to be retained for the remainder of 2001. Thus, the amount of domestically financed capital expenditure will be CGF 3.2 billion and will basically be allocated for spending in the following sectors: transportation, health, and rural development. The amount of capital expenditure financed with external assistance (including technical assistance for administrative and institutional capacity building) will be adjusted upward to the extent that 
foreign-financed spending is executed. The same adjustment will apply to the overall deficit. The list of foreign-financed capital expenditures was prepared jointly with World Bank staff.

\section{B. Monetary and Exchange Policy}

16. The authorities' decision to retain the local currency, the Congo franc, requires the implementation of consistent monetary, fiscal, and exchange rate policies aimed at restoring confidence in the local currency and ending the vicious circle of byperinflation and depreciation of the local currency.

17. In the area of exchange rate policy, the authorities introduced on May 26, 2001, a floating exchange rate system that unified the existing multiple exchange rates. It should be noted that the new foreign exchange regulations published on February 22, 2001, permit the unrestricted holding of foreign currencies in the DRC.

18. The government has published all legislation and regulations concerning the introduction of a floating exchange rate regime (involving the interbank market, exchange bureaus, and fund-wiring services). The government has taken due account of the Fund's comments on the drafts of this legislation. The introduction of the floating exchange rate system has also benefited from the recommendations of a Fund technical assistance mission. The $\mathrm{BCC}$ has reviewed and discussed with commercial banks their capacity to manage the exchange risk associated with the structure of their balance sheets and their foreign currency transactions. A foreign exchange interbank market was created concurrently with the introduction of the floating exchange rate system, and exchange bureaus were allowed to operate again. On the basis of information received daily by exchange bureaus and banks on the amounts and rates applied in transactions with their customers, the BCC publishes the daily exchange rate, based on transactions on each of these markets and the combined average rate of these markets. The $\mathrm{BCC}$, while respecting the international reserves target in the monetary program, will intervene to smooth exchange rate fluctuations, but without going against market fundamentals.

19. The main objective of monetary policy is price stability, and for this purpose BCC advances to the treasury will be limited in conformity with the new statutes of the BCC and the monetary program. Base money will be the monetary anchor. Money supply is projected to increase by 53 percent in 2001 , compared with 493 percent the previous year. Its growth in 2001 is below that of nominal GDP. The monetary program is described in Table 6 . In particular, net credit of the banking system to the government will increase only by CGF 3,234 million for the year 2001 as a whole; it will decrease by CGF 30 million in June 2001, by CGF 998 million between end-May and end-September 2001, and by CGF 4,376 million between end-May and end-December 2001. All interest rates have been deregulated and the $\mathrm{BCC}$ will freely set its key interest rate, which will become positive in real terms in June 2001.

20. To regain its credibility, the BCC should have decision-making autonomy with respect to its monetary policy and the use of its instruments. To ensure its independence, the 
statutes of the BCC have been revised and will be published in June 2001. The authorities have taken full account of the comments of Fund staff on the statutes. Furthermore, as of June 2001, the BCC will no longer extend credit to the private sector and to public enterprises. Moreover, the $\mathrm{BCC}$ will no longer assume responsibility for executing payment orders that have not been issued by the treasury. All $\mathrm{BCC}$ transactions in foreign exchange will be at market rates. The BCC, with Fund technical assistance, intends to review its available policy instruments and make them more efficient, as well as diversify its indirect monetary policy instruments (including for open market operations) and strengthen its monetary programming. By end-2001, the BCC will be audited by an internationally recognized firm. Finally, the authorities will seek the support of the international community to improve the BCC's Plan Comptable.

21. The authorities will adopt all necessary measures to rehabilitate the banking system. In this connection, the government will seek the assistance of the international community, including the World Bank, to conduct audits of all banks. The government intends to strengthen bank supervision with technical assistance from the Fund in particular. The new decree-law on the activities and supervision of credit institutions will be published by endJune 2001 and will take due account of the comments of Fund and World Bank staff.

22. The government intends to seek grant financing and will contract (or guarantee) only highly concessional foreign financing (except for the normal financing of suppliers' credits for imports). To facilitate relations with the international community, the government will take steps to improve external debt management and conduct an exhaustive inventory of all outstanding public external debt and the stock of arrears, with the support of the Fund and the World Bank.

23. The government undertakes not to introduce or intensify exchange restrictions, reintroduce multiple exchange rates, conclude bilateral payments agreements that are inconsistent with Article VIII of the Articles of Agreement of the Fund, or introduce or intensify import restrictions for balance of payments reasons. The government also intends to accept the obligations of Article VIII in 2002.

\section{Structural Reforms}

24. The government recognizes that economic recovery requires not only a consistent macroeconomic framework, but also a clear and transparent legal and regulatory environment. To reassure economic agents and bolster a renewed entrepreneurial confidence, the government intends, with the help of the international community, to reinforce the legal and regulatory frameworks. A bill will be adopted by parliament, by end-June 2001 at the latest, establishing commercial courts with the sole authority to settle disputes involving economic and commercial matters. All matters of an economic or commercial nature currently being dealt with by special courts, such as the military courts, will be withdrawn and transferred to regular jurisdictions, in particular the commercial courts. 
25. By end-June 2001, the government will publish a decree-law liberalizing the prices of goods and services. However, water, electricity, and public transportation rates will be set by the responsible ministries, based on transparent criteria established in consultation with professionals and user representatives. A system for regularly adjusting these rates, based on production and maintenance costs, will be agreed to by the parties. The government will seek input from certain development partners concerning the appropriate level for public utility rates.

26. The prices of petroleum products are set by the Ministry of Economy, Finance, and the Budget and the Ministry of Energy, using a formula incorporating the average border price, intermediaries' costs and margins, and the state's share (taxes and quasi-fiscal operations). The government, aware of the complexity of the current structure, has decided to simplify it and put in place an automatic, transparent system of fixing petroleum prices. In parallel with the revision of the pricing structure, the government would like to build up a security buffer stock and promote the effective liberalization of the importation and distribution of petroleum products throughout the national territory. The prices of petroleum products were raised by about 300 percent (especially for gasoline, diesel, and kerosene) on May 26, 2001, based on this new system. The prices of petroleum products will be reviewed every two weeks, and the relevant legislation has been published.

27. The government intends to continue liberalizing the diamond sector. Purchasers at trading posts may henceforth operate without restriction in the mining production zones. The authorities also intend to introduce the certification of diamonds so as to establish their origin in compliance with the UN resolution on this issue.

28. With World Bank assistance, the government has prepared a draft investment code and a draft mining code. The draft mining code is based on the conclusions of a February 2000 workshop held with all potential domestic partners and World Bank support. It was discussed in another workshop with the participation of international mining partners in May 2001. The government will take due account of the comments of World Bank and Fund staff on the draft codes before they are finalized.

29. In cooperation with the World Bank, the government will launch a reform of the public enterprise sector. A list of public enterprises to be reformed will be drawn up that will indicate the strategy to be pursued, depending on the type of enterprise in question. Also with World Bank assistance, a study will be undertaken to check cross arrears between public enterprises and between public enterprises and the state. This study will be concluded by end-March 2002 and will serve as the basis for the preparation of a timetable for the settlement of domestic arrears.

\section{Promotion Of Transparency And Good Governance}

30. The authorities recognize that good governance and transparency are essential in creating a stable environment and ensuring economic security. This is a priority for the government, and the above-mentioned measures will, in particular, ensure good governance 
in the conduct of public affairs. To that end, all expenditure and revenue were centralized and all extrabudgetary channels eliminated in early June 2001. The official gazette (Journal Officiel) will be published regularly and a competitive system of public procurement will be established, including the publication of public contracts exceeding a certain amount. Mining and diamond sector enterprises (in particular, GECAMINES and MIBA) and the oil sector will pay their taxes according to regular procedures, instead of the current system of tax compensation and off-budget operations, and they will repatriate their export earnings within the period prescribed in the exchange regulations ( 30 days). Extrabudgetary expenditure will be eliminated, and, effective June 2001, all expenditure must be executed in accordance with regular budgetary procedures. An action plan for the gradual elimination of corruption in certain government services will be implemented. Abuses of authority by individuals and nontax administrations involving intimidation, arbitrary arrests, and dishonest profit seeking at the expense of the treasury will be eliminated. Commercial courts will replace special jurisdictions for all economic and financial matters.

\section{Technical and Financial assistance And The Need For Coordination With THE INTERNATIONAL COMMUNITY}

31. The state's administrative and institutional capacities need to be strengthened, and the government intends to seek technical and financial assistance from the international community in the macroeconomic, structural, and sectoral areas. The authorities have discussed these needs with Fund and World Bank staff, and a meeting is scheduled in early July, with technical support from the World Bank, to ensure effective coordination of foreign assistance. Speedy, well-targeted assistance will be crucial to ensure the success of the program and, in particular, to finance the list of urgent and strategic projects prepared in collaboration with the World Bank. The short-term objectives are to build program implementation and monitoring capacities, begin the reconstruction of key state institutions, and put in place the necessary administrative capacity to lay the foundation for monitoring a PRGF-supported program, as well as programs of assistance of other development partners. There is also an urgent need to improve statistics in all sectors, and the authorities intend, with external assistance (particularly from the Fund), to improve the coverage and periodicity of the macroeconomic aggregates.

\section{RELATIONS WITH THE IMF AND OTHER INTERNATIONAL CREDITORS}

32. The authorities recognize the need to make progress toward clearance of arrears to the Fund during the course of the SMP (June 2001-March 2002). In light of this, they have agreed to deposit a monthly amount of SDR 100,000 in an account of the DRC held with the Bank for International Settlements. These deposits will continue to be part of the DRC's international reserves until their eventual use, and will be monitored by the Fund. Given the country's urgent needs and its limited capacity to service its external debt, it is not possible for the DRC to make larger payments. Nonetheless, the authorities are firmly committed to normalizing relations between the Democratic Republic of the Congo and the Fund. Therefore, in the context of a possible PRGF-supported program, the government intends to 
seek a bridge loan from the international community to settle the DRC's arrears with the Fund. The authorities also intend to reach an agreement with the World Bank and the African Development Bank on a plan and the modalities needed to eliminate arrears with those institutions.

33. Given the urgency of meeting the DRC's social and reconstruction needs, including, with the return to peace, its demobilization, disarmament, reintegration, and retraining needs, a reduction in the external debt burden will be an important element in the country's economic strategy. Accordingly, the authorities intend to start normalizing relations with the DRC's international creditors in 2001. It will not be possible for the DRC to service its external debt fully in 2001. The authorities will contact their other multilateral and bilateral creditors and inform them of their intention to seek rescheduling under the Paris Club, in the context of a possible PRGF-supported program. The government also intends to ask the international community, and the World Bank in particular, to help it strengthen its external debt-management capacity.

\section{Program Monitoring}

34. An interministerial economic and financial policy monitoring committee (ECOFIN) was created to better coordinate government actions and to support the introduction and monitoring of the program (Tables 1-7). ECOFIN is chaired by the Minister of Economy, Finance, and the Budget. The program will be monitored by means of quarterly quantitative indicators and structural benchmarks. A technical memorandum of understanding (attached), drafted with Fund assistance, contains a description of the indicators and the periodicity of the main data to be reported. There will be two quarterly reviews. The review to be conducted by Fund staff by end-November 2001 will be based on the end-September 2001 indicators and benchmarks, and on reaching understandings regarding the major items in the 2002 budget. The conclusion of the second review by end-March 2002 will be based on the end-December 2001 indicators and benchmarks. 


\section{Generation of revenue}

Depositing of all tax and off-budget revenue with the Central Bank of the Congo (BCC) and elimination of the system of tax offsets

Appointment of a tax and customs reform commission

Establishment of monthly revenue targets for Office des Douanes et Accises (OFIDA) and

Direction Générale des Contributions (DGC)

Elimination of all deferred payment options

Application of the market exchange rate to the c.i.f. valuation of imports

Taking of steps with financial and banking institutions participating in the collection of tax and non-tax revenue to expedite the centralization of revenue and reporting

Creation of a large enterprises' unit within the DGC and establishment of one-stop windows in the three largest OFIDA offices

Registration of all taxpayers with the DGC and OFIDA

Finalization of the draft law on the VAT and preparation of an action plan for its implementation in 2003

Assessment of payment authorization and revenue collection procedures and initial implementation of recommendations

Adoption of an action plan to reduce tax exemptions

May 2001

May 2001

May 2001

May 2001

End-May 2001

June 2001

End-2001

End-2001

End-2001

End-2001

2002 Budget Law

\section{Management and control of expenditure}

Refusal of the BCC to make disbursements that go beyond the ceiling set in the monetary program

Strict management of expenditure on a cash basis (resources actually available) as defined in the treasury cash-flow plan.

Reinstatement of budget and accounting procedures through the use of commitment vouchers for expenditure on goods and services and strict compliance with the payment authorization procedures under the supervision of the DRC treasury Directorate Coordination of commitments and payments by reinstatement of periodic commitment reports and appointment of a committee including the Minister of Finance, the SecretariesGeneral of Finance and the Budget, the Director of Budget Control, and the Director of the Treasury Launch of an audit of government and public enterptise arrears

Breakdown of the budget allocation for the armed forces

Finalization of the audit of civil service personnel and initial establishment of a database of government employees

Beginning of reinstatement of the process of expenditure control in the provinces

Preparation of a realistic 2002 budget (end-December 2001) and adoption by parliament (early 2002)

Audit of fiscal year 2001 accounts

June 2001

Jure 2001

June 2001

June 2001

August 2001

End-2001

End-2001

September 2001

2002 Budget Law

End-2002 


\section{Table 2. Democratic Republic of the Congo: Technical Assistance Requirements in the Fiscal Area}

\section{Generation of revenue}

Obtain financing for an audit of payment and collection procedures

Obtain technical assistance in support of tariff reforms and the program to modernize Office des Douanes et Accises (OFIDA) departments.

Obtain technical assistance for the preparation and introduction of a taxpayer identification number, a large taxpayers' unit, and the VAT

Obtain assistance for the establishment of a one-stop revenue collection window at the DGRAD

Obtain financial assistance for the renovation of Direction Générale des Contributions (DGC) and DGRAD buildings and offices

Obtain UN Conference on Trade and Development (UNCTAD) technical assistance to modernize the ASYCUDA customs data computer system

Obtain IDA financing to upgrade equipment, particularly computer equipment

\section{Expenditure and control of staffing}

Obtain in-depth assessment and recommendations for reinstatement of the budget and accounting functions and the expenditure control process

Seek financing for an audit of the domestic arrears of the govemment and public enterprises

Seek assistance and expert advice for the establishment of a database of government employees (civil service and non-civil service)

Seek financing to rehabilitate the work environment and procedures of the ministries

Seek financing for a review of public expenditure and an assessment of requirements in the area of infrastructure and basic services

Request medium-term assistance for integration of the expenditure control process

Launch a training program for Ministry of Finance staff on the accounting, budgetary, and supervision functions

Seek financing for partial computerization of the expenditure control process at the central level
By September 2001

By November 2001

By December 2001

By December 2001

By July 2001

By July 2001

By September 2001

Ongoing

July 2001

July 2001

August 2001-02

End-2001

End-2001

Early 2002

Early 2002 
Table 3. Democratic Republic of the Congo: Prior Actions

The government of the Democratic Republic of the Congo intends to undertake the following prior actions:

\section{Government finance}

Start execution of the 2001 budget strictly on a cash basis.

Centralize expenditure and eliminate all extrabudgetary expenditure.

Deposit all revenue in the treasury's general account with the BCC.

Finalize the list of priority strategic projects for 2001 with the World Bank.

\section{Monetary sector}

Enact and publish all legislation on the independence of the BCC, as well as the new banking law (taking due account of the comments of the IMF) by cnd-June 2001.

Liberalize all interest rates.

Ensure that the $\mathrm{BCC}$ will no longer extend direct credit to the private sector or to public enterprises. Moreover, any transaction on account of the government will require the authorization of the Minister of Economy, Finance, and the Budget.

In coordination with the Minister of Economy, Finance, and Budget, reconcile the accounts that constitute net credit to the government.

Begin strengthening the supervision of the banking system.

\section{External sector}

Introduce a floating exchange rate system and publish related legislation and regulations, taking due account of IMF comments.

\section{Structural measures}

Enhance interministerial coordination on economic and financial policies through ECOFIN.

Effectively liberalize the diamond market and publish applicable legislation.

Cease all arbitrary interference and involvement in commercial activities.

Liberalize the prices of goods by end-June 2001, with the exception of electricity, water, and public transportation, which will be adjusted periodically.

Liberalize petroleum product prices and establish an automatic and transparent mechanism for pricing petroleum products. Raise the prices of petroleum products in accordance with that mechanism. 
Table 4. The Democratic Republic of the Congo: Quarterly Quantitative Indicators March-December $20011 /$

\begin{tabular}{|c|c|c|c|c|c|}
\hline & \multicolumn{2}{|c|}{ Stock } & \multirow{2}{*}{\multicolumn{3}{|c|}{$\begin{array}{c}\text { Cumulative Changes } 2 / \\
\text { Progran }\end{array}$}} \\
\hline & & Projections & & & \\
\hline & End-March & End-May $3 /$ & End-June & End-Sep. & End-Dec. \\
\hline & \multicolumn{5}{|c|}{ (In millions of Congo franes, unless otherwise indicated) } \\
\hline \multicolumn{6}{|l|}{ Net banking system credit } \\
\hline to the government 4 / & $19,104.0$ & $23,014.0$ & -30.0 & -998.0 & $-4,376.0$ \\
\hline \multicolumn{6}{|l|}{ Net banking system credit } \\
\hline to public sector enterprises & -547.0 & 603.0 & 29.0 & 113.0 & 197.0 \\
\hline Net foreign assets of the $\mathrm{BOC}$ (floor) $4 /$ & & & & & \\
\hline (in millions of U.S. dollars) & -481.0 & $-481,0$ & -481.0 & -481.0 & -481.0 \\
\hline Cumnlative wage arrears & $\ldots$ & $\ldots$ & 0.0 & 0.0 & 0.0 \\
\hline $\begin{array}{l}\text { New nonconcessional cxtemal } \\
\text { borrowing contracted or guaranteed by } \\
\text { the goveramcnt or the BCC }\end{array}$ & $\ldots$ & $\ldots$ & 0.0 & 0.0 & 0.0 \\
\hline $\begin{array}{l}\text { Deposits of a monthly amount of SDR } 100,000 \\
\text { in an account held with the Bank for } \\
\text { International Scttlements }\end{array}$ & & & & & \\
\hline
\end{tabular}

1/ The indicators and the procedures for monitoring the indicators are defined in the technical memorandum of understanding for the 2001 enhanced interim program (Appendix I, Attachment II).

$2 /$ Cumulative changes are calculated from end-May 2001 .

3/ End-May projections take account of the gap between net credit to the government as shown in the BCC's consolidated monetary survey and records of the treasury account. It is expected that the figures will be reconciled by end-Tune 2001 .

4/ All external nonproject budget financing (estimated at zero in the budget) will lower the ceiling on net banking system credit to the government and will raise the floor on net foreign assets of the BCC by a corresponding amount. Any excess of total revenue net of refunds to the revenue collecting agencies (régies financières) over and above the revenue programmed in the monthly treasury cash-flow plan will lower the ceiling on net banking system credit to the government. 
Table 5. Democratic Republic of the Congo: Structural Performance Benchmarks

\section{By September 30, 2001, the government of the Democratic Republic of the Congo intends to do the following:}

Reinstate budget and accounting procedures through the use of commitment vouchers for expenditure on goods and services and comply strictly with payment authorization procedures under the supervision of the Directorate of the Treasury.

Execute budget on a cash basis (resources actually available) in accordance with the cash-flow plan.

Begin preparation of a public enterprise reform program with World Bank assistance.

Launch a study to identify domestic arrears between public enterprises and between public enterprises and the government.

Continue audits of commercial banks.

Finalize the investment code and the mining code prepared with World Bank assistance.

Begin the reform of the regulatory framework and the strengthening of the judicial system with assistance from the World Bank and other development partners.

Draft action plan to implement good governance.

Start work on the formulation of a poverty reduction strategy with assistance from the IMF, the AfDB, and the UNDP.

\section{By December 31, 2001, the government of the Democratic Republic of the Congo intends to do the following:}

Audit the Central Bank of the Congo.

Prepare the 2002 budget.

Complete the audit of civil service employees. 
Table 6. Democratic Republic of the Congo: Monetary Programming, 2000-01

(In millions of Congo francs)

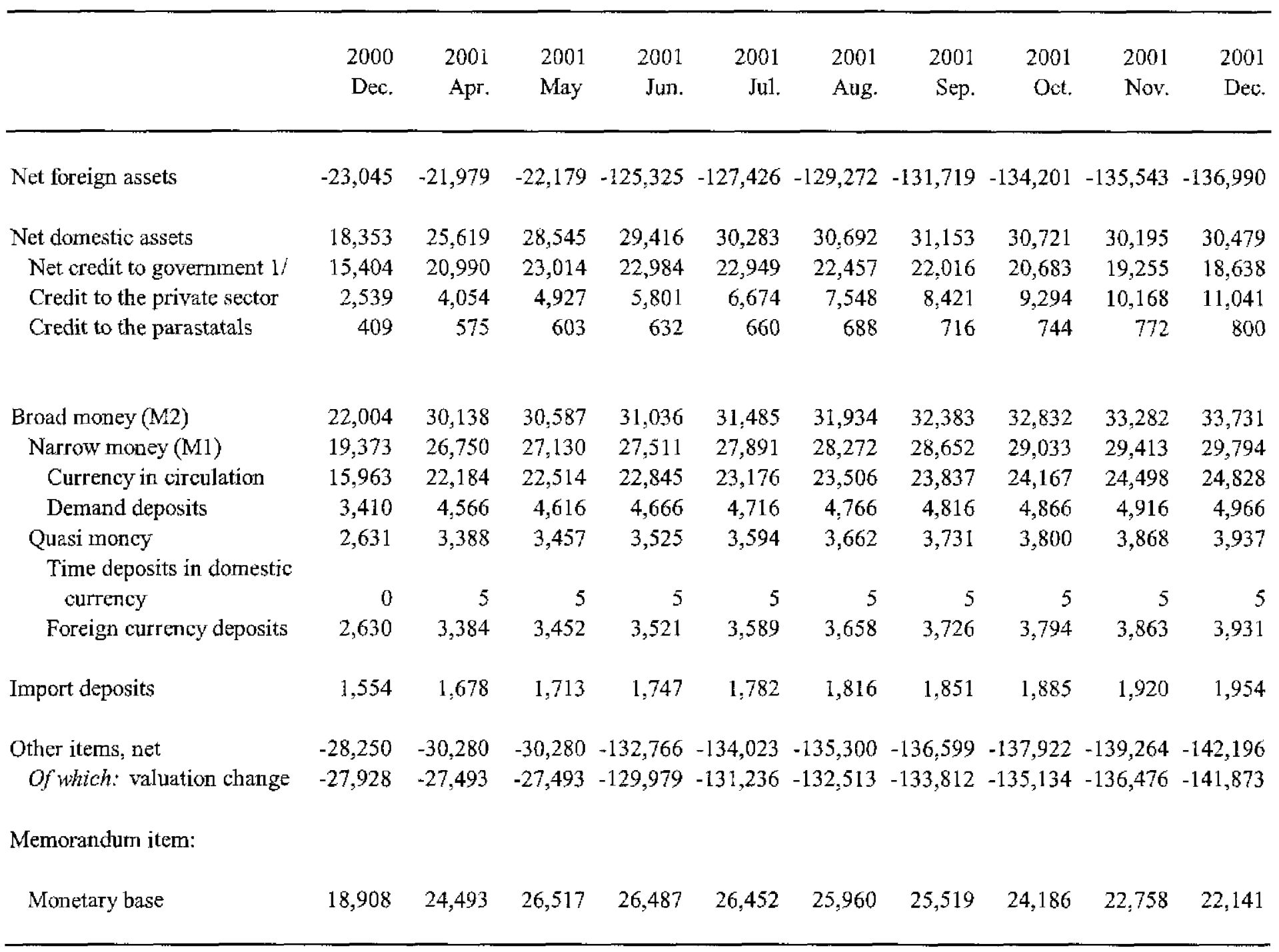

Sources: Congolese authorities; and staff estimates and projections.

1/ End-May projections take account of the gap between net credits to the government in the monetary survey and the treasury accounts. It is expected that the figures will be reconciled by end-June 2001 . 
(In millions of Congo franes)

\begin{tabular}{|c|c|c|c|c|c|c|c|c|c|c|c|c|c|}
\hline & Jan. & Feb. & Mar. & $\Lambda_{\mathrm{ppr}}$ & May & Sun. & Jul. & Aug. & Sep. & Oct. & Nov. & Dec. & $\begin{array}{l}\text { Tola } \\
2001\end{array}$ \\
\hline Total revenuc and grants I/ & 1,871 & 2,061 & 2,942 & 3,946 & 4,146 & 4,122 & 5,407 & 6,294 & 6,435 & 6,863 & 7,223 & 7,605 & 58,915 \\
\hline Total revenuc & 1,871 & 2,061 & 2,942 & 3,946 & 4,146 & 4,122 & 5,407 & 6,294 & 6,435 & 6,863 & 7.223 & 7,605 & 58,915 \\
\hline Customs and cxcise (OFIDA) & 424 & 533 & 1,176 & 1,903 & 2,069 & 2,274 & 2,365 & 2,570 & 2,526 & 2,704 & 3,008 & 3,448 & 25,000 \\
\hline Direct and indirect taxes (DGC) & 647 & 508 & 777 & 1,127 & 868 & 880 & 892 & 930 & 922 & 974 & 1,009 & 890 & 10,424 \\
\hline DGRAD & 76 & 91 & 232 & 148 & 144 & {$[44$} & 144 & 144 & 144 & 144 & 144 & 144 & 1,697 \\
\hline GECAMINES & 0 & 0 & 0 & 0 & 0 & 68 & 193 & 457 & 364 & 405 & 408 & 449 & 2,343 \\
\hline MIBA & 0 & 0 & 0 & 5 & 0 & 106 & 341 & 369 & 402 & 440 & 443 & 447 & 2,552 \\
\hline Pelroleum & 45 & 201 & 106 & 151 & 154 & 560 & 1,292 & 1,633 & 1,873 & 1,977 & 1,992 & 2,005 & 11,989 \\
\hline Othet & 3 & 113 & 205 & 182 & 182 & 91 & 181 & 192 & 204 & 219 & 220 & 222 & 2,013 \\
\hline Off-budget revenue & 675 & 616 & 446 & 431 & 729 & 0 & 0 & 0 & 0 & 0 & 0 & 0 & 2,896 \\
\hline Total grants & 0 & 0 & 0 & 0 & 0 & 0 & 0 & 0 & 0 & 0 & 0 & 0 & 0 \\
\hline Total expenditure & 2,422 & 3,753 & 5,249 & 4,981 & 6,170 & 4,092 & 5,372 & 5,802 & 5,894 & 5,030 & 4,994 & 5,628 & 59,389 \\
\hline Garrent expenditure & 1,624 & 3,043 & 4,588 & 4,236 & 4,270 & 2,660 & 3,694 & 4,035 & 4,049 & 4,072 & 4,105 & 4,667 & 45,044 \\
\hline Wagcs & 696 & 1,308 & 1,288 & {$[, 324$} & 2,033 & 2,033 & 2,033 & 2,034 & 2,034 & 2,034 & 2,034 & 2,034 & 20,885 \\
\hline Military & $\ldots$ & $\ldots$ & $\ldots$ & $\ldots$ & $\ldots$ & $\ldots$ & $\ldots$ & $\ldots$ & $\ldots$ & $\ldots$ & $\ldots$ & $\ldots$ & 7,957 \\
\hline Civilians & $\ldots$ & $\ldots$ & $\ldots$ & $\ldots$ & $\ldots$ & $\ldots$ & $\ldots$ & $\ldots$ & $\ldots$ & $\ldots$ & $\ldots$ & $\ldots$ & 12,928 \\
\hline Interest payments & 3 & 45 & 4 & 10 & 69 & 69 & 69 & 69 & 69 & 69 & 69 & 69 & 613 \\
\hline Extermal debt (payncnt) & 0 & 0 & 0 & 0 & 0 & 0 & 0 & 0 & 0 & 0 & 0 & 0 & 0 \\
\hline Domestic debt (payment) & 3 & 45 & 4 & 10 & 69 & 69 & 69) & 69 & 69 & 69 & 69 & 69 & 613 \\
\hline Other current expenditure & 471 & 1,532 & 2,488 & 2,101 & 1,368 & 478 & 1,193 & 1,532 & 1,747 & 1,770 & 1,803 & 2,367 & 18,851 \\
\hline Institutions & 25 & 345 & 701 & 700 & 500 & 89 & 89 & 89 & 89 & 89 & 89 & 89 & 2,892 \\
\hline Ministries & 299 & 534 & 995 & 831 & 650 & 100 & 250 & 400 & 448 & 448 & 448 & 842 & 6,247 \\
\hline Centralized payment (utilities) & 22 & 102 & 46 & 95 & 100 & 210 & 692 & 845 & 1,012 & 1,035 & $\mathrm{I}, 044$ & 1,045 & 6,248 \\
\hline Province & 80 & 138 & 372 & 148 & 100 & 70 & 140 & 176 & 176 & 176 & 200 & 369 & 2,144 \\
\hline Other & 45 & 412 & 375 & 328 & 18 & I0 & 22 & 22 & 22 & 22 & 22 & 22 & 1,320 \\
\hline Transfers and subsidics & 455 & 158 & 808 & 800 & 800 & 80 & 400 & 400 & 199 & 199 & 199 & 197 & 4,696 \\
\hline Pctroleum Guarantec Fund & $\ldots$ & $\ldots$ & $\ldots$ & $\ldots$ & 400 & 650 & 838 & $9 \mathrm{lt}$ & 992 & 90 & 0 & 0 & 3,880 \\
\hline Off-budget expenditure & 675 & 616 & 446 & 431 & 729 & 0 & 0 & 0 & 0 & 0 & 0 & 0 & 2,890 \\
\hline Capital expenditurc & 122 & 95 & 216 & 315 & 310 & 310 & 310 & 310 & 310 & 310 & 310 & 310 & 3,227 \\
\hline Other operations & $\ldots$ & $\ldots$ & $\ldots$ & $\ldots$ & 161 & 172 & 230 & 246 & 243 & 258 & 280 & 351 & 1,941 \\
\hline Contingency Fund & 0 & 0 & 0 & 0 & 300 & 300 & 300 & 300 & 300 & 300 & 300 & 300 & 2,400 \\
\hline Charrge in arrears $2 /$ & $\cdots$ & $\ldots$ & $\ldots$ & $\cdots$ & $\ldots$ & $\cdots$ & $\ldots$ & $\ldots$ & -100 & -500 & -800 & $-1,360$ & $-2,760$ \\
\hline Monthly balance (cash basis) & -551 & $-1,693$ & $-2,308$ & $-1,035$ & $-2,024$ & 30 & 35 & 492 & 441 & 1,333 & 1,428 & 617 & $-3,234$ \\
\hline Cumulated balance (cash basis) & -551 & $-2,244$ & $-4,551$ & $-5,586$ & $-7,610$ & $-7,580$ & $-7,545$ & $-7,053$ & $-6,612$ & $-5,279$ & $-3,851$ & $-3,234$ & \\
\hline Cumulated balance from June I & & & & & & 30 & 65 & 557 & 998 & 2,331 & 3,759 & 4,376 & \\
\hline Total bank fintancing & 551 & 1,693 & 2,306 & 1,035 & 2,024 & -30 & -35 & -492 & -441 & $-1,3,33$ & $-1,428$ & -61.7 & 3,234 \\
\hline
\end{tabular}

Sources: Congolese authorities; and staff estimates and projections.

V No cxternal financing included $\alpha b$ initio in the monthly treasury pian.

2/ Reimbursment of domestic payncnts arrears. 


\section{DEMOCRATIC REPUBLIC OF THE CONGO}

\section{Technical Memorandum of Understanding}

1. This memorandum covers the understandings on monitoring implementation of the enhanced interim program and the information to be submitted. It defines the quantitative indicators and structural benchmarks as presented in paragraph 34 of the memorandum on economic and financial policies of the Government of the Democratic Republic of the Congo (DRC), which is attached to the letter of June 20, 2001, from the Minister of Economy, Finance, and the Budget, and the Governor of the Central Bank of the Congo (BCC) to the Managing Director of the IMF.

\section{A. Monitoring Program Implementation}

2. Implementation of the program covering the period June 1, 2001-March 31, 2002, will be monitored in two ways: (a) two program reviews by Fund staff to be completed by end-November 2001 and end-March 2002, respectively; and (b) an assessment of the degree of compliance with the quantitative indicators and structural benchmarks on the scheduled dates. To that end, the government will provide all necessary data (see Section D below).

\section{B. Definition of Quantitative Indicators}

3. The quantitative indicators, shown in Table 4 of the memorandum on economic and financial policies are as follows:

(a) ceiling on net banking system credit to the government;

(b) ceiling on net banking system credit to public sector enterprises;

(c) floor on net foreign assets of the $\mathrm{BCC}$;

(d) ceiling on new nonconcessional external borrowing (including leasing) contracted or guaranteed by the government or the BCC, beginning June 1, 2001;

(e) no accumulation of wage arrears (includes all compensation);

(f) monthly deposits into an account of the DRC held with the Bank for International Settlements; and

(g) as a memorandum item, the monetary base, which serves as the monetary anchor.

4. Net banking system credit to the government includes net claims of the central bank and of deposit money banks on the government, as defined in the "Consolidated Monetary Survey" prepared by the BCC. All transitory expenditure (expenditure items in transit, recorded in subaccounts) must be excluded from government deposits with the BCC. The ceiling on net banking system credit to the government will be reduced by the amount of external nonproject financing (estimated at zero in the budget). Any excess of total revenue net of refunds to the revenue collecting agencies (régies financières) over and above the revenue programmed in the monthly treasury cash flow plan will lower the ceiling on net banking system credit to the government. 
5. Net banking system credit to public sector enterprises is equal to the difference between banking system claims on public enterprises and the latter's deposits with the banking system, as defined in the "Consolidated Monetary Survey" prepared by the BCC.

6. Net foreign assets of the $\mathrm{BCC}$ are defined as the difference between the BCC's gross foreign assets and all its external obligations, as shown in the "Consolidated Monetary Survey" prepared by the BCC. Account 02101, "Foreign exchange receivable," which, according to the explanations of BCC staff, consists essentially of advances in Congo francs (to GECAMINES and MIBA) that are to be repaid in foreign exchange, is to be excluded from net foreign assets. All external nonproject budget financing (estimated at zero in the program) will raise the floor on the BCC's net foreign assets.

7. The quantitative indicators applicable to new external borrowing are cumulative floors (effective June 1,2001) applicable to new nonconcessional borrowing (including leasing) contracted or guaranteed by the government or the $\mathrm{BCC}$, with the exception of loans granted in connection with regular imports.

8. The definition of foreign debt can be found in Decision 6230-(79/140), paragraph 9, amended August 24, 2000 (Annex I).

9. The concessional element of the borrowing will be calculated using discount rates based on the commercial interest reference rates (CIRR) established by the OECD for the currency of denomination used. A loan is deemed concessional if, on the date of the contracting, the ratio of the present value of the loan, calculated on the basis of the discount rates, to its nominal value is less than 65 percent (i.e., including a concessional element of 35 percent or more).

10. Wage arrears are defined as validated personnel expenses (according to the Directorate General of Payroll) not paid for more than 30 days. Wages include all compensation paid to employees (civil service and non-civil service, including bonuses and allowances). These arrears will be assessed cumulatively in the program.

11. The monetary base is defined as the sum of the following:

- currency in circulation (inside and outside banks);

- deposits of deposit money banks with the BCC;

- deposits of public enterprises with the BCC;

- deposits of private enterprises and individuals with the BCC; and

- deposits of other financial institutions, other than deposit money banks, with the $\mathrm{BCC}$.

Base money specifically excludes government deposits and deposits in foreign exchange with the BCC. 


\section{Structural Benchmarks}

12. The structural benchmarks are shown in Table 5 of the memorandum on economic and financial policies.

\section{Reporting}

13. The authorities will forward to the IMF African Department, as quickly as possible and preferably by e-mail or fax, the data and information needed to monitor program implementation. Following are the data or documents to be submitted.

\section{Exchange system}

(a) volume of purchases and sales of foreign exchange on the interbank market, between commercial banks and their customers, and in exchange offices;

(b) volume of purchases and sales (interventions) by the BCC on the interbank market;

(c) average CGF/USD reference exchange rate of the BCC;

(d) average CGF/USD exchange rate on the interbank market;

(e) average CGF/USD exchange rate offered by commercial banks to their customers; and

(f) average CGF/USD exchange rate used by exchange bureaus.

Note: The above information is to be submitted with a lag of one day.

\section{Financial system}

(a) consolidated monetary survey;

(b) balance sheet of the BCC;

(c) balance sheet of deposit money banks;

(d) net banking system credit to the government;

(e) net banking system credit to public sector enterprises;

(f) structure of nominal and real interest rates of deposit money banks;

(g) excess reserves (voluntary and required) of deposit money banks; and

(h) structure of BCC interest rates.

Note: The above information is to be submitted three weeks after the end of the month.

Public sector

(a) execution of the monthly treasury cash flow plan;

(b) validated wage bill by category of payee;

(c) paid wage bill by category of payee;

(d) paid employees by category;

(e) civil service pay scale (if changed); 
(f) issues and redemptions of certificates of deposit (including maturity and interest charge) and by category of creditor (commercial banks, public enterprises, etc.); and

(g) public sector domestic debt to be collected and reported as soon as data on domestic public debt become available.

Note: The above information is to be submitted three weeks after the end of the month.

\section{Real sector}

14. In this area, the authorities should report as soon as possible indicators of recent economic developments and other related data, such as the consumer price index; exports of commodities (in value and volume), including crude oil, copper, cobalt, zinc, and industrial and artisanal diamonds; imports by value and volume, if possible by principal product and petroleum products; and indicators of production of the manufacturing, mining, and services sectors, published in the BCC's monthly reports on business activity. The monthly tax base (imports) prepared by OFIDA should also be reported.

\section{External sector}

The following information on the external sector will be submitted:

(a) actual disbursements of external assistance, for project financing or otherwise, including those associated with new loans contracted, including the terms of the loans and the creditors of the latter (on a monthly basis with a lag of three weeks); and

(b) composition of external debt-service obligations, by maturity profile, as well as the stock of external arrears taking into account actual payments, with a breakdown of principal and interest and classification by creditor (to be provided quarterly by the Public Debt Management Office-OGEDEP).

\section{Miscellaneous}

15. A progress report on implementation of the structural reforms specified in Table 5 of the memorandum on economic and financial policies (Appendix I, Attachment I) will be submitted to Fund staff each month. In addition, information on the legal and regulatory environment as it affects business (new decrees, circulars, and laws), and pricing policy, as well as the official gazette, will be sent to the Fund. 


\section{Guidelines on Performance Criteria with Respect to Foreign Debt}

Excerpt from Executive Board Decision No. 6230-(79/140), as revised on August 24, 2000

9. (a) For the purpose of this guideline, the term "debt" will be understood to mean a current, i.e., not contingent, liability, created under a contractual arrangement through the provision of value in the form of assets (including currency) or services, and which requires the obligor to make one or more payments in the form of assets (including currency) or services, at some future point(s) in time; these payments will discharge the principal and/or interest liabilities incurred under the contract. Debts can take a number of forms, the primary ones being as follows:

(i) loans, i.e, advances of money to the obligor by the lender made on the basis of an undertaking that the obligor will repay the funds in the future (including deposits, bonds, debentures, commercial loans and buyers' credits) and temporary exchanges of assets that are equivalent to fully collateralized loans under which the obligor is required to repay the funds, and usually pay interest, by repurchasing the collateral from the buyer in the future (such as repurchase agreements and official swap arrangements);

(ii) suppliers' credits, i.e., contracts where the supplier permits the obligor to defer payments until some time after the date on which the goods are delivered or services are provided; and

(iii) leases, i.e, arrangements under which property is provided which the lessee has the right to use for one or more specified period(s) of time that are usually shorter than the total expected service life of the property, while the lessor retains the title to the property. For the purpose of the guideline, the debt is the present value (at the inception of the lease) of all lease payments expected to be made during the period of the agreement excluding those payments that cover the operation, repair or maintenance of the property.

(b) Under the definition of debt set out in point 9 (a) above, arrears, penalties, and judicially awarded damages arising from the failure to make payment under a contractual obligation that constitutes debt are debt. Failure to make payment on an obligation that is not considered debt under this definition (e.g., payment on delivery) will not give rise to debt. 
Democratic Republic of the Congo: Relations with the Fund (As of April 30, 2001)

I. Membership Status: Joined: 09/28/1963; Article XIV

II. General Resources Account:

Quotas

Fund Holdings of currency

III. SDR Department:

Net cumulative allocation

IV. Outstanding Purchases and Loans:

Stand-By Arrangements

Extended Arrangements

Contingency and Compensatory Financing

Facility

Structural Adjustment Facility arrangements

v. Latest Financial Arrangements:

$$
\text { Approval Expiration }
$$

$\begin{array}{ccc}\begin{array}{c}\text { Type } \\ \text { Stand-By }\end{array} & \begin{array}{c}\text { Date } \\ 06 / 09 / 1989\end{array} & \begin{array}{c}\text { Date } \\ 06 / 08 / 1990\end{array} \\ \text { SAF } & 05 / 15 / 1987 & 05 / 14 / 1990\end{array}$

Stand-By

$05 / 15 / 1987$

$05 / 14 / 1988$

\author{
SDR Million \\ 291.00 \\ 448.11
}

SDR Million
86.31

SDR Million

126.83

7.63

22.65

142.91

Amount Approved (SDR Million)

116.40

203.70

100.00

$$
\begin{gathered}
\text { \%Quota } \\
100.0 \\
154.0
\end{gathered}
$$
\%Allocation 100.0
\%Quota
43.6
2.6
7.8

49.1

VI. Projected Obligations to Fund ${ }^{1}$ (SDR Million; based on existing use of resources and present holdings of SDRs):

\begin{tabular}{lcccccc} 
& Overdue & & \multicolumn{5}{c}{ Forthcoming } \\
\cline { 3 - 7 } & & & & & & \\
Principal & $\mathbf{0 4 / 3 0 / 2 0 0 1}$ & $\mathbf{2 0 0 1}$ & $\mathbf{2 0 0 2}$ & $\mathbf{2 0 0 3}$ & $\mathbf{2 0 0 4}$ & $\mathbf{2 0 0 5}$ \\
Charges/interest & 300.0 & 0.0 & 0.0 & 0.0 & 0.0 & 0.0 \\
Total & 91.8 & 9.2 & 11.8 & 11.8 & 11.8 & 11.8 \\
& 391.8 & 9.2 & 11.8 & 11.8 & 11.8 & 11.8
\end{tabular}

${ }^{1}$ The projection of charges and interest assumes that overdue principal at the report date (if any) will remain outstanding, but forthcoming obligations will be settled on time. 


\section{Exchange Rate Arrangement:}

The Democratic Republic of the Congo's currency is the Congo franc (CGF), which, since May 26, 2001, has been freely floating. On June 1, 2001, the rate was US\$1=CGF 349.91. From July 1, 1998, through May 25, 2001, a multiple exchange rate system was in effect, implying an official rate, the most recent one being US $\$ 1=\mathrm{CGF} 50$, and a rate determined in the parallel market.

\section{Last Article IV Consultation:}

(a) Consultations with the Democratic Republic of the Congo are on the standard 12month cycle.

(b) The last Article IV consultation was concluded by the Executive Board on March 1, 1996 (SM/96/34; 2/7/96).

\section{Technical Assistance:}

\section{Subject}

Monetary Statistics

Exchange Rate System

Tax Administration/Policy

\section{Department Staff Member Date}

STA

Mr. Papadacci

Ms. Tanase

MAE

Mr. Bussers

May 9-14, 2001

FAD

Mr. Corfmat

May 11-21, 2001

Mr. Fossat

\section{Resident Representative:}

None 


\section{Democratic Republic of the Congo: Relations with the World Bank Group \\ (As of June 2001)}

The World Bank suspended processing of new operations in 1990 and disbursements in 1993. The Democratic Republic of the Congo (DRC) is in nonaccrual status with arrears of over US\$300 million (IBRD and IDA). Following a mission in March 1998, the World Bank prepared a Country Economic Memorandum to provide a starting point for discussing options for sustainable growth and improving living conditions. An August 1998 mission was cut short by the start of the armed conflict.

In November 1999, a World Bank-led multidonor/multiagency mission visited the country to help reopen the dialogue with the international financial and donor community. Since then, several other visits have taken place, some jointly with other partners.

The World Bank is providing a wide range of technical assistance, some funded by trust funds, the Institutional Development Fund (IDF) and the Post Conflict Fund (PCF). Sectors/activities covered include, among others, mining, audits of commercial banks, transport policy, and demobilization of children and soldiers.

Emergency Fund: The Emergency Stabilization Recovery Project is funded via a multi-donor trust fund administered by the World Bank, with an initial balance of US\$5 million. It is designed to provide assistance to the country to help tackle the worst aspects of poverty via mostly small projects in the health, education, agriculture, water, and infrastructure rehabilitation sectors. Project documents were signed by the World Bank and the Government in October 2000, and the Government has fulfilled most effectiveness conditions.

Mining Sector: The World Bank is supporting the mining sector through a recently closed IDF grant resulting in the elaboration of a draft mining code. A follow-up mining IDF grant was recently approved in the amount of US $\$ 428,000$ and will finance activities to finalize the draft mining code and the establishment of a mining cadastre.

Transport Sector: In 2000, the World Bank approved a US $\$ 500,000$ IDF grant for Technical Assistance to the Ministry of Transport and Communications for the Elaboration of a Transport Policy Framework and Action Plan. The activities funded by this grant are proceeding satisfactorily.

Demobilization: A PCF grant for a total of US\$2 million has been approved by the World Bank to help prepare a program of demobilization of child and vulnerable soldiers. A first tranche of US $\$ 700,000$ is currently being implemented by the ILO to conduct demobilization studies. Activities to be financed under the second tranche of US $\$ 1.3$ million are currently being prepared. 
Reintegration of Street Children: A PCF grant of US\$1 million was approved in May 2001, for the reintegration of street children in urban areas. Execution arrangements through an international NGO are being finalized and the grant will become effective in July 2001. A co-financing grant of an additional US\$1 million has been requested from the Japan Post Conflict Fund.

Other PCF grants are currently being prepared and will be submitted to the PCF committee in late July 2001. These include among others:

- Pilot activities for the Rapid Assessment Community Survey (RACS) to measure living and infrastructure conditions (US $\$ 300,000$ ). The objective of this grant is to prepare an upcoming RACS planned under the IDA grant by : (i) taking stock of existing data; (ii) preparing an information needs assessment and identifying information gaps; (iii) conducting a feasibility study to identify the methodologies and partners in the field to conduct the survey exercise; (iv) based on the needs assessment, preparing a survey questionnaire and training manuals; and $(v)$ conducting a field test to finalize the questionnaire and training a core group of key counterparts to be later used as trainers for the larger exercise to be financed by the IDA Grant.

- Emergency re-launching of economic activities in the MONUC monitored zone (US\$1 million): jump-starting economic activity in areas recently vacated by belligerent armed groups including support to micro-credit schemes and financing of agricultural tools and bicycles.

- Food security in Kinshasa by supporting merchant and transport associations in Bas Congo, Bandundu, and Kinshasa Provinces (US\$700,000): co-financing of rehabilitation of rural roads and rural bridges in agricultural areas. Professional associations finance 15 percent, grants finance 85 percent.

- Emergency rehabilitation project in Kisangani (US\$1 million).

Public Enterprise Reform: Further assistance is being considered to help the DRC design a strategy for reform of the public enterprise sector.

Transitional Support Strategy: The World Bank is currently preparing a Transitional Support Strategy (TSS) to be presented to the Board in late July 2001, at the same time as a proposed grant under the IDA 12 window (see below). This TSS will outline World Bank activities (lending and non-lending) for the next 24 months.

IDA Grant: An IDA grant in the amount of US\$50 million is currently being prepared and is expected to be presented to the Board in late July 2001 , at the same time as the Transitional Support Strategy. This grant will provide critical support to key areas until normal financing can resume following clearance of arrears. The main areas to be supported are: institutional capacity building, HIV/AIDS, urgent repairs of key infrastructure, and possible financing of some emergency social expenditures. 
IFC

Arrears to IFC are about US $\$ 50$ million. Because of the arrears situation and the frozen lending relationship between the World Bank and the DRC, the IFC has put on hold its activities.

\section{MIGA}

Currently, MIGA is not in a position to issue guarantees for projects in the DRC because the country has not fully paid its capital subscription. In addition, it has arrears to, and is in non-accrual status with, the World Bank. MIGA does not have any exposure in the DRC, and has no active applications from the DRC. 


\section{Democratic Republic of the Congo: Statistical Issues}

Poor government, absence of technical assistance (associated with the country's arreats with the Fund), and civil strife and war have inflicted damage on administrative infrastructure and have resulted in loss of records and documents. Also, statistical surveys could not be conducted. Despite these difficulties, the DRC authorities continue to produce a vast array of statistics, most of which are contained in the annual report of the Banque Central du Congo (BCC). The BCC also issues a monthly Statistical Bulletin. The coverage and sectoral areas identified for improvement are described below. The authorities have requested that a Fund multitopic statistical mission visit Kinshasa in the near future.

A Fund fact-finding mission in real sector statistics visited Kinshasa in June 2001, with a view to making recommendations for improvements in the short and medium-run. A similar mission just returned from Kinshasa (see Government Finance section below). In both areas, technical assistance will need to be supported by capacity building, covering training, data processing and communications, but also (and foremost) basic needs as well (such as furniture and supplies, air conditioning, building repair, etc.).

\section{National accounts}

The aggregated national accounts are available in constant and current prices. They are produced by the Directorate of Research of the $\mathrm{BCC}$ and published on an annual basis. The methodology for preparing the national accounts conforms to the 1968 System of National Accounts (SNA) and is based on the balance sheets of enterprises and the results of surveys of public and semipublic enterprises and agencies. However, most of these surveys date back to the late 1980s. The activities of the traditional sector (including the informal sector) are also included, using extrapolation techniques based on industry-specific data. On average, the traditional sector accounts for more than 60 percent of GDP.

\section{Employment and unemployment}

Annual data on employment in the Central Government are available from the Ministry of Economy, Finance, and the Budget, together with employment in the formal sector.

\section{Prices}

Various consumer price indices are calculated for Kinshasa by the BCC, the Institute of Economic and Social Research (IESR), and the Economic Section of the US Embassy. The IESR also calculates a monthly consumer price index for the Lumumbashi markets. The household surveys on which these calculations are based date back to the late 1980s. 


\section{Government accounts}

The BCC produces monthly statistics on a cash basis based on information provided in part by the Treasury and in part from its own accounting records on the government cash operations it executes. Due to the absence of an integrated double entry public accounting system, these statistics do not include all government revenue, expenditure, and financing. Furthermore, they provide insufficient details about the nature of expenditure owing to problems in the expenditure chain.

During the fact-finding mission of June 2001, a work program for improvement was developed with and agreed to by the authorities. This program would consist of several visits by a peripatetic expert and would aim at producing a well-documented set of government finance statistics in a format common to Francophone countries in the region and familiar to Fund staff. A preliminary version of this presentation would be available in September or October 2001. The timing of further progress would however be constrained by the pace of reforms in the areas of accounting and budget execution.

\section{Monetary accounts}

The BCC Research Directorate regularly produces sets of monetary statistics. The reliability of these statistics has been improved following implementation of recommendations made by technical assistance missions in 1996 and 2000. Nevertheless, problems remain concerning the sectorization of the accounts. Also, extensive manual intervention (because of lack of computer equipment) negatively affects the quality of output.

However, since the last money and banking statistics mission in June 2000, only data for interest rates (through December 2000) have been reported by the $\mathrm{BCC}$, for IFS publication.

\section{Balance of payments}

The balance of payments is prepared on an annual basis, with a lag of at least six months, based on information on exports and imports of large public and semipublic enterprises, the BCC's payments records, and a survey of resident's foreign accounts operations. The official data are adjusted significantly, to take account of the informal sector. Data on foreign aid flows are provided by the local UNDP office, which collects them from the European union, embassies, and NGOs.

Given the various data sources, the balance of payments is compiled partly on a cash basis and partly on a transactions basis. Also, its almost complete mamual compilation makes it error prone. Because of fraud, the importance of the informal sector in economic activity and disintermediation, the balance of payments as currently prepared is of limited usefulness. 


\section{External and domestic debt}

External and domestic debt statistics are compiled by the Office de Gestion de la Dette Publique (OGEDEP) and are of reasonable quality for external debt, despite a virtual complete absence of computer equipment. However, domestic debt and, in particular, crossarrears in the public sector, is of very poor quality.

\section{Public enterprise sector}

There is no centralized comprehensive database on the operations of the public enterprises. However, some information is made available to Fund missions by individual enterprises. Data are on an annual basis and become available with at least a six-month delay. 
Democratic Republic of the Congo: Core Statistical Indicators

(As of May 31, 2001)

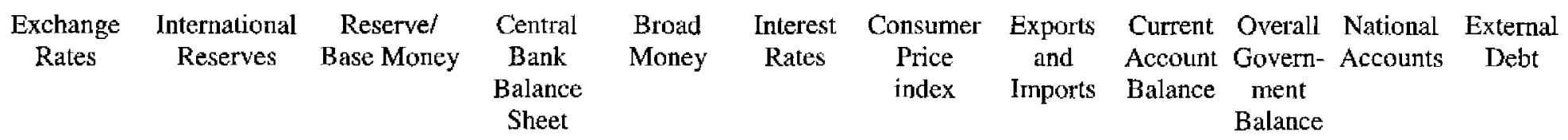

Date of latest observation

Date received

Frequency of data $1 /$

Frequency of

reporting $1 /$

Source of data $2 /$

Mode of reporting $3 /$

Confidentiality $4 /$

Frequency of publication $1 /$

\begin{tabular}{|l|l|l|l|l|l|l|l|l|l|l|l|}
\hline $5 / 28 / 01$ & $3 / 31 / 01$ & $3 / 31 / 01$ & $3 / 31 / 01$ & $3 / 31 / 01$ & $4 / 30 / 01$ & $4 / 30 / 01$ & 1999 & 1999 & 2000 & 2000 & 1999 \\
\hline $5 / 29 / 01$ & $5 / 2 / 01$ & $5 / 2 / 01$ & $5 / 2 / 01$ & $5 / 2 / 01$ & $5 / 2 / 01$ & $5 / 2 / 01$ & $2 / 12 / 01$ & $2 / 12 / 01$ & $2 / 12 / 01$ & $2 / 12 / 01$ & $2 / 12 / 01$ \\
\hline $\mathrm{D}$ & $\mathrm{M}$ & $\mathrm{M}$ & $\mathrm{M}$ & $\mathrm{M}$ & $\mathrm{O}$ & $\mathrm{M}$ & $\mathrm{A}$ & $\mathrm{A}$ & $\mathrm{Q}$ & $\mathrm{A}$ & $\mathrm{A}$ \\
\hline $\mathrm{D}$ & $\mathrm{M}$ & $\mathrm{M}$ & $\mathrm{M}$ & $\mathrm{M}$ & $\mathrm{O}$ & $\mathrm{M}$ & $\mathrm{V}$ & $\mathrm{V}$ & $\mathrm{Q}$ & $\mathrm{V}$ & $\mathrm{V}$ \\
\hline $\mathrm{N}$ & $\mathrm{A}$ & $\mathrm{A}$ & $\mathrm{A}$ & $\mathrm{A}$ & $\mathrm{A}$ & $\mathrm{A}$ & $\mathrm{A}$ & $\mathrm{A}$ & $\mathrm{A}$ & $\mathrm{A}$ & $\mathrm{A}$ \\
\hline $\mathrm{E}$ & $\mathrm{E}$ & $\mathrm{E}$ & $\mathrm{E}$ & $\mathrm{E}$ & $\mathrm{C}$ & $\mathrm{C}$ & $\mathrm{V}$ & $\mathrm{V}$ & $\mathrm{C}$ & $\mathrm{V}$ & $\mathrm{V}$ \\
\hline $\mathrm{C}$ & $\mathrm{A}$ & $\mathrm{A}$ & $\mathrm{A}$ & $\mathrm{A}$ & $\mathrm{A}$ & $\mathrm{A}$ & $\mathrm{A}$ & $\mathrm{A}$ & $\mathrm{A}$ & $\mathrm{A}$ & $\mathrm{A}$ \\
\hline $\mathrm{D}$ & $\mathrm{M}$ & $\mathrm{M}$ & $\mathrm{M}$ & $\mathrm{M}$ & $\mathrm{M}$ & $\mathrm{M}$ & $\mathrm{A}$ & $\mathrm{A}$ & $\mathrm{Q}$ & $\mathrm{A}$ & $\mathrm{A}$ \\
\hline
\end{tabular}

1/ Frequency of data, reporting, and publication: $D=$ daily, $W=$ weekly, $M=$ monthly, $Q=$ quarterly, or $A=$ annually.

2/ Source of data: A=direct reporting by central bank, Ministry of Finance, or other official agency, or $\mathrm{N}=$ official publication or press release.

3/ Mode of reporting: $\mathrm{E}=$ =lectronic data transfer, $\mathrm{C}=$ cable or facsimile, $\mathrm{T}=$ telephone, $\mathrm{M}=$ mail, $\mathrm{V}=\mathrm{staff}$ visits, or $\mathrm{O}=$ other.

4/ Confidentiality: $A=$ for use by staff only, $B=$ for use by the staff and the Executive Board, or $\mathrm{C}=$-for unrestricted use. 


\title{
INTERNATIONAL MONETARY FUND
}

\section{DEMOCRATIC REPUBLIC OF THE CONGO}

\section{Staff Report for the 2001 Article IV Consultation and Discussions on a Staff-Monitored Program}

\author{
Supplementary Information
}

\author{
Prepared by the African Department \\ In consultation with the Legal, Policy Development and Review, \\ and Treasurer's Departments \\ Approved by G. E. Gondwe and S. Kashiwagi
}

July 12, 2001

1. Available information through mid-June indicates that the authorities are rigorously implementing their economic program for the period June 2001-March 2002 that is being monitored by the Fund staff. ${ }^{1}$ All prior actions have been taken, with the exception of the adoption of the new statutes of the Central Bank of the Congo (BCC) (see Table 1). The new statutes of the $\mathrm{BCC}$, which would restore its independence, require an amendment to the Constitution which is expected to be adopted soon, with enactment of the new BCC statutes and the new banking law in the next few weeks. Strict adherence to the monthly treasury cash-flow plan has prompted a steep decline in inflation in June, as foreseen under the program.

2. In the first four months of 2001, the Congolese economy continued its downward slide. Output in agriculture, mining (with the exception of cobalt), and manufacturing declined as compared with the corresponding period of 2000 .

3. The cumulative rate of inflation, which amounted to 68 percent in the first four months of the year, jumped to about 130 percent for the January-May period, in line with an accelerated depreciation of the Congo franc (CGF) in the parallel market; the depreciation was partly related to speculation about imminent government action in the exchange rate area

\footnotetext{
${ }^{1}$ A staff team comprising Mr. Clément (Head) and Mr. Gons (both AFR) participated in a donors' information meeting in Paris on July 3, and subsequently visited Kinshasa to take stock of developments since the inception of the staff-monitored program. The authorities have so far broadly complied with the data reporting requirement listed in the Technical Memorandum of Understanding (TMU) (see EBS/01/94, Appendix I, Attachment II).
} 
in the context of the staff-monitored program (SMP). In June, the monthly rate of inflation decelerated noticeably to 2 percent, from about 36 percent in May. In fact, in the second half of the month the consumer price index, as prepared by the BCC, actually dropped (prices of certain basic items like rice, flour, and vegetables reportedly have declined). This trend continued in the first week of July.

4. In the fiscal area, information provided by the treasury shows that the accumulated cash deficit for January-May amounted to CGF 4.2 billion ( 0.4 percent of GDP), or about CGF 3.4 billion ( 0.3 percent of GDP) less than projected. In May, when the authorities started to effectively implement the monthly treasury cash-flow plan, a surplus of almost CGF 0.2 billion was recorded (against a projected deficit of CGF 2.0 billion) (Table 2). Consequently, net credit to government was negative for the first time in many years. Indications for June point to a surplus that may well exceed the programmed target of CGF 30 million, despite an unforeseen cash bonus of CGF 250 million (1.2 percent of the programmed wage bill for 2001) given to the military on Independence Day, June 30.

5. In the foreign exchange market, after an initial depreciation to about US $\$ 1=$ CGF 350 following the announcement of the new floating exchange rate system on May 26, 2001, the Congo franc appreciated in late June/early July to about US $\$ 1=$ CGF 300 (see Figure 1). The difference between the exchange rate quoted by the foreign exchange bureaus and the commercial banks is minimal.

6. Concerning economic security, the law creating commercial courts was adopted by Parliament early July 2001.

7. During the donors' information meeting on the Democratic Republic of the Congo (DRC) held in Paris on July 3, 2001, participants congratulated the authorities for the bold and courageous measures included in their program monitored by the Fund staff. In general, participants agreed to support the DRC's efforts, including in the very short term. Progress toward peace, the inter-Congolese dialogue, and macroeconomic stability were seen as three intertwined objectives. In addition to the US $\$ 280$ million in ongoing projects (mostly in the form of humanitarian aid), participants indicated their intention to provide additional assistance of US $\$ 240$ million (including US $\$ 50$ million in IDA grants). The assistance will finance, inter alia, a list of strategic projects amounting to US\$156 million, developed with World Bank assistance, to address in particular supply bottlenecks, administrative capacity, and social hardship. Upon approval by the World Bank Board of the IDA grant, quickdisbursing projects are envisaged to begin as early as August 2001. Another donors' meeting is envisaged before the end of this year to take stock of the situation in the DRC and of the support of the international community.

8. The authorities have deposited SDR 100,000 in their account at the Bank for International Settlements. They intend to make a second deposit of this magnitude before July 13, 2001. 
Figure 1. Democratic Republic of the Congo: Evolution of the Exchange Rate Following the Implementation of a

Floating Exchange Rate System on May 26, 2001.

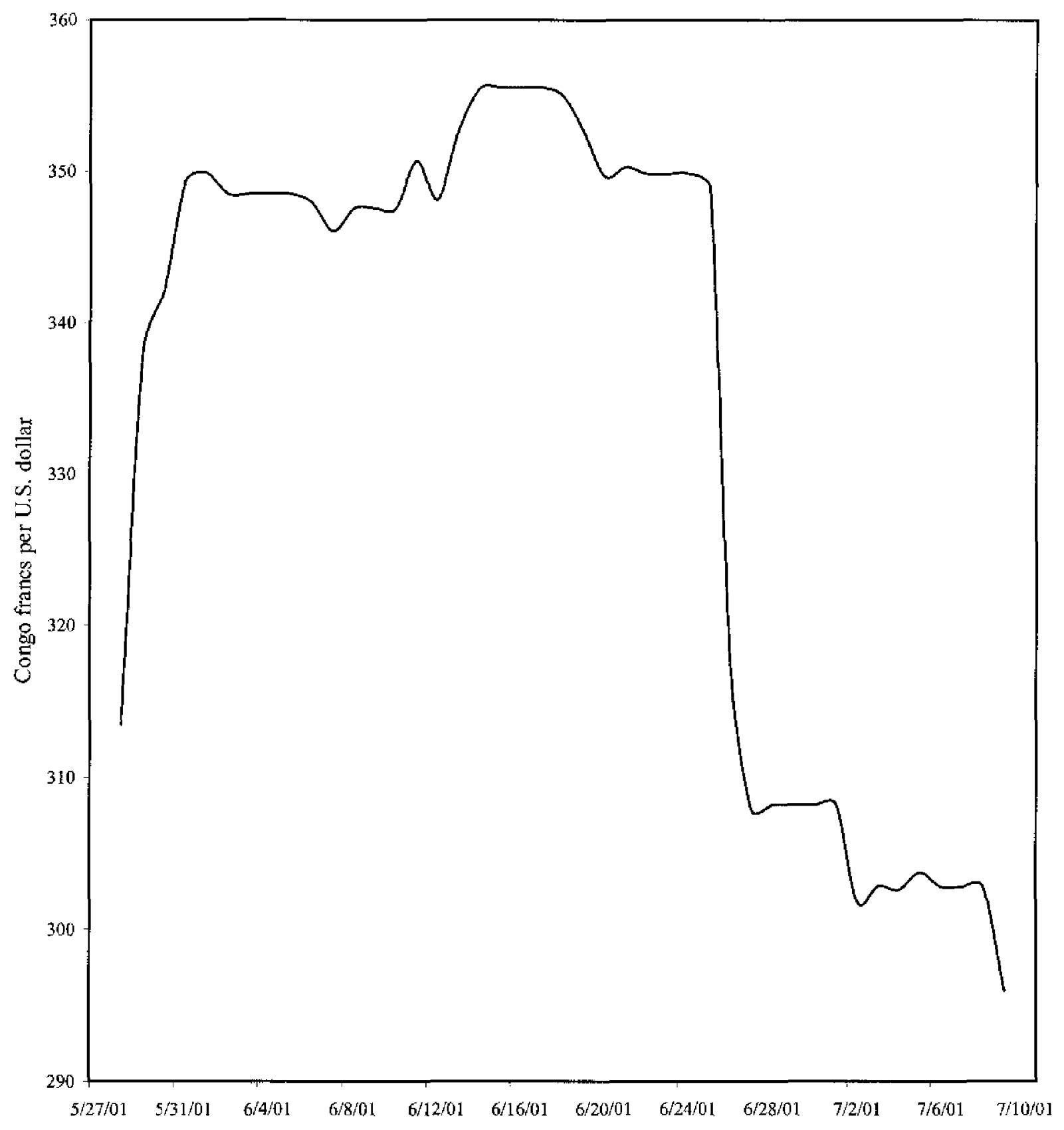

Source: Congolese Authorities 
Table 1. Democratic Republic of the Congo: Prior Actions 1/

\section{Government finance}

\section{Status}

Start execution of the 2001 budget strictly on a cash basis.

Executed

Centralize expenditure and eliminate all extrabudgetary expenditure.

Ongoing

Deposit all revenue in the treasury's general account with the BCC.

Ongoing

Finalize the list of priority strategic projects for 2001 with the World Bank.

Executed

\section{Monetary sector}

Enact and publish all legislation on the independence of the BCC, as well as the new banking law (taking

Pending $2 /$ due account of the comments of the IMF) by end-June 2001 .

Liberalize all interest rates.

Executed

Ensure that the BCC will no longer extend direct credit to the private sector or to public enterprises.

Moreover, any transaction on account of the government will require the authorization of the Minister of

Executed

Economy, Finance, and the Budget.

In coordination with the Minister of Economy, Finance, and Budget, reconcile the accounts that constitute net credit to the government.

Begin strengthening the supervision of the banking system.

\section{External sector}

Introduce a floating exchange rate system and publish related legislation and regulations, taking due account of IMF comments.

\section{Structural measures}

Enhance interministerial coordination on economic and financial policies through ECOFIN.

Effectively liberalize the diamond market and publish applicable legislation.

Executed

Cease all arbitrary interference and involvement in commercial activities.

Ongoing

Liberalize the prices of goods by end-June 2001, with the exception of electricity, water, and public

Executed transportation, which will be adjusted periodically.

Liberalize petroleum product prices and establish an automatic and transparent mechanism for pricing

Executed petroleum products. Raise the prices of petroleum products in accordance with that mechanism.

1/ See EBS/01/94 (6/22/01), Appendix I, Attachment I, Table 3.

2/ Adoption of the new statutes of the $\mathrm{BCC}$ requires an amendment to the Constitution to allow for the independence of the BCC. Publication of the new banking law has also been delayed because there is a need to harmonize this legislation with the statutes of the BCC. Both pieces of legislation will be published at the same time in the next few weeks. 
Table 2. Democratic Republic of the Congo: Monthly Treasury Casb-Flow Plan, January-May 2001

(In millions of Congo francs)

\begin{tabular}{|c|c|c|c|c|c|}
\hline & $\begin{array}{c}\text { May } \\
\text { (EBS/01/94) }\end{array}$ & $\begin{array}{l}\text { May } \\
\text { Est. }\end{array}$ & $\begin{array}{c}\text { Jan. - May } \\
\text { LBS/01/94 } \\
(1)\end{array}$ & $\begin{array}{c}\text { Jan. - May } \\
\text { Est. } \\
(2)\end{array}$ & $\begin{array}{l}\text { Difference } \\
\text { (2)-(1) }\end{array}$ \\
\hline Total revenue and grants & 4,146 & 4,673 & 14,966 & 15,332 & 366 \\
\hline Total revenue & 4,146 & 4,673 & 14,966 & 15,332 & 366 \\
\hline Customs and excisc (OFIDA) & 2,069 & 2,168 & 6,105 & 6,204 & 99 \\
\hline Direct and indirect taxes (DGC) & 868 & 1,258 & 3,926 & 4,317 & 390 \\
\hline DGRAD & 144 & 278 & 691 & 825 & 134 \\
\hline GECAMINES & 0 & 0 & 0 & 0 & 0 \\
\hline $\mathrm{M} B \mathrm{BA}$ & 0 & 95 & 5 & 100 & 95 \\
\hline Petroleum & 154 & 107 & 657 & 721 & 64 \\
\hline Other & 182 & 38 & 685 & 269 & -416 \\
\hline Off-budget revenue & 729 & 729 & 2,896 & 2,896 & 0 \\
\hline Total grants & 0 & 0 & 0 & 0 & 0 \\
\hline Total expenditure & 6,170 & 4,506 & 22,576 & $19,5: 7$ & $-3,059$ \\
\hline Current expenditure & 4,270 & 3,593 & 17,761 & 15,689 & $-2,072$ \\
\hline Wages & 2,033 & 1,835 & 6,649 & 5,826 & -823 \\
\hline Military & $\cdots$ & $\cdots$ & $\ldots$ & $\cdots$ & $\cdots$ \\
\hline Civilians & $\cdots$ & $\ldots$ & $\ldots$ & $\ldots$ & $\ldots$ \\
\hline Interest payments & 69 & 25 & 131 & 87 & -44 \\
\hline Extenal debt (payment) & 0 & 0 & 0 & 0 & 0 \\
\hline Domestic deot (payment) & 69 & 25 & 131 & 87 & -44 \\
\hline Other current expenditure & 1,368 & 1,323 & 7,960 & 7,804 & -155 \\
\hline Institutions & 500 & 219 & $2,27 \mathrm{I}$ & 1,850 & -421 \\
\hline Ministries & 650 & 288 & 3,309 & 2,958 & -352 \\
\hline Centralized payment (utilities) & 100 & 28 & 365 & 293 & -72 \\
\hline Province & 100 & 383 & 837 & 1,120 & 283 \\
\hline Other & 18 & 405 & 1,178 & 1,584 & 406 \\
\hline Transfers and subsidies & 800 & 410 & 3,021 & 1,972 & $-1,049$ \\
\hline Petroleum Guarantee Fund & 400 & 0 & 400 & 0 & -400 \\
\hline Off-budget expenditure & 729 & 729 & 2,896 & 2,896 & 0 \\
\hline Capital expenditure & 310 & 43 & 1,057 & 790 & -267 \\
\hline Other operations & 161 & 141 & 161 & 141 & -20 \\
\hline Contingency Fund & 300 & 0 & 300 & 0 & -300 \\
\hline Change in arrears & $\ldots$ & $\ldots$ & $\cdots$ & $\ldots$ & $\ldots$ \\
\hline Monthly balance (cash basis) & $-2,024$ & 167 & $-7,610$ & $-4,185$ & 3,425 \\
\hline Cumulated balance (cash basis) & $-7,610$ & $-4,185$ & $-7,610$ & $-4,185$ & 3,425 \\
\hline Total bank financing $1 /$ & 2,024 & -167 & 7,610 & 4,185 & $-3,425$ \\
\hline Treasury bills & 255 & 19 & 830 & 594 & -236 \\
\hline $\mathrm{BCC}$ and other banking system & $\mathrm{I}, 769$ & $-1,113$ & 6,780 & 2,327 & $-4,453$ \\
\hline Discrepancy & $\ldots$ & 926 & 0 & 1,264 & 1,264 \\
\hline
\end{tabular}

Sources: Congolese authorities; and stuff estimates (see EBS/01/94, 6/22/01, Appendix I, Attachment I, Table 7).

1/ A commission was created in May 2001 to reconcile the gap between net credit to the government as tecorded in the monetary sutvey and as recotded in the treasury accounts. 
Table 3. Democratic Republic of the Congo: Monetary Programming, 2000-01 (In millions of Congo francs)

\begin{tabular}{|c|c|c|c|c|c|c|}
\hline & \multicolumn{2}{|c|}{ December 2000} & \multicolumn{3}{|c|}{ May 2001} & \multirow{2}{*}{$\begin{array}{l}\text { May } 2001 \\
\text { (EBS/01/94) }\end{array}$} \\
\hline & $\begin{array}{l}\text { Estimate in } \\
\text { May } 2001\end{array}$ & $\begin{array}{l}\text { Revised estimate } \\
\text { in July } 2001\end{array}$ & $\begin{array}{c}\text { Including } \\
\text { exchange rate } \\
\text { adjustment effect } \\
\text { (1) }\end{array}$ & $\begin{array}{l}\text { Exchange rate } \\
\text { adjustment offect } \\
\text { (2) }\end{array}$ & $\begin{array}{c}\text { Excluding } \\
\text { exchange rate } \\
\text { adjustment effect } \\
(3)=(1)-(2)\end{array}$ & \\
\hline Net foreign assets & $-23,045$ & $-23,078$ & $-128,245$ & $-109,888$ & $-18,358$ & $-22,179$ \\
\hline Net domestic assets & 18,353 & 18,353 & 26,821 & 4,275 & 22,545 & 28,545 \\
\hline Net credit to govemment $1 /$ & 15,404 & 15,404 & 18,326 & 0 & 18,326 & 23,014 \\
\hline Credit to the private sector & 2,539 & 2,539 & 5,973 & 2,414 & 3,559 & 4,927 \\
\hline Credit to the parastatals & 409 & 409 & 2,522 & 1,861 & 661 & 603 \\
\hline Broad money (M2) & 22,004 & 22,004 & 54,183 & 19,319 & 34,863 & 30,587 \\
\hline Narrow money (M1) & 19,373 & 18,557 & 30,833 & 0 & 30,833 & 27,130 \\
\hline Currency in circulation & 15,963 & 15,963 & 26,483 & 0 & 26,483 & 22,514 \\
\hline Demand deposits & 3,410 & 2,594 & 4,351 & 0 & 4,351 & 4,616 \\
\hline Quasi money & 2,631 & 3,447 & 23,350 & 19,319 & 4,030 & 3,457 \\
\hline Time deposits in domestic currency & 0 & 0 & 19 & 0 & 19 & 5 \\
\hline Foreign currency deposits & 2,630 & 3,446 & 23,331 & 19,319 & 4,011 & 3,452 \\
\hline Import deposits & 1,554 & 1,554 & 9,564 & 7,958 & 1,607 & 1,713 \\
\hline Other items, net (iacluding valuation change) & $-28,250$ & $-28,283$ & $-165,172$ & $-132,890$ & $-32,282$ & $-30,280$ \\
\hline
\end{tabular}

Sources: Congolese authorities; and staff estimates (see EBS/01/94, 6/22/01, Appendix I, Attachment I, Table 6).

1/ A commission was created in May 2001 to reconcile the gap between net credit to the govennment as recorded in the monetary survey and as recorded in the treasury accounts. 


\section{INTERNATIONAL MONETARY FUND}

Public Information Notice

EXTERNAL

RELATIONS

DEPARTMENT

Public Information Notice (PIN) No. 01/70

FOR IMMEDIATE RELEASE

July 20,2001
International Monetary Fund

$70019^{\text {th }}$ Street, NW

Washington, D. C. 20431 USA

\section{IMF Concludes Article IV Consultation with the Democratic Republic of the Congo}

On July 13,2001 , the Executive Board of the International Monetary Fund (IMF) concluded the Article IV consultation with the Democratic Republic of the Congo (DRC). ${ }^{1}$

\section{Background}

Economic mismanagement, political turmoil, and a prolonged rundown in the economic and social infrastructure since the early 1990 s, combined with the effects of the war that erupted in August 1998 , have created a vicious circle of hyperinflation, continued depreciation of the currency, increasing dollarization, financial disintermediation, lack of saving, falling output, and generalized impoverishment of the population with the concomitant spread of diseases like HIVIAIDS.

In this context, output is well below 1990 levels and per capita real GDP has plummeted from US $\$ 224$ in 1990 to US $\$ 85$ in 2000 (or 23 cents a day). Over the past three years alone, real GDP has fallen by 5 percent per year on average, while consumer prices rose at an annual average rate of 107 percent in 1998, 270 percent in 1999, and 554 percent in 2000 . In the first four months of 2001, consumer prices rose by another cumulative 68 percent. The gap between the official and parallel exchange rates widened from 44 percent at end 1998 to 545 percent in mid-May 2001. Gross international reserves stood at the equivalent of only 2.2 weeks of imports of goods and nonfactor services at end-2000. External debt rose to 280 percent (or almost US $\$ 13$ billion) of GDP at end-2000, with arrears accounting for about

\footnotetext{
'Under Article IV of the IMF's Articles of Agreement, the IMF holds bilateral discussions with members, usually every year. A staff team visits the country, collects economic and financial information, and discusses with officials the country's economic developments and policies. On return to headquarters, the staff prepares a report, which forms the basis for discussion by the Executive Board. At the conclusion of the discussion, the Managing Director, as Chairman of the Board, summarizes the views of Executive Directors, and this summary is transmitted to the country's authorities. This PIN summarizes the views of the Executive Board as expressed during the July 13, 2001 Executive Board discussion based on the staff report.
} 
75 percent of the total. Multiple exchange rates and controls on prices have resulted in significant distortions in relative prices, and in shortages of basic items as well as petroleum products. The regulatory framework has become heavy, lacks transparency, and has been applied arbitrarily, which has resulted in a climate of suspicion and economic insecurity that has discouraged investment. Poor maintenance has led to rundown infrastructure and productive capacity.

Under the new President, Joseph Kabila, the political and security situation in the DRC has been improving since early 2001, thanks to the reactivation of the Lusaka cease fire agreement, involvement of the United Nations, and the enhancement of the inter-Congolese dialogue. A new reform-minded government was appointed on April 14, 2001, and on May 18,2001 , a presidential decree was signed liberalizing political activities.

In addition, the authorities have started the process of liberalizing, restructuring, and revitalizing the Congolese economy, especially the private sector. In this context, understandings have been reached on an economic program covering the period June 2001March 2002 that will be monitored by the staff of the IMF.

To address the alarming economic, financial and social situation, the authorities' program contains a critical mass of bold and front-loaded adjustment measures, aiming principally at breaking hyperinflation, stabilizing the economic situation, laying the foundation for a restoration of growth and reconstruction, and reducing poverty. To achieve these objectives, the macroeconomic policies envisaged in the program include, inter alia:

- A restrained budgetary policy, centered around strict adherence to a monthly treasury cash plan;

- A prudent monetary policy consistent with the objective of breaking hyperinflation. Central to the successful implementation of monetary policy will be the restoration of the independence of the Central Bank of the Congo (BCC);

- The implementation of a floating exchange rate system. On May 26, 2001, the new system was put in place, thereby unifying the existing official and parallel market rates.

Far reaching reforms in the structural area would significantly reduce price distortions, strengthen the banking sector, restore economic security, and liberalize the economy.

\section{Executive Board Assessment}

Executive Directors welcomed the improvement in the political and security situation since early 2001 as a result of the reactivation of the Lusaka cease-fire agreement, the involvement of the United Nations, and the enhancement of inter-Congolese dialogue. Directors considered that the resumption of economic growth will depend critically on continued progress toward peace. In that regard, they called on all parties involved to strongly and fully implement the Lusaka agreement with the assistance of the international community. 
Directors acknowledged the gravity of the DRC's situation, which is characterized by a vicious circle of hyperinflation, currency depreciation, financial disintermediation, falling production, and deteriorating infrastructure. Also, there is an alarming spread of epidemics, such as HIV/AIDS, and poverty is widespread.

Directors were of the view that the primary source of hyperinflation has been the monetization of uncontrolled budgetary deficits, stemming from the collapse of expenditure control and of fiscal revenues. Problems of governance, numerous tax exemptions, and significant extrabudgetary spending have contributed to this situation.

Directors commended the new authorities' interim program of bold and front-loaded adjustment measures to address this difficult situation, and welcomed its monitoring by the Fund staff. The program aims to break hyperinflation, liberalize the economy, and lay the foundation for reconstruction and growth. Directors considered that, if adhered to, the program will represent a clear break with the past, although they recognized that its implementation would represent a very great challenge.

Directors stressed that achieving the program's targets calls for strong fiscal adjustment, tight monetary policy, and well-sequenced structural and sectoral reforms. Successful implementation will depend on the timely strengthening of administrative capacity, for which the DRC will need support, including well-coordinated technical assistance, from the international community. Directors commended the authorities for the measures taken to date. These include the adoption of a floating exchange rate regime, the introduction of a monthly treasury cash flow plan, and strengthened coordination of government actions through the inter-ministerial committee (ECOFIN).

Directors urged the authorities to strictly implement the treasury cash flow plan, to centralize all receipts and expenditures at the treasury, and eliminate off-budget transactions. They encouraged making full use of the recommendations of the Fund's technical assistance on revenue and expenditure management. Directors also looked forward to the census that will review the size and structure of the civil service, as containment of the wage bill will be key to restoring a viable budget.

Directors agreed that strict limitation on advances by the $\mathrm{BCC}$ to the government will be crucial to achieving price stability. They stressed the need for the $\mathrm{BCC}$ to regain its independence in the conduct of monetary policy, and in this regard welcomed its forthcoming new statutes, as well as the intention to have its accounts audited by an internationally recognized firm.

Directors also welcomed the forthcoming new banking law that will strengthen the supervision of the banking system. They encouraged the authorities to pursue the audits of all commercia: banks in a timely manner with the help of the international community and, in particular, the World Bank. 
Directors noted that the new exchange rate system has de facto eliminated multiple exchange rate practices, and looked forward to the authorities' acceptance of the obligations of Article VIII in 2002. Directors also welcomed the liberalization of the diamond sector and the introduction of certification of diamonds to establish their origin.

Directors commended the authorities for their commitment to price liberalization, their implementation of a transparent and automatic mechanism for setting the prices of petroleum products, and having raised these prices to market levels. They looked forward to the mining and investment codes and the reform of the public enterprises, which will be prepared with World Bank assistance.

Directors stressed that the economic recovery calls for a transparent legal and regulatory environment, as well as economic security and good governance. They welcomed plans to empower commercial courts with the sole authority to settle disputes involving economic and financial matters. Directors also looked forward to the action plan to tackle pervasive corruption in the public sector. They encouraged the authorities to improve, with the help of the international community, macroeconomic and social statistics.

Overall, Directors considered that the Fund staff-monitored program (SMP) represents an ambitious effort by the authorities to address the difficult economic and social situation in the DRC. It deserves the timely support of the international community, through technical assistance and through highly concessional aid to finance, in particular, strategic projects selected with the help of the World Bank to relieve supply bottlenecks and social hardship. Early indications from donors in this respect were warmly welcomed.

Directors were of the view that the SMP, if implemented forcefully, will create the basis for a normalization of relations with the Fund and other international creditors. They considered that a strong track record under the SMP would help lay the foundation for a successor program supported by a PRGF arrangement, and pave the way for debt relief under the enhanced HIPC Initiative. In order to establish the basis for a successful PRGF-supported program, Directors noted the need to develop a poverty reduction strategy, improve governance, build institutional capacity, and garner the support of the international community. Many Directors noted that, given the size of the tasks and the DRC's unpropitious circumstances, it could take some time to satisfy these conditions.

Public Information Notices (PINs) are issued, (i) at the request of a member country, following the conclusion of the Article IV consultation for countries seeking to make known the views of the IMF to the public. This action is intended to strengthen IMF surveillance over the economic policies of member countries by increasing the transparency of the IMF's assessment of these policies; and (ii) following policy discussions in the Executive Board at the decision of the Board. 
Democratic Republic of the Congo: Selected Economic and Financial Indicators, 1997-2001

\begin{tabular}{|c|c|c|c|c|c|}
\hline & 1997 & 1998 & $\begin{array}{l}1999 \\
\text { Est. }\end{array}$ & $\begin{array}{l}2000 \\
\text { Est. }\end{array}$ & $\begin{array}{l}2001 \\
\text { Prog. }\end{array}$ \\
\hline & \multicolumn{5}{|c|}{ (Annual percentage changes) } \\
\hline \multicolumn{6}{|l|}{ Domestic Economy } \\
\hline Real GDP growth & -5.6 & -1.6 & -10.4 & -4.3 & 0.0 \\
\hline End-of-period CPI inflation & 14.0 & 135.0 & 484.0 & 511.0 & 99.0 \\
\hline Average CPI inflation & 199.0 & 107.0 & 270.0 & 554.0 & 299.0 \\
\hline & \multicolumn{5}{|c|}{ (In percent of GDP, unless otherwise indicated) } \\
\hline \multicolumn{6}{|l|}{ Financial variables } \\
\hline Total fiscal revenue (excluding grants) & 9.4 & 5.9 & 4.6 & 4.8 & 5.2 \\
\hline Total expenditure $1 /$ & 20.2 & 12.1 & 9.8 & 10.5 & 7.1 \\
\hline Overall balance (commitment basis) & -10.8 & -6.2 & -5.2 & -5.7 & -1.9 \\
\hline Overall balance (cash basis) & -6.3 & -2.7 & -3.5 & $-3,9$ & -0.3 \\
\hline Broad money (change in percent) & 71.1 & 160.0 & 382.0 & 493.1 & 53.3 \\
\hline \multicolumn{6}{|c|}{ (In millions of U.S. dollars, unless otherwise indicated) } \\
\hline External sector & & & & & \\
\hline Exports of goods and nonfactor scrvices & 1255.1 & 1240.3 & 1003.5 & 829.0 & 839.1 \\
\hline Imports of goods and nonfactor services & 1331.6 & 1368.9 & 1172.4 & 1224.3 & 1104.0 \\
\hline External current account (in percent of GDP) & -15.9 & -9.2 & -14.1 & -17.6 & -14.0 \\
\hline Real effective exchange rate $2 /$ & 22.7 & 3.9 & 168.8 & -22.3 & $\ldots$ \\
\hline
\end{tabular}

Sources: Congolese authorities; and IMF staff estimates and projections.

1/ lucluding interest duc on external debt.

2/ Annual avcrages based on official rates. Minus sign indicates depreciation. 


\section{Statement by Alexandre Barro Chambrier, Executive Director for the Democratic Republic of the Congo \\ July 13, 2001}

\section{INTRODUCTION}

For more than a decade, the Democratic Republic of the Congo has been facing a very difficult economic and financial situation, owing to the combination of adverse domestic and external factors, including severe economic mismanagement, political turmoil, and war in neighboring countries. These factors greatly contributed to the rundown in the economic and social infrastructure, of which one of the consequences was the accumulation of domestic and external arrears, including vis-à-vis the IMF. The latter ultimately led to the suspension in June 1994, of the DRC's voting and related rights. The impact of this difficult situation was compounded by the war that started in August 1998, leading to the plundering of the country's natural resources, as documented by the recent UN report, the occupation of a large portion of its territory by foreign armies, and further destruction of the social and economic fabric.

These developments have imposed tremendous suffering on the population, exacerbating poverty, in a country where it was already widespread and weakening further social indicators. Based on available information, more than three million people died during the war, and many more are left disabled. Sanitary and health conditions also deteriorated, leading to the increased spread of transmissible diseases like malaria, tuberculosis and HIV/AIDS.

The new President who took office in early 2001 has brought a new leadership, and put in place a strong team in charge of economic management. Available information indicate that, in a relatively short period, this team has been able to bring an encouraging reversal in trends on some financial indicators, particularly at the level of inflation and exchange rate. The authorities are determined to find lasting solutions to the country's woes, to end the war, and to fully normalize relationships with the international financial institutions, including the IMF. On the political front, the authorities are actively working towards the implementation of the Lusaka peace agreement, signed in August 1999, and the beginning of the inter-Congolese dialogue. On the economic front, they have started to take bold actions aim at stabilizing the economic situation, and restoring conditions for the revival of the economic activities. In this context, the staff-monitored program is an important first step, and my Congolese authorities are committed to implementing it in a way that will help them build a track record with the aim of enabling the Democratic Republic of the Congo to access Fund resources under the Poverty Reduction and Growth Facility (PRGF), and later qualify for assistance under the Heavily Indebted Poor Countries (HIPC) initiative, in order to bring its heavy debt burden to sustainable levels, and increase pro-poor outlays.

My authorities are in broad agreement with the staff appraisal and concur with the thrust of policy recommendations by the staff. They are cognizant of the need to clear 
arrears to the Fund and to establish a strong track record under the SMP. Despite a very difficult situation, they have started making deposits to the special account in June 2001, as agreed with Fund staff and initiated program implementation.

Today, the authorities are facing cnormous challenges in every single area, and I believe that current developments provide a window of opportunity for the international community to help the DRC resume normal relationships with the international community, and put its economy on a sustained growth path. In this context, financial as well as technical assistance is needed urgently to support the authorities' efforts towards restoring political and economic stability, and rebuilding the country.

\section{RECENT ECONOMIC DEVELOPMENTS}

The current economic situation should be assessed against the background of the internal difficulties that the country experienced since the early 1990s. Economic mismanagement, political turmoil and a prolonged deterioration in social and infrastructure, associated with the effects of the war that erupted in August 1998, have brought massive destruction to the country.

Real Growth has been declining continuously and the economic situation has been marked by hyperinflation, originating mainly from the unbridled monetization of a fiscal deficit that has so far proved uncontrollable. Moreover, hyperinflation has had a negative impact on saving, investment, output and real wages.

In the fiscal area, revenue have been weak for many years, while war-related expenditure, lack of transparency, and governance problems have aggravated the already weak fiscal situation. In absence of external assistance, except for humanitarian purposes, the drying up of external financing led to the constant monetization of fiscal deficits.

This situation has also led to a breakdown of financial intermediation, continued depreciation of the currency, increased dollarization, and aggravated the decline in fiscal revenue. Gross external reserves stood at only 2.2 weeks of imports of goods and nonfactor services at end-2000. At 280 percent of GDP at end-2000, the external debt remains heavy and arrears represent about 75 percent of the total public debt.

\section{Fiscal Policy}

To address the difficult fiscal situation, the program contains a number of revenueenhancing and expenditure-restraining in the 2001 budget. However, in the short-term, the focus will be on the improvement of fiscal management, with a monthily treasury cash-flow 
plan, that was put in place in June 2001. The plan will ensure that monthly expenditures do not exceed fiscal receipts. All expenditures and revenues will be centralized at the treasury, leading to the elimination of all off-budget receipts and expenditures. In addition, the BCC will no longer assume responsibility for executing payment orders that have not been issued by the Treasury.

On the revenue side, the authorities' efforts will aim at improving the revenue performance. To this end, they have taken a number of measures, which include: the centralization and depositing of all receipts in the Treasury's account at the Central Bank of Congo (BCC); the reduction of tax exemptions; the setting of monthly revenue performance targets for the Customs Directorate (OFIDA) and the Directorate General of Taxes (DGC); the abolition of the system of offsetting between enterprises and government entities; the elimination of any possibility of deferred tax payments; a decision to create a large taxpayers' unit; and the assessment of import duties on the basis of the CIF value of imports, calculated at the market exchange rate published by the BCC. It is also their intention to take before end-2001 measures defining the stages leading up to the simplification of taxation system on imports, defining a plan to replace the current turnover tax with a value-added tax in early 2003 , and conducting an evaluation to assess tax payment and revenue collection procedures.

On the expenditure side, the authorities are determined to ensure transparency in the expenditure process, to strengthen the monitoring and control of expenditure and prevent overruns. Subsidies to the public enterprises will be sharply reduced, with the view to eliminating them when the public enterprise reform plan is completed. Strict control will be maintained on the wage bill in 2001. As a result, civil service salaries, including those of military and police, will not increase during the program period. Military pay will be included into the regular wages roster. A civil service census is expected to be finalized by end-2001, and pending its completion, new hiring and replacement of retiring civil servants have been frozen, except for the education, and health sectors, and the rehabilitation of infrastructure. To allocate sufficient resources to the social sectors and the basic infrastructure, nonwage spending, sovereign expenditures, costs of mission abroad and the expenditures of the provinces will be strictly limited and controlled. With regard to capital expenditures, the authorities have agreed to limit them to strategic projects selected in cooperation with the World Bank. 


\section{MONETARY AND EXCHANGE RATE POLICIES}

The main objective of monetary policy is price stabilization. To this end, the BCC advances to the treasury will be limited in conformity with the monetary program. Furthermore, interest rates have been deregulated, and the $\mathrm{BCC}$ was granted decision-making autonomy with respect to its monetary policy and the use of its instruments.

The authorities are determined to implement financial policies in a sound manner, in order to restore confidence in the currency and end vicious circle of hyperinflation and currency depreciation. They are also committed to letting market forces play their role, and put in place a floating exchange rate system on May 26, 2001. In the same context, they lifted the measure restricting the holding of foreign currency in the country.

\section{STRUCTURAL AND SECTORAL REFORMS}

On structural reforms and Sectoral policies, the focus will be on enhancing governance and transparency and reinforcing legal and regulatory frameworks, in order to promote private sector participation and boost economic growth. The authorities introduced in May 2001, a transparent and automatic market-based pricing mechanism for petroleum products. The new system takes into account changes in international oil prices, operating costs, and the exchange rate. In the mining sector, a more competitive environment was created for the diamond sector, allowing new buyers to operate in the sector. Certification requirements in line with recent UN resolutions will be introduced. New investment and mining codes are being prepared, with assistance from the World Bank.

\section{Conclusion}

My authorities are determined to bring tangible changes in the country through sustainable solutions on the political and economic fronts. They are facing enormous challenges and operating under very difficult conditions in a country where the economic, social and infrastructure fabrics have been destroyed by years of mismanagement, plundering of resources, and war; all of which have imposed inhuman suffering on the population. They are committed to implementing measures contained in the program. However, they need the continuous help and support of the international community, to assist their reconciliation efforts in order to end the war, and also to support their economic stabilization efforts aimed at rebuilding the country. Finally, I would like to stress the fact that the restoration of peace and a strong economy in the DRC is also an important element for stability and economic development in the Great Lakes region. 